\title{
Caracterização das práticas educativas dos 'Agentes multiplicadores' do Projeto Nossas Crianças: Janelas de OPORTUNIDADES
}

Dissertação apresentada ao Programa de Pós-Graduação em Enfermagem da Escola de Enfermagem da USP - área de concentração Cuidado em Saúde - para obtenção do título de Mestre em Ciências

Orientadora: Profa. Dra. Anna Maria Chiesa 
AUTORIZO A REPRODUÇÃO TOTAL OU PARCIAL DESTE TRABALHO, POR QUALQUER MEIO CONVENCIONAL OU ELETRÔNICO, PARA FINS DE ESTUDO E PESQUISA, DESDE QUE CITADA A FONTE.

Assinatura: Data

Catalogação na Publicação (CIP)

Biblioteca "Wanda de Aguiar Horta"

Escola de Enfermagem da Universidade de São Paulo

Maricondi, Maria Angela

Caracterização das práticas educativas dos 'agentes multiplicadores' do Projeto Nossas Crianças: Janelas de Oportunidades / Maria Angela Maricondi - São Paulo, 2010. $183 \mathrm{p}$.

Dissertação (Mestrado) - Escola de Enfermagem da Universidade de São Paulo

Orientadora: Prof ${ }^{-a}{ }^{-a}{ }^{\text {a }}$ Anna Maria Chiesa

1. Educação em Saúde 2. Promoção da Saúde 3. Saúde da Criança I. Título 
FOLHA DE APROVAÇÃO

Autora: Maria Angela Maricondi

Orientadora: Profa. Dra. Anna Maria Chiesa

Título: Caracterização das práticas educativas dos 'agentes multiplicadores' do Projeto Nossas Crianças: Janelas de Oportunidades

Dissertação apresentada à Escola de Enfermagem da USP para obtenção do título de Mestre em Ciências

Aprovada em:

Profa. Dra. Instituição:

Julgamento: Assinatura:

Profa. Dra. Instituição:

Julgamento: Assinatura:

Profa. Dra. Instituição:

Julgamento: Assinatura: 
Agradecimentos

Às minhas queridas professoras com quem pude compartilhar conhecimentos, dúvidas e ansiedades, celebrando meus sucessos escolares e trocando experiências do nosso cotidiano profissional.

Aos meus queridos colegas que me fizeram sentir mais jovem do que de fato sou porque me acolheram como se eu fosse uma estudante universitária recém saída da graduação e dividiram comigo tudo o que tinham: suas angústias e conhecimentos, habilidades de computador, disposição para aprender, beber e festejar a vida!

À minha querida orientadora por ter 'puxado' esta empreitada em minha vida, o que me colocou frente a frente com novas $e$ interessantes perguntas.

Aos meus queridos amigos e amigas que me incentivaram, cada um à sua maneira.

Ao meu querido filho que sempre me salva na hora $H$ com sua criatividade de desenhista e paciência de quem sabe o que faz.

Ao meu querido companheiro que me cuida, canta para alegrar meu coração e enlevar minha alma, instiga meus pensamentos e me anima a continuar naqueles momentos tão conhecidos de desespero e vontade de largar tudo... 
Maricondi MA. Caracterização das práticas educativas dos 'agentes multiplicadores' do Projeto Nossas Crianças: Janelas de Oportunidades. [dissertação de mestrado]. São Paulo: Escola de Enfermagem da Universidade de São Paulo; 2010.

\section{Resumo}

Esta é uma pesquisa qualitativa de abordagem compreensiva que tem como objeto a caracterização das práticas educativas dos 'agentes multiplicadores' do Projeto Janelas, uma experiência de intervenção no âmbito da atenção básica/saúde da família ocorrida na cidade de São Paulo e voltada para a promoção do desenvolvimento infantil através do fortalecimento dos cuidados familiares para gestantes e crianças menores de seis anos. Objetivos: (1) descrever as práticas educativas dos profissionais com as equipes de saúde e as famílias; (2) identificar outras experiências de formação que influenciaram essas práticas; e (3) correlacionar as experiências relatadas com o processo de formação ocorrido no Projeto Janelas. Método: foi escolhida a história de vida tópica porque o objeto de estudo está circunscrito a uma determinada área de experiência dos sujeitos, neste caso, suas práticas educativas em saúde. As histórias, em número de seis, foram obtidas por meio de entrevistas combinando-se uma escuta aberta e atenta para a exploração e aprofundamento das experiências dos sujeitos e uma atitude diretiva para o levantamento de informações gerais e manutenção do foco da investigação. Resultados: no material coletado foram identificadas as categorias empíricas aspectos significativos da formação recebida; percepção de impacto nas próprias atitudes e condutas; abertura para a escuta; compreensão dos determinantes sociais do processo saúde-doença; práticas emancipatórias e regulatórias; práticas intersetoriais; fortalecimento dos cuidados familiares - que, na discussão, foram articuladas com as categorias analíticas - aprender a conhecer, aprender a fazer, aprender a conviver e aprender a ser; práxis dialógica; empoderamento psicológico e empoderamento comunitário; liberdade e autonomia; regulação e emancipação social. Os principais resultados referemse a aspectos da formação recebida, das práticas educativas desenvolvidas com as equipes e as famílias e à percepção de impacto dessas ações com as famílias. Conclusão: tanto a formação recebida quanto as práticas desenvolvidas caracterizam-se pela ampliação do olhar biomédico porque incluem aspectos emocionais e relacionais de indivíduos, grupos e famílias. Todos os sujeitos reconhecem e valorizam a abordagem crítico-participativa da formação que receberam, o impacto dela sobre determinadas atitudes e comportamentos (empoderamento dos profissionais), maior abertura para a escuta e algum tipo de transformação em suas práticas educativas no sentido do empoderamento da população. Quanto à incorporação de atitudes e práticas orientadas pelo respeito à autonomia da população (dialética regulaçãoemancipação), ela variou de sujeito para sujeito, com uma preponderância perceptível do pólo da emancipação social.

Descritores: Atenção Básica, Educação em Saúde, Promoção da Saúde, Saúde da Criança. 
Maricondi MA. Characterization of educational practices of the 'multiply agents' of Project Our Children: Windows of Opportunities. [Master's degree dissertation]. São Paulo: São Paulo University Nursing School; 2010.

\begin{abstract}
This is a qualitative research with comprehensive approach that has as object the educational practices of the 'multiply agents' of Project Our Children: Windows of Opportunities, an experience of intervention at the scope of basic attention/family's health that occurred in the city of São Paulo and was focused on the promotion of child development trough the strengthening of family care for pregnant women and children under six years.

Goals: (1) describe the educational practices of professionals with the health teams and families; (2) identify other training experiences that influenced these practices; and (3) correlate the reported experiences with the occurred process of project's formation.

Method: the topical life story was chosen because the object of study is limited to the subject's given area of experience, in this case, their health education practices. The stories, in number of six, were obtained through interviews combining an open and attentive listening for the exploration and deepening of the subjects' experiences with an attitude policy for attainment of general information and maintaining the focus of investigation.
\end{abstract}

Results: in the material collected were identified the empirical categories significant aspects of the training received; perceived impact on their own attitudes and behaviors; openness to listen; understanding of social determinants of health-disease; emancipatory and regulatory practices; intersectorial practices; strengthening of family cares - that in the discussion were combined with the analytical categories - learning to know, learning to do, learning to live together, learning to be; dialogical praxis; psychological and community empowerment; freedom and autonomy; regulation and social emancipation. The main results refer to aspects of the training received, the educational practices developed with the teams and families and the perception of the impact of these actions with the families.

Conclusion: Both the training received and the developed practices characterized by the expansion of the biomedical gaze because they include emotional and relational aspects of the individuals, groups and families. All subjects recognize and value the critical and participatory approach of the training they received, the impact of it on certain attitudes and behavior (empowerment of the professionals), more openness to listen and some kind of transformation in their educational practices in the sense of the empowerment of the population. As to the incorporation of attitudes and practices based on respect for autonomy of the population (regulation - emancipation dialectic), it varied from subject to subject, with a noticeable preponderance of the pole of social emancipation.

Descriptors: Primary Health Care, Health Education, Health Promotion, Child Health. 
Maricondi MA. Caracterización de las prácticas educativas de los 'agentes multiplicadores' del Proyecto Nuestros Párvulos: Ventanas de Oportunidades. [Disertación de master). Sao Paulo: Escuela de Enfermería de la Universidad de Sao Paulo; 2010.

\section{Resumen}

Esta es una pesquisa cualitativa de abordaje comprensivo que tiene como objeto la caracterización de las prácticas educativas de los 'agentes multiplicadores' del Proyecto Nuestros Párvulos: Ventanas de Oportunidades, una experiencia de intervención en el ámbito de la atención básica/salud de la familia que tuvo lugar en la ciudad de Sao Paulo y volcada para la promoción del desarrollo infantil a través del fortalecimiento de los cuidados familiares para gestantes y párvulos menores de seis años. Objetivos: (1) describir las prácticas educativas de los profesionales con los equipos de salud y las familias; (2) identificar otras experiencias de formación que influyeron esas prácticas; (3) correlacionar las experiencias relatadas con el proceso de formación acontecido en el Proyecto Ventanas. Método: fue escogida la historia de vida tópica porque el objeto de estudio está circunscrito a una determinada área de experiencia de los sujetos, en este caso, sus prácticas educativas en salud. Las historias, en número de seis, fueron obtenidas por medio de entrevistas combinando una escucha abierta y atenta para la exploración y profundización de las experiencias de los sujetos y una actitud directiva para la recolección de informaciones generales y para mantener el foco de la investigación. Resultados: en el material recolectado fueron identificadas las categorías empíricas - aspectos significativos de la formación recibida; percepción de impacto en las propias actitudes y conductas; abertura para la escucha; comprensión de las determinantes sociales del proceso salud-enfermedad; practicas de emancipación y de regulación; practicas intersectoriales; fortalecimiento de los cuidados familiares - que en la discusión fueron articuladas con las categorías analíticas - aprender a conocer, aprender a hacer, aprender a convivir y aprender a ser; praxis dialógica; 'empowerment' sicológico y comunitario; libertad y autonomía; regulación y emancipación social. Los resultados más relevantes se refieren a aspectos de la formación recibida, de las prácticas educativas desarrolladas con los equipos y las familias y la percepción de impacto de ese actuar con las familias. Conclusión: tanto la formación recibida así como las prácticas desarrolladas se caracterizan por la ampliación de la mirada biomédica porque incluyen aspectos emocionales y de relación de individuos, grupos y familias. Todos los sujetos reconocen y valorizan el abordaje critico-participativo de la formación que recibieron, el impacto de este sobre determinadas actitudes y comportamientos ('empowerment' de los profesionales), un sentido más abierto para escuchar y algún tipo de transformación en sus prácticas educativas en el sentido del 'empowerment' de la población. En lo que se refiere a la incorporación de actitudes y prácticas orientadas por el respeto a la autonomía de la población (dialéctica regulación-emancipación), esta fue variando de sujeto para sujeto con una preponderancia perceptible del polo de la emancipación social.

Descriptores: Atención Primaria de Salud, Educación en Salud, Promoción de la Salud, Salud del Niño 


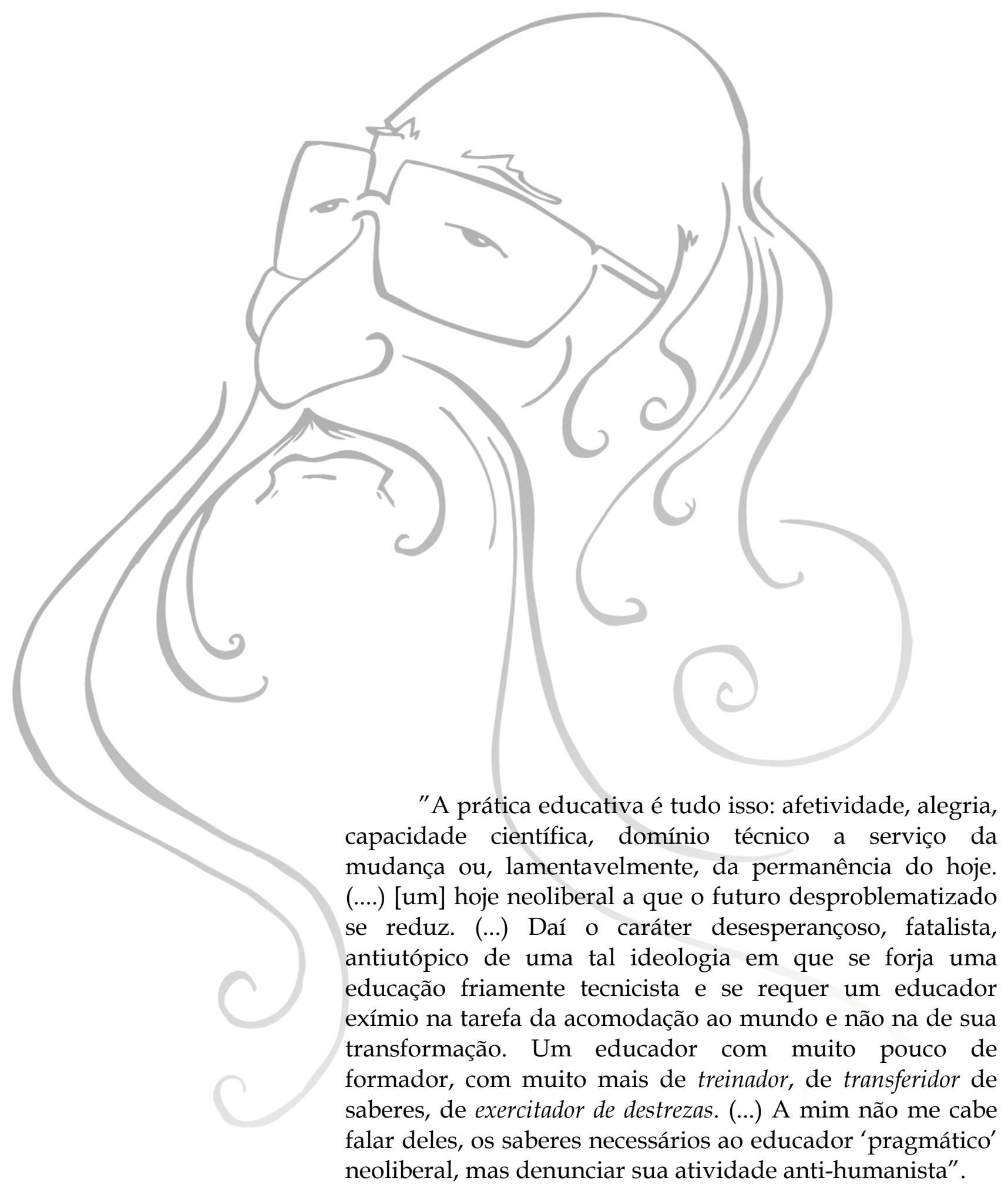

Extraído de:

Freire P. Pedagogia da autonomia: saberes necessários à prática educativa. 36 ed. Paz e Terra: São Paulo (SP); 2007. 


\section{SUMÁRIO}

\section{APRESENTAÇÃO}

\section{INTRODUÇÃO}

1.1 A relevância das práticas educativas em saúde no âmbito da atenção básica 13

1.2 Educação e promoção da saúde: uma revisão da literatura científica

1.30 nascimento do objeto de estudo a partir da experiência do

Projeto 'Nossas Crianças: Janelas de Oportunidades'

1.3.1 Breve descrição do Projeto Janelas: conceitos centrais e principais

aspectos operacionais

1.3.2 Proposições centrais do Projeto Janelas para as equipes de saúde e as famílias

\section{CONCEPÇÃO E DESENVOLVIMENTO DA PESQUISA}

2.1 0 problema de pesquisa

2.2 A finalidade

2.3 Os objetivos

2.4 Metodologia

2.4.1 A entrevista e a coleta dos dados

2.4.2 Os sujeitos da pesquisa

2.4.3 Análise de dados

\section{RESULTADOS E ANÁLISE}

3.1 Quem são os sujeitos da pesquisa

3.20 que dizem os sujeitos da pesquisa

3.2.1 'Aprender a conhecer' e 'Aprender a conviver': a formação recebida

3.2.1.1 Sobre a formação que receberam

3.2.1.2 Sobre a percepção de impacto em suas próprias atitudes e condutas

3.2.2 'Aprender a fazer': as práticas educativas desenvolvidas

3.2.2.2 Percepção de valores sociais e compreensão dos determinantes sociais do processo saúde-doença 
3.2.3 'Aprender a conviver' e 'Aprender a ser': percepção de impacto das práticas educativas desenvolvidas com as famílias e comunidades

\section{CONSIDERAÇÕES FINAIS}

\section{REFERÊNCIAS BIBLIOGRÁFICAS}

\section{LISTA DE QUADROS}

I. Categorias empíricas encontradas e sua relação com os quatro pilares do conhecimento da UNESCO

II. Aspectos metodológicos relevantes para a sistematização de processos de formação de profissionais para atuarem com ações educativas

III. Determinação social da saúde e conceitos de saúde segundo Dowbor

IV. APRENDER A FAZER: correlacionando práticas, conceitos, abordagens e paradigmas

\section{ANEXOS}

A. Parecer do Comitê de Ética em Pesquisa da Escola de Enfermagem da USP

B. Conceitos centrais do Projeto Janelas: competências familiares na atenção a crianças de zero a seis anos, família, resiliência, patrimônio e rede social da família

C. Instrumento de coleta de dados

D. Termo de consentimento livre e esclarecido

E. Mapa da implantação do Projeto Janelas

F. Entrevistas 
Apresentação

Sou de uma geração que acreditou e lutou por mudanças profundas no campo pessoal, social e político. No campo pessoal, pela liberdade de ser, sentir e se relacionar. No campo social, pela convivência solidária, com participação e sentido comunitário. No campo político, contra as desigualdades sociais, injustiças de qualquer tipo e abuso de poder pelas instituições - a família, a escola, a igreja, o governo.

Entrei no Instituto de Psicologia da USP quando a repressão dos militares começava a se instaurar de maneira ostensiva e nós inventávamos jeitos de sobreviver e resistir sem se perder ou confundir.

Poderia apresentar minha carreira profissional em dois tempos, como um jogo de futebol: $1^{\circ}$ tempo. o da formação psicanalítica, do trabalho clínico em consultório e das supervisões com alunos do último ano de Psicologia, em várias Faculdades e Universidades particulares, em São Paulo, Guarulhos, Mogi das Cruzes; 2ํtempo. o da formação prática, em serviço mesmo, com as políticas públicas, inicialmente no campo da Assistência e Desenvolvimento Social - a militância pelos direitos da criança e do adolescente trabalhando na FEBEM - e mais recentemente, de 2001 para cá, no campo da Saúde - a defesa do SUS (Sistema Único de Saúde), a experiência de implantação da Estratégia Saúde da Família e do Projeto Janelas, trabalhando inicialmente na Monte Azul e atualmente para o UNICEF (Programa Família Brasileira Fortalecida) e Ministério da Saúde (Projeto AMQ Avaliação para Melhoria da Qualidade da Estratégia Saúde da Família) 
- experiências estas que me formaram como formadora a partir de um compromisso e uma verdadeira paixão pela tarefa educativa.

O mestrado chegou para mim inaugurando um novo tempo. Uma nova fase da vida que se inicia? Esse futuro ainda sem cara que irei construindo passo a passo. 


\section{INTRODUÇÃO}

\subsection{A relevância das práticas educativas em saúde no âmbito da atenção básica}

A educação em saúde encontra um espaço privilegiado na atenção básica, pois é neste contexto que ocorre uma maior proximidade com a população através de ações de caráter preventivo e de promoção da saúde.

A educação em saúde tem sido praticada de modos muito diferentes em cada momento histórico, mas se constitui basicamente de um conjunto de saberes e práticas profissionais (raramente articuladas aos saberes e práticas populares) orientadas para o controle, a prevenção e a promoção da saúde da população.

Segundo Starfield (2002), a atenção primária deve ser vista em suas inter-relações enquanto um nível de atenção à saúde, uma estratégia de organização dos serviços e uma determinada 'filosofia' que permeia as intervenções neste âmbito, podendo resultar em uma capacidade de resposta a cerca de $85 \%$ das necessidades de saúde prevalentes em uma determinada população.

Desde 1976, com a Declaração de Alma-Ata, cidade da antiga URSS que foi sede da Conferência Internacional sobre Cuidados Primários de Saúde, a atenção primária vem ganhando destaque e capitalizando esforços de governos no sentido de se transformar em porta de entrada dos sistemas nacionais de saúde de vários países.

"Os cuidados primários de saúde [...] fazem parte integrante tanto do sistema de saúde do país, do qual constitui a função central e o foco principal, quanto do desenvolvimento social e econômico global da comunidade. Representam o primeiro nível de contato dos indivíduos, da família e da comunidade com o sistema nacional de saúde, pelo qual os cuidados de saúde são levados o mais proximamente possível aos lugares onde pessoas vivem e trabalham, e constituem o primeiro elemento de um continuado processo de assistência à saúde" (Seção VI: Declaração de Alma-Ata, 1976). 
Estando tão próximo das famílias e comunidades, o trabalho das equipes da atenção primária é fortemente comandado pelas relações entre os sujeitos. Merhy (1997) concebe o trabalho vivo em saúde como aquele que se apropria dos meios de produção - ferramentas ou tecnologias - para transformar seu objeto e, assim, construir um novo produto com a finalidade social de satisfazer as necessidades de saúde da população. Inspirado em Ricardo Bruno Mendes Gonçalves, ele propõe uma classificação das tecnologias em dura (hard), leve/dura e leve (soft). À tecnologia dura corresponderia o uso de máquinas e equipamentos, normas e estruturas organizacionais. À tecnologia leve/dura, os saberes bem organizados, estruturados, normalizados, mediados por indivíduos e adquiridos através de processos de aprendizagem como, por exemplo, a clínica e a epidemiologia. A tecnologia leve diz respeito ao encontro interativo entre trabalhadores e usuários, com uma determinada expectativa de satisfação, acolhimento, vínculo e resultado. Merhy defende a centralidade nas tecnologias leves com vistas à transformação do trabalho morto em trabalho vivo. Desde este ponto de vista, os serviços de atenção primária estruturar-se-iam a partir das tecnologias leve e leve/dura, pois são aqueles que mais demandam conhecimentos técnicos e habilidades relacionais voltadas para o cuidado, a escuta e a reflexão conjunta sobre determinantes sociais do processo saúde-doença.

Reyes, Abalo e Labrada (1999) chamam a atenção para a importância de uma forte aliança entre conhecimentos técnicos dos profissionais de saúde e vontade política dos governos.

"En Cuba existe una fuerte voluntad política para seguir mejorando la salud de la población expresada en los niveles de desarrollo actual de la atención primaria de salud, cuyo recurso humano fundamental es el médico y la enfermera de la familia. Estos profesionales necesitan nuevos conocimientos para desarrollar una educación para la salud más efectiva y creativa" (Reyes y al, 1999: 176).

A educação em saúde é uma área multifacetada e interdisciplinar que busca articular concepções de muitas disciplinas tais como a sociologia, a antropologia, a 
filosofia, a pedagogia e a psicologia. Diferentes resultantes de diferentes integrações de saberes e ideologias espelham compreensões de mundo demarcadas por distintas posições político-filosóficas acerca do homem e da sociedade. Apesar de tantas possibilidades de vir-a-ser, várias pesquisas revelam que ainda há, de fato, uma predominância daquelas práticas de educação em saúde de tipo reducionista e prescritivo. Isto requer sérios questionamentos para o alcance de ações mais integradas e participativas.

De acordo com Oliveira (2005), as mudanças no campo da saúde pública, especialmente decorrentes do movimento da promoção da saúde, acarretaram mudanças fundamentais nos princípios da educação em saúde. Na chamada 'velha' saúde pública, o único enfoque da ação educativa era o da prevenção de doenças. A 'nova' educação em saúde, portanto, deveria superar a conceituação biomédica de saúde, uma vez que a saúde deixa de ser apenas ausência de doenças para se transformar em fonte de vida.

\begin{abstract}
"A nova abordagem da saúde pública com a sua ênfase na natureza multidimensional dos problemas relacionados à saúde, juntamente com a ênfase na promoção da 'escolha informada', abre o campo da promoção da saúde das populações a diversos tipos de disciplinas e especialistas" (Oliveira DL. 2005:424).
\end{abstract}

Na prática, há uma grande diversidade de modelos de educação em saúde que a autora sugere agrupar basicamente em duas abordagens: o modelo preventivo e o modelo radical.

'O 'modelo preventivo' de educação em saúde ou educação em saúde tradicional, baseia-se nos princípios da 'velha' saúde pública. Objetiva a prevenção de doenças a partir das postulações do behaviorismo e do individualismo. Portanto, a abordagem preventiva da educação em saúde trabalha com a idéia de que os modos de vida dos indivíduos - regime alimentar pobre, falta de exercícios, tabagismo etc. são as principais causas da falta de saúde. Nesse sentido, hábitos insalubres são tidos como conseqüência de decisões individuais equivocadas. Essa ênfase no 'individual' acaba 
produzindo uma representação de 'falta de saúde' como uma falha moral da pessoa e um discurso que culpa a vítima pelo seu próprio infortúnio. O objetivo da prevenção de doenças deve ser alcançado por meio da persuasão dos indivíduos, para que esses adotem modos de vida saudáveis ou comportamentos considerados pelos profissionais do campo da biomedicina como compatíveis com a saúde. O modelo preventivo da educação em saúde tem como pressuposto a idéia de que os profissionais da saúde sabem o que se constitui em 'estilo de vida saudável' e de que a adoção desse modo de viver a vida é uma questão de escolha pessoal. O tom individualista de tal discurso é altamente problemático e tem sido alvo de críticas" (Oliveira DL. 2005:426).

Esta abordagem do modelo preventivo assimila os princípios da pedagogia tradicional ao considerar a educação um simples instrumento de transmissão de informações.

O modelo radical de educação em saúde, por outro lado, centra-se no aumento da consciência crítica na perspectiva da mudança social. Neste modelo, o processo educacional contempla uma relação democrática entre educador e educando, onde um reconhece o valor do outro no diálogo pedagógico. Oliveira (2005) explica que a educação em saúde radical, da mesma forma que a promoção da saúde, focaliza o poder enquanto condição fundamental para o êxito do empreendimento educativo (conceito de empowerment de indivíduos e comunidades).

Vários autores (Cardoso de Melo, 1981; Gastaldo, 1997; Merhy, 1997; Stotz, 2004; Gazzinelli, 2005) discutem a questão das práticas educativas nos serviços de saúde ainda serem bastante reducionistas e prescritivas, de certa forma assemelhadas àquelas primeiras práticas 'educativas' institucionalizadas com 0 nascimento da Saúde Pública no Brasil em um contexto histórico de controle de endemias rurais, epidemias e surtos de doenças infectocontagiosas em espaços urbanos transformados pelo modo capitalista de produção; tais práticas atribuem aos indivíduos a responsabilidade de não gozarem de boa saúde, culpabilizandoos, e consideram os problemas sanitários como frutos de sua 'ignorância', podendo ser portanto resolvidos pela Educação Sanitária através da imposição de 
determinadas condutas a serem seguidas para tornar as pessoas 'mais capazes' de resolverem seus problemas de saúde.

"Esse discurso normativo, que se transformava em regras para a vida, era tido, portanto, como verdadeiro e apropriado por todos, embora devesse ser prioritariamente seguido pelos amplos setores desfavorecidos. Para esse tipo de pensamento, as condições concretas de existência não tinham relações determinantes com dada situação de saúde e de educação da população" (Donato, 2000: 29).

A educação em saúde propriamente dita estabeleceu-se como área específica nos Estados Unidos durante uma conferência internacional sobre a infância na segunda década do século XX. No Brasil, instituiu-se enquanto prática no âmbito da saúde pública e, só mais tarde, como área de estudo e pesquisa. Duas modalidades de práticas merecem destaque: a primeira envolve a aprendizagem sobre doenças, como evitá-las e como recuperar a saúde; a segunda, caracterizada como promoção da saúde a partir da década de 70 , pela Organização Mundial da Saúde/OMS, leva em conta os processos de produção social dos diferentes estados de saúde. Assim, o conceito de promoção da saúde estende-se como processo educativo para toda a população no contexto de sua vida cotidiana, indo além de uma preocupação focada nas pessoas sob risco de adoecer; além disso, amplia a análise dos determinantes do processo saúde-doença, incluindo aspectos sociais em sua gênese. Uma análise crítica contínua destas práticas educativas, derivadas tanto desta como daquela modalidade, poderá nos revelar o quanto ainda persistem as marcas da ideologia sanitária.

Para Schall e Struchiner (1999), a promoção da saúde apóia-se em um conceito ampliado e positivo de saúde, pois busca integrar aspectos individuais (físicos, mentais e emocionais), sociais e ambientais (comprometimento com a igualdade social e a preservação da natureza). As autoras denominam promoção da saúde essa educação em saúde ampliada para ambientes e políticas públicas saudáveis, com reorientação dos serviços para além dos tratamentos clínicos e curativos, que se utiliza de metodologias participativas inspiradas na educação libertadora. 
Em síntese, esta sobreposição de conceitos parece significar que a educação em saúde transformou-se em veículo através do qual o ideário da promoção da saúde está sendo operacionalizado na atenção primária.

\subsection{Educação e promoção da saúde: uma revisão da literatura científica}

Uma primeira pesquisa bibliográfica foi realizada na base de dados LILACS Sistema Latino Americano e do Caribe de Informação em Ciências da Saúde utilizando-se os descritores 'Educação em Saúde' AND 'Atenção Básica', que localizou 181 publicações; refinando para o período de 1998 a 2008, este montante foi reduzido a 55 títulos. Destes, 43 são artigos de revistas científicas, tendo sido possível acessar 26 deles: um do Chile, 13 de Cuba e 12 do Brasil. Importante chamar a atenção para o fato dos textos cubanos estarem $100 \%$ disponíveis diretamente na base consultada, o que não ocorre com os textos brasileiros, mesmo fazendo pesquisa direta nas revistas (o acesso foi de $12 \mathrm{em} \mathrm{17).} \mathrm{Quanto}$ aos demais países, três em quatro artigos chilenos, um da Venezuela, um do Equador e todos os sete artigos argentinos não estão disponíveis. Os demais títulos referem-se a três dissertações de mestrado (Brasil), três manuais (Brasil), três livros (Brasil) e três documentos governamentais (Uruguai, Bolívia e Nicarágua).

Os artigos cubanos tratam de: a) pesquisas sobre o nível de conhecimento dos pacientes diabéticos e hipertensos sobre sua doença; b) a capacidade de reconhecimento, pelo médico de família, dos sintomas de um quadro de abdômen agudo cirúrgico e seu nível de conhecimento sobre a técnica de reanimação cardiopulmonar; c) análise de documentos orientadores da formação do 'Médico de Família e do Médico Especialista em Medicina Geral Integral' e dos discursos de Fidel Castro com vistas à caracterização do perfil teórico-técnico e políticoideológico desse profissional; d) estudos sobre a necessidade de educação, prevenção e controle de doenças como a candidíase e a pitiríase versicolor; e) avaliação do papel da enfermeira e/ou do médico de família na educação contra o tabagismo, o uso indevido de drogas, controle do paciente diabético e busca ativa de pacientes hipertensos. 
Os artigos brasileiros abordam os seguintes temas: treinamento do médico clínico geral em diagnóstico e tratamento da depressão; nível de conhecimento de gestantes sobre exames de deteç̧ão precoce de câncer cérvico-uterino e de mama, e de pacientes diabéticos sobre cuidados com os pés; atividades de enfermeiros do PSF no campo da comunicação/informação em saúde com grupos de gestantes; prevenção de gravidez na adolescência; informação e apoio psicosocial ao paciente chagásico; integralidade da atenção com vistas à redução da mortalidade infantil e materna; qualificação de profissionais da atenção básica através de EAD (ensino à distância); articulação conceitual entre Educação, Comunicação e Saúde.

O artigo chileno apresenta uma pesquisa que buscou determinar o grau de conhecimento de um grupo de mulheres entre 40 e 64 anos, usuárias do serviço de atenção primária, sobre a fase do climatério. Os resultados apontaram que não há relação estatisticamente significante entre o grau de conhecimento e a idade das mulheres, nem tampouco com a fonte de aquisição desse conhecimento; que a relação estatisticamente significante ocorreu em relação ao seu nível educacional.

Da leitura do conjunto dos 26 artigos é possível derivar as seguintes considerações:

1. Que a despeito da diferença de regime político-econômico entre Cuba e Brasil, as ações educativas no campo da saúde são predominantemente de tipo informativo e de caráter prescritivo com vistas à assunção de estilos de vida saudáveis pelos grupos considerados de risco, sejam eles diabéticos, hipertensos, adolescentes grávidas, etc.;

2. Que dentre os profissionais de saúde do nível primário de atenção, os enfermeiros são aqueles que mais experiência prática e de pesquisa demonstram ter sobre $o$ assunto em pauta;

3. Que os enfermeiros fazem grupos educativos com os recortes programáticos vigentes na prática da saúde pública tradicional; que utilizam preponderantemente metodologias de transmissão de informações sobre doenças e seu tratamento (dimensão assistencial), com muito pouco de empoderamento para o exercício da cidadania (dimensão emancipatória). 
4. Que atividades de comunicação/informação em saúde começam a ser implementadas de forma inovadora e participativa, mas ainda com baixa freqüência e perspectiva de continuidade.

É interessante destacar também que dois artigos brasileiros ${ }^{1},{ }^{2}$ e um artigo cubano ${ }^{3}$ diferenciam-se do conjunto estudado porque os primeiros alinham-se ao paradigma da Saúde Coletiva através de conceitos centrais como determinação social do processo saúde-doença, integralidade do cuidado, participação popular e educação emancipatória; o segundo enfatiza a importância da atenção primária no sistema de saúde cubano e apresenta o campo da Educação em Saúde em termos conceituais e metodológicos.

Em síntese, desta revisão inicial é possível concluir que, apesar das mudanças de concepção que vêm ocorrendo ao longo do tempo, particularmente no Brasil enquanto fruto de mobilização social e conquista do Movimento da Reforma Sanitária, a educação em saúde na atenção primária ainda mantém seu caráter prescritivo e normativo em defesa de um comportamento saudável de caráter individual, sem problematizar as raízes do processo saúde-doença, o que contribuiria para a transformação da realidade de diferentes grupos e classes sociais.

Uma segunda busca bibliográfica foi realizada na base de dados LILACS com os descritores 'Promoção da Saúde' AND 'Saúde da Criança', porque o Projeto Janelas objetiva, em última análise, a promoção da saúde da criança. Foram encontradas 50 publicações: cinco dissertações e teses, 17 documentos governamentais e de agências internacionais e 28 artigos de revistas. Os temas

\footnotetext{
${ }^{1}$ Donato AF, Rosenburg CP. Algumas idéias sobre a relação Educação e Comunicação no âmbito da Saúde. Saúde e Sociedade, São Paulo, 12 (2):18-25, jul-dez 2003.

2 Vasconcelos EM. Educação popular como instrumento de reorientação das estratégias de controle das doenças infecciosas e parasitárias. Cadernos de Saúde Pública, Rio de Janeiro, 14(Sup. 2):39-57, 1998.

3 Reyes WG. Abalo JG. y Labrada MCP. ¿Cómo hacer más efectiva la educación en salud en atención primaria? Rev Cubana Med Gen Integr, Cuba, 15(2):176-83, 1999.
} 
referem-se a: acompanhamento antropométrico, capacidades físicas e motoras, desenvolvimento anatômico, fisiológico e psicológico, morbidade pediátrica, saúde do pré-escolar, aleitamento materno, nutrição infantil, AIDPI/Atenção Integrada às Doenças Prevalentes na Infância, teatro educativo e IRA (infecções respiratórias agudas) e avaliação de campanhas de prevenção de acidentes com fogos de artifício. Os países são: Chile (14); México (um); Guatemala (um); Brasil e Brasil / OPAS (23); USA / OPAS (nove); Peru / UNICEF (um); Guatemala (um). Dos pouquíssimos artigos acessíveis, apenas $u^{4}$ foi considerado relevante para 0 presente estudo.

A terceira pesquisa foi feita na perspectiva de ampliar o leque de possibilidades da segunda pesquisa, por isso incluiu o descritor 'Educação em Saúde'. Assim, com os descritores 'Educação em Saúde' OR 'Promoção da Saúde' AND 'Saúde da Criança', encontramos 67 publicações, dentre artigos de revistas, documentos governamentais, acadêmicos e de agências internacionais que, basicamente, abordam os mesmos temas anteriores, dando grande ênfase aos módulos e manuais de capacitação no campo da promoção da saúde da criança de até cinco anos, especialmente em AIDPI/Atenção Integrada às Doenças Prevalentes na Infância. As agências internacionais da ONU (OPAS e UNICEF) intensificaram seu apoio aos governos latino-americanos para a elaboração e implementação de planos de ação para o desenvolvimento integral de crianças, prevenção de maus tratos e instalação de centros de educação infantil. Os países são: Chile (sete); Peru (três); México (dois); Panamá (dois); Equador (dois); Argentina (um); Guatemala (um); Bolívia (um); Brasil e Brasil / OPAS (32); UNICEF (três). Apesar de uma maior quantidade de publicações, nenhum texto foi considerado de interesse para este estudo.

A quarta pesquisa bibliográfica contemplou a categoria empowerment por ser ela uma categoria analítica que integra o nosso marco teórico de referência. Utilizandose o descritor 'Promoção da Saúde' AND a palavra 'Empowerment', foram identificadas 24 publicações. Os assuntos tratados em sete dissertações e teses,

${ }^{4}$ Buss PM. Promoção da saúde na infância e adolescência. Revista Brasileira de Saúde Maternoinfantil, Recife, 1(3): 279-82 set.-dez. 2001. 
um livro, um documento de agência internacional e 15 artigos de revistas referemse a: promoção da saúde através do combate à pobreza e desenvolvimento local, ações educativas em pediculose, nefrologia, fonoaudiologia e saúde bucal, ações de promoção nas escolas, comunidades e Programa Saúde da Família, ações com grupos de mulheres e grupos de adolescentes. São 20 publicações do Brasil, três da Colômbia e uma de USA / OPAS. Dentre os textos disponíveis deste grupo, foram selecionados quatro artigos de revistas científicas. ${ }^{5,}, 7,8$.

Em síntese, é possível afirmar que o tema saúde da criança é tratado de maneira muito restrita na literatura científica, apenas em seus aspectos de desenvolvimento físico e motor, imunização e aleitamento/nutrição. São demonstrados investimentos importantes de governos latino-americanos e agências da ONU (OPAS/OMS; UNICEF) na capacitação em AIDPI/Atenção Integrada às Doenças Prevalentes na Infância. Outras publicações tratam de advocacy da infância e chamam a atenção para a necessidade de programas de educação infantil e fortalecimento da ação comunitária com vistas ao acesso a serviços básicos, especialmente água potável e saneamento. Alguns poucos artigos tratam de ações educativas com grupos de mulheres, adolescentes e grupos comunitários (empowerment psicológico e comunitário), em creches e escolas (por exemplo, para prevenção da pediculose e saúde bucal), utilização de campanhas de prevenção de acidentes com fogos de artifício e do teatro educativo no diagnóstico e tratamento de infecções respiratórias agudas.

Nenhuma das quatro pesquisas localizou publicações sobre promoção do desenvolvimento infantil através do fortalecimento dos cuidados familiares.

\footnotetext{
${ }^{5}$ Stotz EM. Promoção da saúde e cultura política: a reconstrução do consenso. Saúde e Sociedade, São Paulo, 13(2): 5-19, maio-ago, 2004.

${ }^{6}$ Carvalho SR. Os múltiplos sentidos da categoria 'empowerment' no projeto de Promoção à Saúde. Cadernos de Saúde Pública, Rio de Janeiro, 20(4):1088-1095, jul-ago, 2004.

${ }^{7}$ Carvalho SR. As contradições da promoção à saúde em relação à produção de sujeitos e a mudança social. Ciência \& Saúde Coletiva, Rio de Janeiro, 9(3):669-678, 2004b.

${ }^{8}$ Lefevre F, Lefevre AMC. Saúde, empoderamento e triangulação. Saúde e Sociedade, São Paulo, 13(2): 32-38, maio-ago, 2004.
} 
Portanto, podemos concluir que, sendo praticamente inexistentes os estudos sobre fortalecimento dos cuidados familiares na atenção a gestantes e crianças de zero a seis anos pelas equipes de saúde no âmbito da Atenção Básica/Estratégia Saúde da Família, são igualmente inexistentes as suas práticas nos serviços. Esta conclusão, acrescida do fato de o Projeto 'Nossas Crianças: Janelas de Oportunidades' ser uma proposta de intervenção no campo da promoção da saúde da criança que foi extensamente implantada na cidade de São Paulo, justifica plenamente o interesse do presente estudo.

\subsection{O nascimento do objeto de estudo a partir da experiência do Projeto 'Nossas Crianças: Janelas de Oportunidades'}

Nosso interesse de pesquisa nasceu da experiência de formação dos 'agentes multiplicadores'9 do Projeto 'Nossas Crianças: Janelas de Oportunidades' e do acompanhamento de sua atuação com vistas à implantação do projeto na cidade de São Paulo, para o que foram constituídas redes regionais de multiplicadores que funcionaram regularmente durante um determinado período de tempo. Esses profissionais, em grande parte enfermeiros, eram membros das equipes de Saúde da Família ou coordenavam a estratégia no nível regional, distrital ou local do município de São Paulo.

\footnotetext{
9 O termo 'agente multiplicador' tem sido muito utilizado e muito pouco discutido. Integra a linguagem corrente daqueles que atuam no campo da implantação e implementação de políticas, programas e projetos, de onde parece ter vindo sem passar, entretanto, pelo crivo da problematização e receber tratamento teórico capaz de elevá-lo à condição de conceito. No contexto das abordagens pedagógicas centradas na transmissão de informações, no treinamento de habilidades e na replicação de experiências-experimentos, o uso deste termo é adequado e compatível com o referencial teórico adotado, referencial este que Paulo Freire (2005) denomina concepção 'bancária' da educação. Mas, o que dizer de sua utilização no contexto de práticas educativas que utilizam metodologias participativas e problematizadoras inspiradas nas vertentes críticas da pedagogia, como é o caso do Projeto Janelas? Equívoco? Incoerência? Contradição? Como alternativa, em lugar de 'multiplicadores', a Profa. Dra. Ausonia Favorido Donato sugere a utilização do termo 'socializadores', uma vez que socialização envolve (a) implicação ideológica, (b) relação com o outro e (c) compromisso com a mudança, sendo possível, portanto, referenciá-la à concepção problematizadora e libertadora da educação de Paulo Freire (2005). Não tendo sido possível desenvolver, aprofundar nem resolver o paradoxo apenas delineado nesta nota de rodapé, além do fato de todos os textos produzidos sobre o Projeto Janelas terem utilizado o termo ora colocado 'sob suspeita', ressalvamos que, no contexto deste trabalho e a título provisório, colocá-lo-emos sempre entre aspas.
} 
O Projeto Janelas visava à promoção da saúde da criança através do fortalecimento dos cuidados familiares e previa ações de capacitação de profissionais responsáveis pela formação de outros profissionais, chamados de 'agentes multiplicadores' pela equipe coordenadora do projeto, na perspectiva de uma ampliação das possibilidades de vínculo e escuta das famílias pelas equipes de PSF, em diferentes espaços de intervenção além daqueles convencionais das consultas e grupos de orientação, utilizando-se materiais educativos especialmente elaborados para tal finalidade, quais sejam: a cartilha da família, o manual de apoio da equipe e a ficha de acompanhamento dos cuidados da criança em consultas médicas e de enfermagem. Em tese, este projeto parece incorporar essa nova perspectiva da educação em saúde, dado que enfatiza o caráter emancipatório das práticas propostas tanto para os profissionais de saúde como para as famílias.

\subsubsection{Breve descrição do Projeto Janelas: conceitos centrais e principais aspectos operacionais}

Fruto de cooperação técnica firmada entre a Secretaria Municipal da Saúde de São Paulo, o UNICEF e a Associação Comunitária Monte Azul, o Projeto Janelas foi desenvolvido entre 2001 e 2004. Outras instituições de experiência renomada na área do desenvolvimento infantil, particularmente primeira infância, foram convidadas a compor um grupo técnico que ficou responsável por planejar e executar todas as ações necessárias à concretização de seu objetivo, qual seja, o de promover o desenvolvimento de crianças de zero a seis anos do município de São Paulo através da qualificação dos cuidados familiares, tendo as Unidades e Equipes de Saúde da Família como seus sujeitos diretamente responsáveis.

Com base no princípio da equidade foram selecionados para a primeira fase da implantação os distritos sanitários de maior índice de exclusão social, segundo os critérios de maior contingente de crianças menores de cinco anos, maior incidência de partos prematuros, maior incidência de gravidez na adolescência e maior concentração de famílias de baixa renda, ficando a área de abrangência constituída pelos distritos do Jardim São Luis, Jardim Ângela, Grajaú, Cidade Ademar, Parelheiros, Vila Brasilândia, Sé, Cidade Tiradentes, Itaquera e São 
Miguel. Assim, famílias de crianças de zero a seis anos e gestantes destas áreas são as destinatárias das ações do projeto.

O grupo técnico responsável ficou constituído pela Secretaria Municipal da Saúde/Programa Saúde da Família, Secretaria Municipal da Saúde/COGest - Área Temática Saúde da Pessoa com Deficiência, Associação Comunitária Monte Azul, UNICEF/Fundo das Nações Unidas para a Infância, CREN/Centro de Recuperação e Educação Nutricional (vinculado à UNIFESP), Escola de Enfermagem da USP (NACE:AENSC), Pastoral da Criança (Diocese de Santana) e JICA/Japan International Cooperation Agency.

As ações desenvolvidas podem ser organizadas em cinco blocos:

1: elaboração da cartilha da família 'Toda hora é hora de cuidar', do manual de apoio da equipe e da ficha de acompanhamento dos cuidados para promoção da saúde da criança para utilização pelo médico e enfermeiro. Tiragem: 45.000 exemplares da cartilha, 5.000 exemplares do manual e 100.000 fichas de acompanhamento.

2: capacitação de 114 'agentes multiplicadores' em quatro oficinas com carga horária de 40 horas (duas na região Sul, uma na região Norte e uma na região Leste).

3: capacitação de 304 Equipes de Saúde da Família ou PACS/Programa de Agentes Comunitários de Saúde, de 57 Unidades Básicas de Saúde, levada a cabo por 98 'agentes multiplicadores'

4: acompanhamento e avaliação de processos. Estudo de linha de base das competências familiares utilizando-se metodologia quantitativa desenvolvida pelo UNICEF. Entrevistadas 323 famílias de crianças de zero a seis anos em 2004, residentes nos bairros do Jardim Alfredo, Vila Aparecida, Jardim Varginha, Vila Ramos e Jardim Guarani. Constituição das Redes Regionais de Multiplicadores do Projeto Janelas (Sul, Leste e Centro-Oeste) cujas reuniões ocorreram bimensalmente durante o mesmo ano.

5. pesquisa avaliativa intitulada 'Avaliação da implantação de novos instrumentos para o fortalecimento das ações de promoção do desenvolvimento infantil na área de atuação do Programa Saúde da Família do Município de São Paulo', 
coordenada pela Escola de Enfermagem da USP e financiada pelo CNPq, durante os anos de 2005 e 2006. O relatório final foi encaminhado ao órgão financiador em fevereiro de 2007.

Esta pesquisa avaliativa compôs-se de seis estudos:

1. Avaliação da efetividade da Cartilha 'Toda hora é hora de cuidar' através da percepção dos cuidadores;

2. Avaliação da efetividade da Cartilha 'Toda hora é hora de cuidar' através da percepção dos agentes comunitários de saúde;

3. Avaliação da Ficha de Acompanhamento dos cuidados para a promoção da saúde da criança;

4. Avaliação da Capacitação dos Multiplicadores através de análise documental;

5. Avaliação da Capacitação dos Multiplicadores através da percepção dos sujeitos participantes do processo;

6. Caracterização dos Cuidados Familiares oferecidos às crianças antes da implantação do Projeto Janelas.

(Chiesa, 2005).

A presente pesquisa não é um estudo avaliativo: seu recorte é a caracterização das práticas educativas desenvolvidas por esses 'agentes multiplicadores' durante um determinado lapso de tempo que vai desde a sua participação nas 'Oficinas de Capacitação de Multiplicadores do Projeto Janelas' (segundo semestre de 2003) e nas reuniões das 'Redes Regionais de Multiplicadores' (ano de 2004) até o ano de 2009.

As dissertações de mestrado de Correia (2007) e de Oliveira (2007) são de especial interesse porque representam o nosso ponto de partida e ancoragem na busca de novos conhecimentos sobre as práticas educativas desses sujeitos.

$\mathrm{Na}$ dissertação de mestrado intitulada 'Avaliação da capacitação dos multiplicadores do projeto "Nossas Crianças: Janelas de Oportunidades", a partir da percepção dos sujeitos participantes do processo', Correia (2007) buscou relacionar o referencial teórico do projeto, expresso na metodologia utilizada nas 
oficinas de capacitação, com um possível ganho de 'empowerment' por parte dos profissionais participantes. Pesquisou o grau de apreensão dos conteúdos programáticos pelos participantes e a adequação da estratégia pedagógica escolhida à finalidade de 'multiplicação' junto às equipes de saúde da família. Sendo uma pesquisa de natureza qualitativa na modalidade estudo de caso, foram utilizadas entrevistas semi-estruturadas com cada um dos oito participantes da pesquisa, e realizada análise temática. A seleção da amostra foi intencional, com critério de inclusão pautado no maior grau possível de manutenção das atividades propostas pelo projeto em suas unidades de origem, envolvendo sete mulheres e um homem, na faixa etária entre 25 e 50 anos, sendo cinco enfermeiras, uma técnica de enfermagem, uma assistente social e um médico. Foram utilizados os marcos teórico-conceituais da Promoção da Saúde (os cinco eixos da Carta de Ottawa) e da Pedagogia Crítica para analisar o material das entrevistas, seguindo o método proposto por Bardin. A autora chegou às seguintes conclusões: a) que eles demonstram uma avaliação fortemente positiva das vivências de grupo que tiveram durante a oficina, além da forma de apresentação dos conteúdos sobre integralidade do cuidado, desenvolvimento durante os primeiros seis anos de vida, resiliência, competências familiares, família e rede social, percebendo-se instrumentalizados para o trabalho de promoção da saúde da criança; e b) houve adequação na escolha da metodologia problematizadora, a qual oportunizou o resgate da reflexão sobre as realidades cotidianas, a experiência de trabalho em equipe e a participação criativa nas diferentes atividades desenvolvidas durante a oficina e no serviço.

A dissertação de mestrado de Oliveira (2007), intitulada 'Análise documental do processo de capacitação dos multiplicadores do projeto "Nossas Crianças: Janelas de Oportunidades" no município de São Paulo à luz da promoção da saúde', analisou os conteúdos programáticos, as estratégias pedagógicas e as técnicas de avaliação do processo ensino-aprendizagem desenvolvidos nas oficinas de capacitação do Projeto Janelas com vistas à identificação das principais tendências pedagógicas ali contidas, além de conteúdos e conceitos relacionados ao empoderamento dos sujeitos. Também reconheceu no paradigma da Promoção da Saúde uma potencialidade de reorganização dos serviços de saúde e de 
estruturação de um cuidar baseado na visão materialista histórica e dialética do processo saúde-doença resultante dos modos de viver e de trabalhar em um determinado momento histórico e social. Apesar da referida potencialidade, ressalvou que tal mudança só será possível na medida em que o setor saúde assumir o desafio de formar seus profissionais utilizando-se de métodos educativos geradores de reflexão crítica com vistas à superação do modelo biomédico, especialmente nas práticas dos profissionais da Atenção Básica. Considerou que o Projeto 'Nossas Crianças: Janelas de Oportunidades' extrapolou a atenção ao corpo biológico incluindo a dimensão afetiva e social do cuidado da criança através da estratégia de fortalecimento das famílias. A análise documental dos diferentes registros foi feita à luz de dois marcos teórico-conceituais: no campo da Educação, a pedagogia 'freireana'; e no campo da Promoção da Saúde, as 'dimensões de saúde e bem estar' de Ronald Labonte. Indicou que a capacitação dos multiplicadores pautou-se na vertente crítica da Pedagogia representada pelas seguintes categorias 'freireanas': a) autonomia e liberdade dos sujeitos, b) bem querer aos educandos, c) complementaridade objetiva e subjetiva, d) compromisso com a mudança, e) educação permanente dos seres humanos, f) horizontalidade das relações de poder, g) práxis dialógica e h) reflexão crítica da realidade. E concluiu que 'os processos educativos embasados em pedagogias críticas favorecem a incorporação de um novo referencial para o cuidado infantil à luz do conceito positivo de saúde e a criação de um espaço acolhedor capaz de emancipar sujeitos para transformar os perfis de saúde-doença da população'. ( $p$. 11)

A experiência prática da pesquisadora na implantação do projeto aliada à reflexão crítica sobre os achados científicos destes dois trabalhos de mestrado suscitaram a seguinte questão norteadora: os profissionais formados como 'multiplicadores' do Projeto Janelas incorporaram tais bagagens em suas práticas educativas? Como? Que outras experiências de formação e de práticas teriam sido significativas para eles e por quê? 


\subsubsection{Proposições centrais do Projeto Janelas para as equipes de saúde e as famílias}

Algumas proposições estruturadoras dos processos de formação e das práticas preconizadas pelo Projeto Janelas poderiam ser sintetizadas da seguinte forma:

Primeira: as práticas educativas propostas pelo Projeto Janelas contrapõem-se à impessoalidade nas relações dos profissionais de saúde com os usuários; à naturalização dos processos sociais e conseqüente sobrevalorização do conhecimento especializado acerca do corpo físico e biológico; e às práticas corporativas prescritivas que são ineficazes frente às necessidades de saúde da população.

Segunda: as práticas educativas do Projeto Janelas buscam recuperar o foco da atenção nas necessidades de saúde da criança, desde antes de nascer até os seis anos de vida, partindo do conceito positivo de saúde e considerando a família como sua mais importante referência de proteção e cuidado.

Terceira: pela natureza socialmente complexa e determinada do processo saúdedoença, as práticas educativas do Projeto Janelas pressupõem 0 trabalho integrado e intersetorial, para frutificarem em parcerias diversas. Experiências multidisciplinares e intersetoriais possibilitam a integração dos diferentes saberes e práticas na perspectiva de uma construção coletiva do novo e da mudança.

Quarta: as práticas das equipes de saúde e dos cuidadores familiares fortalecemse através do trabalho com os materiais educativos do projeto, que abordam o tema proteger e cuidar desde uma perspectiva ampliada de família e desenvolvimento infantil, o conceito de patrimônio e rede social da família, a essencialidade dos cuidados familiares na atenção à criança de zero a seis anos e os direitos e participação da criança.

O estudo das competências familiares na atenção a crianças de zero a seis anos do UNICEF, que resultou na elaboração de uma lista de 28 competências divididas em três áreas ou domínios (Anexo B), foi subsídio técnico importante para a 
elaboração da cartilha da família e do manual de apoio 'Toda hora é hora de cuidar' pelo grupo técnico do Projeto Janelas (São Paulo, 2003).

Segundo Chiesa (2007), essas competências ou cuidados podem ser divididos em cinco blocos:

A - Proteção do corpo biológico: imunizações, higiene corporal, alimentação, prevenção de acidentes, proteção contra álcool, tabagismo e outras drogas;

B - Participação da vida comunitária: fortalecimento das redes sociais das famílias; acesso a serviços de saúde, creches, atividades culturais e de lazer;

C - Valorização das interações humanas: qualidade dos relacionamentos interpessoais, amorosidade, estimulação adequada em cada etapa do desenvolvimento infantil (as 'janelas de oportunidades'), divisão dos papéis, responsabilidades e tarefas familiares no cuidado da criança;

D - Estímulo à resiliência: defesa de direitos da criança, incluindo sua participação nas tomadas de decisão acerca do que the diz respeito, direito de inclusão da criança com deficiência;

E - Construção da autonomia: aprendizagem e auto-cuidado, convivência familiar e comunitária, socialização e auto-realização.

No Anexo B apresenta-se uma síntese dos conceitos centrais do projeto competências familiares, família, resiliência, patrimônio e rede social da família.

Quinta: essas práticas, ao mesmo tempo de formação e de cuidado, ocupam os mais diferentes espaços de encontro entre pessoas: as consultas médicas e de enfermagem, os grupos de gestantes e de puericultura, as visitas domiciliares, as reuniões comunitárias em igrejas, escolas ou creches, outros espaços intersetoriais com educadores infantis, conselheiros tutelares, professores, etc.

De todo o exposto até aqui é possível concluir que, uma vez que os saberes e práticas de fortalecimento dos cuidados familiares para a promoção da saúde da criança são quase inexistentes na literatura científica brasileira e latino-americana, a abordagem de promoção do desenvolvimento infantil na perspectiva do fortalecimento das famílias é inovadora, configurando-se em temática emergente e 
pertinente para a pesquisa no âmbito da saúde coletiva, especialmente diante da necessidade de reorganização das práticas na atenção básica.

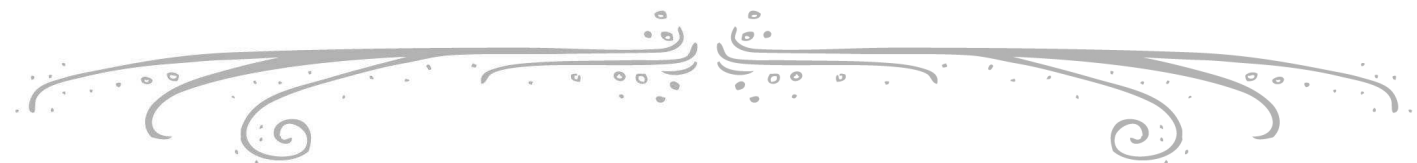




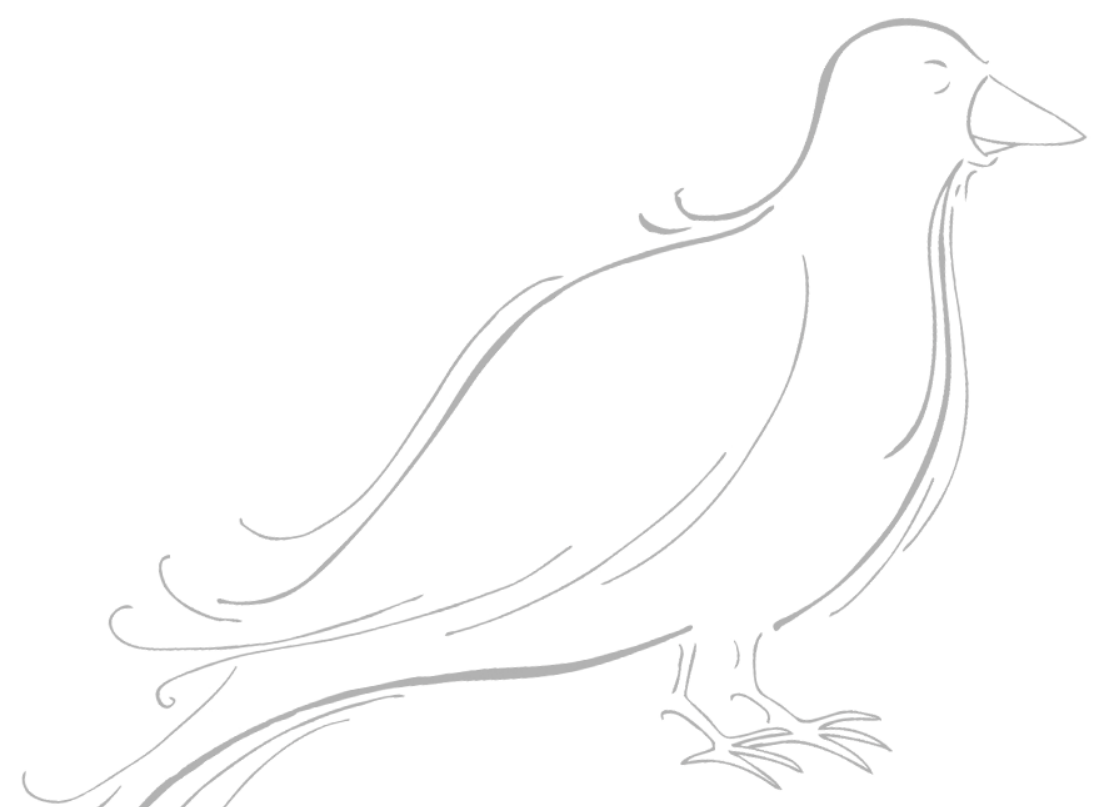

A ciência pode classificar e nomear os órgãos de um sabiá mas não pode medir seus encantos.

A ciência não pode calcular quantos cavalos de força existem nos encantos de um sabiá.

Quem acumula muita informação perde o condão de adivinhar: divinare

Os sabiás divinam

Manoel de Barros 


\section{CONCEPÇÃo E DESENVOLVIMENTO DA PESQUISA}

Este capítulo apresenta o problema de pesquisa, a finalidade, seus objetivos, e a metodologia utilizada. Explica também a escolha metodológica da história de vida tópica para caracterização das práticas educativas dos sujeitos de pesquisa.

\subsection{0 problema de pesquisa}

As práticas de educação em saúde caracterizam-se mais como instrumento de controle e culpabilização da população do que de sua emancipação, como o demonstram os resultados da revisão da literatura científica apresentados neste trabalho, que também revelaram a inexistência de estudos sobre fortalecimento dos cuidados familiares na atenção a gestantes e crianças de zero a seis anos. Como o Projeto 'Nossas Crianças: Janelas de Oportunidades' é uma proposta de intervenção neste campo, tendo sido extensamente implantado na cidade de São Paulo, com uma determinada metodologia e materiais educativos específicos, o caráter das práticas educativas dos sujeitos assim formados delimita o nosso problema de pesquisa.

O tema de estudo: as práticas de educação e promoção da saúde infantil na atenção básica.

O subtema de estudo: o recorte das práticas educativas dos 'agentes multiplicadores' do Projeto Janelas desde a sua participação nas oficinas de capacitação e nas reuniões da Rede de Multiplicadores.

O pressuposto: as práticas educativas dos sujeitos de pesquisa apóiam-se em um conceito positivo de saúde e orientam-se no sentido da formação de vínculos que levam em conta aspectos psicológicos, relacionais e sociais das famílias, gestantes e crianças atendidas, sendo a dialética dessa construção marcada predominantemente pelo pólo da emancipação e da autonomia.

\subsection{A finalidade}

- Contribuir para a reflexão sobre o caráter das práticas de educação e promoção da saúde no âmbito da atenção básica, nos espaços acadêmicos e dos serviços; 
- Contribuir para evidenciar os elementos práxicos de uma 'educação em saúde como prática da liberdade', na mais genuína acepção freireana.

\subsection{Os objetivos}

\section{Geral}

Caracterizar as práticas educativas dos 'agentes multiplicadores' do Projeto Janelas, historiando suas trajetórias e transformações de 2004 a 2009.

\section{Específicos}

1. Descrever as práticas educativas dos 'agentes multiplicadores' do Projeto Janelas, desenvolvidas com as equipes de saúde e as famílias;

2. Identificar outras experiências de formação - posteriores àquela recebida através do Projeto Janelas - que influenciaram essas mesmas práticas, como e por que.

3. Correlacionar as experiências relatadas pelos sujeitos com o processo de formação obtido no Projeto Janelas.

\subsection{Metodologia}

A metodologia de investigação foi escolhida em função de dois critérios principais:

1. Possibilitar uma escuta aberta e criativa, deixando ambos os sujeitos entrevistador e entrevistado - à vontade para comentarem, irem e voltarem nos temas e tempos de suas narrativas;

2. Equacionar a questão do tempo cronológico decorrido entre o momento do desenvolvimento das ações de implantação do Projeto Janelas e o momento da presente pesquisa, podendo a memória ser acionada sem prejuízo da legitimidade/validade dos dados assim obtidos.

Trata-se, portanto, de uma pesquisa qualitativa de abordagem compreensiva que utilizou a história de vida através de entrevistas como técnica de coleta dos dados. A história de vida e suas variantes, como a narrativa de vida, história oral e etnobiografia, são consideradas poderosas formas de descobrir e explorar como as pessoas compreendem o seu passado e articulam suas experiências individuais ao seu contexto social, interpretando-os a partir do seu presente. São técnicas que possibilitam a pesquisa acerca do sentido da experiência humana no tempo e no 
espaço. Resgatam a capacidade subjetiva do informante e a importância da dimensão singular na compreensão dos processos mais gerais. Para Breilh (1995), desde que seja possível situar e explicar seus achados à luz do marco histórico do grupo e da sociedade, as histórias de vida podem fornecer ricas informações sobre comportamentos, raciocínios, práticas e estratégias que não seriam accessíveis através de técnicas mais rígidas e de registro formal padronizado.

_"En esa dirección las categorías de la dialéctica son una herramienta indispensable para interpretar ese doble movimiento de lo general y particular hacia lo singular y de esto último hacia las instancias más amplias. En realidad lo que se puede observar por estas técnicas son los patrones de individualización de las prácticas y concepciones" (Breilh, 1995: 131).

Minayo (2007) assinala que, embora de um lado cresçam as dúvidas epistemológicas sobre o significado das narrativas de lembranças obtidas através das técnicas de história de vida, muitos esforços estão sendo empreendidos por muitos pesquisadores qualitativos no sentido de aperfeiçoá-las. As dúvidas mais comuns referem-se às seguintes perguntas:

$\checkmark$ O que acontece com a experiência quando ela vai se tornando memória?

$\checkmark$ O que acontece com as experiências quando elas vão se tornando história?

$\checkmark$ O que ocorre com a memória coletiva quando a vivência de fatos muito fortes se distancia cada vez mais no tempo?

Segundo Boaventura de Sousa Santos (2005), nossas trajetórias de vida tanto pessoais como coletivas, bem como os valores, crenças e preconceitos que elas comportam, são provas vivas de nosso conhecimento, sem o qual nossas investigações não teriam sentido. Entretanto, este saber de nossas trajetórias e valores, do qual podemos ter consciência ou não, influenciam os pressupostos não ditos de nosso discurso científico. Por isso, em lugar de negar essa via de acesso ao conhecimento, ele propõe desvelar esses pressupostos e suas influências para alcançar 'um conhecimento compreensivo e íntimo que não nos separe e antes nos una pessoalmente ao que estudamos' (Santos, 2005; 84). 
As técnicas de história de vida, através de entrevista aberta ou semi-aberta e observação participante, exigem uma consciência reflexiva maior, tanto da parte dos pesquisadores quanto dos seus interlocutores, que irão construir, conjuntamente, uma espécie de pré-texto para, depois, inseri-lo em um contexto mais complexo e amplo.

O pesquisador realiza um esforço contínuo de articulação das informações obtidas com um determinado contexto histórico, relacional e social, pois as narrativas dos sujeitos sempre têm um caráter incompleto. Os interlocutores não contam a sua vida, eles refletem sobre ela enquanto a narram, (re) construindo sentidos que vão do presente ao passado e ao futuro.

"Portanto, o investigador nunca encontrará a verdade e, sim, a versão situada dos participantes nos episódios narrativos. Igualmente, sua biografia, nalgum momento, deverá ser posta no contexto etnográfico" (Minayo, 2007: 161).

Estando o nosso interesse de pesquisa circunscrito a um determinado campo da experiência profissional dos sujeitos, a escolha da história de vida tópica fica esclarecida e justificada. E, seguindo as orientações de Minayo (2006), essas histórias não foram tiradas utilizando-se a entrevista aberta, mas combinando-se uma atitude diretiva para obtenção de informações gerais e manutenção do foco da atenção na experiência objeto da investigação com uma escuta aberta e atenta para o aprofundamento dos temas que se pretendia desenvolver e aprofundar.

\subsubsection{A entrevista e a coleta dos dados}

Buscando a criação de um ambiente relacional propício à rememoração o mais livre possível das experiências que viriam a ser relatadas naquele encontro entre pesquisador e sujeito de pesquisa, a entrevista foi iniciada com a seguinte pergunta: _'No campo das suas práticas educativas, o que mudou em você do Projeto Janelas pra cá? E o que não mudou, porque você já tinha? 
A partir daí, uma escuta aberta e atenta foi criando condições favoráveis à rememoração das experiências, exposição de opiniões pessoais, expressão de sentimentos e avaliações sobre a própria trajetória profissional.

As quatro perguntas norteadoras serviram de 'guia' durante a coleta de dados, no sentido de orientarem a captação dos dados que não surgiam espontaneamente nos discursos dos sujeitos; por esta razão, elas não foram feitas na ordem em que foram formuladas. Em outras palavras, o momento da formulação, e conseqüentemente a ordem, de cada uma das perguntas foi totalmente determinado pela dinâmica da narrativa dos próprios sujeitos, daí a utilização de aspas na palavra guia.

A primeira parte do instrumento de coleta de dados compõe-se dos seguintes norteadores das narrativas dos sujeitos:

1. No campo das suas práticas educativas, o que mudou em você do Projeto Janelas pra cá? E o que não mudou, porque você já tinha?

Aspectos relevantes para observação:

$\checkmark$ Se as mudanças relatadas são internas (de atitudes, conceitos, valores) ou externas (comportamentais);

$\checkmark$ Se houve mudança de percepção acerca dos saberes e valores de classe; se afirmativo, em qual direção?

2. Fale-me (mais) sobre as suas práticas educativas de 2004 para cá.

Aspectos relevantes para observação:

$\checkmark$ Onde o entrevistado coloca a ênfase de suas experiências como educador (aquisição de conhecimentos; desenvolvimento de reflexão crítica; atividades participativas; exercício de diferentes pontos de vista; relações familiares, profissionais, de amizade e vizinhança; consciência política, participação comunitária, etc.). 
3. Descreva com mais detalhes a prática educativa que você considera ser a mais significativa.

Aspectos relevantes para observação:

$\checkmark$ Nos conteúdos manifestos e latentes do discurso; ler texto e subtexto.

4. De quais outras experiências de formação, posteriores ao Projeto Janelas, você participou como educador (a) e como educando (a)? Em quais aspectos elas foram interessantes e significativas para você?

Obs. orientar a escuta colocando foco na relação, na interação humana, cuidando sempre de não induzir o entrevistado.

Aspectos relevantes para observação:

$\checkmark$ Se por interesse ou necessidade

$\checkmark$ Se por oportunidade

$\checkmark$ Se por iniciativa própria ou estímulo de colegas, familiares ou instituição empregadora

$\checkmark$ Dificuldades e facilidades para acompanhar ou ministrar o curso / oficina de formação.

Aqui, parece oportuno elucidar que esta opção metodológica também foi possível por causa da experiência profissional anterior da pesquisadora, com sólida formação e prática psicanalítica. Suas habilidades de manejo da entrevista aberta, observação clínica e atenção flutuante (tipo de escuta psicanalítica) não são passíveis de serem aprendidas em curto espaço de tempo, na falta do que poderia ter havido um comprometimento importante do rigor metodológico deste estudo.

A segunda parte do instrumento, ao contrário da primeira, é bastante objetiva e tem por finalidade complementar a caracterização dos sujeitos através da obtenção de informações como sexo, idade, etnia, formação acadêmica e profissional. Quanto ao seu preenchimento, todos os sujeitos preferiram levar para casa e devolvê-lo através de e-mail. 
No Anexo C apresenta-se o instrumento completo. E no Anexo D, o termo de consentimento livre e esclarecido.

As entrevistas foram gravadas e integralmente transcritas. Essas transcrições foram feitas por terceiros e totalmente revisadas pela pesquisadora, de acordo com os seguintes passos:

$\checkmark$ Ouvir a gravação na íntegra preenchendo as lacunas deixadas pelo profissional que fez a transcrição;

$\checkmark$ Redigir o discurso de forma a ser inteligível, com pontuação e supressão de elementos inúteis, pois 'a transcrição do discurso oral simples, sem arranjo, não torna o discurso inteligível depois de escrito' (Guerra, 2006:70).

\subsubsection{Os sujeitos da pesquisa}

O Projeto Janelas envolveu 130 profissionais de saúde de 10 Distritos de Saúde (atualmente 09 Supervisões de Saúde), conforme seleção e critérios já expostos neste trabalho, dos quais 114 participaram das oficinas de capacitação do projeto, ocorridas entre agosto e outubro de 2003. Os ausentes foram principalmente aqueles que ocupavam cargos de gestão - gerentes de unidade e coordenadores da estratégia Saúde da Família - devido ao processo de descentralização da administração municipal em subprefeituras ter se dado justamente naquele momento, causando muita insegurança e migração de muitos para outros locais e postos de trabalho.

Os 114 'multiplicadores' qualificados eram oriundos de 68 Unidades Básicas de Saúde dos Distritos do Jardim São Luis e Jardim Ângela (Supervisão Técnica de Saúde de M’Boi Mirim), Grajaú (STS Capela do Socorro), Cidade Ademar (STS Santo Amaro/Cidade Ademar), Parelheiros (STS Parelheiros), Vila Brasilândia (STS Freguesia do Ó/Brasilândia), Sé (STS Sé), Cidade Tiradentes (STS Cidade Tiradentes), Itaquera (STS Itaquera) e São Miguel (STS Ermelino Matarazzo/São Miguel).

Desses, 98 profissionais 'multiplicadores' sustentaram algum tipo de prática educativa com as equipes e/ou as famílias, participando das reuniões da Rede de 
Multiplicadores que ocorreram de maneira regionalizada durante o ano de 2004 com freqüência bimensal: dois grupos na Região Sul (grupo Sul I - Jardim São Luiz, Jardim Ângela e Grajaú; grupo Sul II - Cidade Ademar e Parelheiros), um

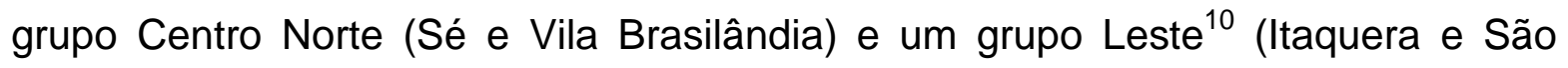
Miguel).

O mapa da implantação do Projeto Janelas oferece uma boa visão da extensão da implantação na cidade de São Paulo e pode ser encontrado no Anexo E.

Para estimular a comunicação eletrônica entre os participantes da rede e chamálos para as reuniões regionais foram organizadas quatro listas de e-mails, tendo essa comunicação funcionado bastante bem.

Portanto, a primeira abordagem dos potenciais sujeitos de pesquisa foi feita através dessas listas de e-mails, com o que foram obtidas 12 respostas (dezenove e-mails voltaram com a justificativa 'usuário desconhecido'). Essas 12 pessoas foram consideradas como potenciais sujeitos de pesquisa porque demonstraram interesse inicial importante e disposição para participarem das entrevistas. Então, uma primeira rodada de escolha dos sujeitos foi feita com base em dois critérios fundamentais: (a) não concentrar profissionais oriundos de uma mesma região da cidade ou duas, selecionando-os proporcionalmente ao quantitativo atuante por região (54 Sul x 01 Centro Oeste x 20 Leste x 23 Norte), do que resultou a proporção 2 Sul x 1 Leste x 1 Norte; e (b) dar preferência a profissionais que estavam trabalhando dentro das unidades de saúde, possibilitando assim um acesso a experiências educativas diretas e consistentes com as equipes e as famílias.

Após a realização das primeiras quatro entrevistas foi feita uma segunda rodada de escolha com base nos mesmos critérios e procedimentos, tendo sido selecionados mais quatro sujeitos de pesquisa. Por volta da quinta entrevista, o panorama das dinâmicas e conteúdos das entrevistas já apontava no sentido da saturação dos dados obtidos, pois que se repetiam.

10 A Supervisão de Saúde de Cidade Tiradentes não implantou o projeto por razões de ordem política decorrentes do processo de descentralização em subprefeituras. 
Não foi possível entrevistar dois dos oito sujeitos selecionados. Um deles marcou dia, hora e local e não compareceu. O outro não respondeu à solicitação de enviar telefone para contato direto nem foi possível encontrá-lo de outra forma.

Todos os sujeitos demonstraram interesse, empenho e grande envolvimento com a tarefa de rememorar, reconstruir e historiar sua trajetória como educadores em saúde. E assim, a coleta de dados com base em seis entrevistas foi considerada satisfatoriamente concluída.

\subsubsection{Análise de dados}

Segundo Minayo (2006), a análise de conteúdo parte de uma leitura das narrativas manifestas, podendo atingir gradativamente níveis mais aprofundados que vão além dos sentidos imediatos. Relacionando as estruturas semânticas a outros elementos contextuais significativos do ponto de vista histórico, sociológico, científico, etc., o significado das narrativas é mais profundamente desvelado. A técnica de análise temática, ao buscar descobrir esses "núcleos de sentido" subjacentes às narrativas, vai formulando suas categorias temáticas estruturais.

Para a análise das histórias de vida utilizamos a análise temática conforme apresentada por Bardin (1977), organizadas as etapas do trabalho à semelhança do que fizeram Aguiar (2001) e Trapé (2005):

$\checkmark$ Captação das histórias contando com 0 apoio de pequenas anotações durante a entrevista e sua gravação na íntegra;

$\checkmark$ Transcrição integral das gravações feita por terceiros;

$\checkmark$ Revisão das transcrições em dois passos: a) ouvindo a gravação na íntegra para preencher as lacunas deixadas pelo profissional que fez a transcrição; b) redigindo o discurso com pontuação e supressão de elementos inúteis,

$\checkmark$ Realização de 'leitura flutuante' do material para interpretar e relacionar os significados apreendidos;

$\checkmark$ Correlação entre os norteadores das narrativas (o 'guia' de pesquisa) e os discursos escritos, identificando quais trechos referem-se a quais norteadores; 
$\checkmark$ Fragmentação dos trechos escritos com vistas à construção de unidades menores de significação ('recortes'), utilizando-se cores para a identificação das categorias empíricas encontradas;

$\checkmark$ Análise de resultados à luz das categorias analíticas escolhidas.

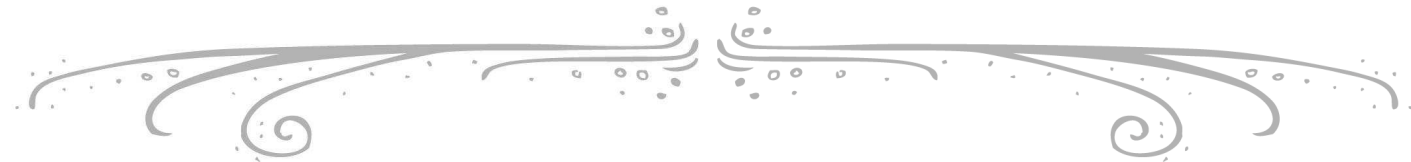




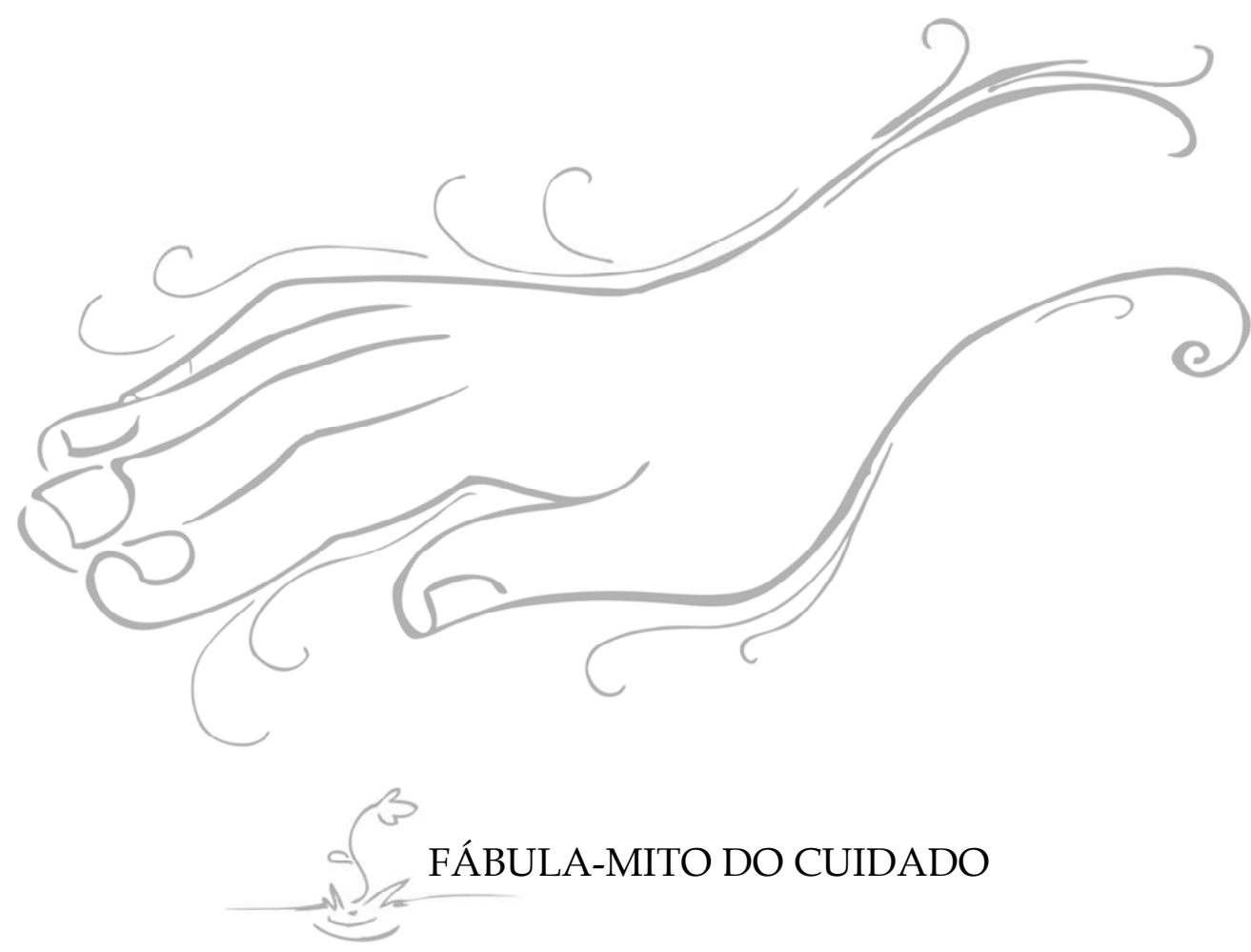

"Certo dia, ao atravessar um rio, Cuidado viu um pedaço de barro. Logo teve uma idéia inspirada. Tomou um pouco do barro e começou a dar-lhe forma. Enquanto contemplava o que havia feito, apareceu Júpiter.

Cuidado pediu-lhe que soprasse espírito nele. O que Júpiter fez de bom grado.

Quando, porém, Cuidado quis dar um nome à criatura que havia moldado, Júpiter o proibiu. Exigiu que fosse posto o seu nome.

Enquanto Júpiter e Cuidado discutiam, surgiu, de repente, a Terra. Quis também ela conferir seu nome à criatura, pois fora feita de barro, material do corpo da Terra. Originou-se então uma discussão generalizada.

De comum acordo pediram a Saturno que funcionasse como árbitro. Este tomou a seguinte decisão, que pareceu justa:

_Você, Júpiter, deu-lhe o espírito; receberá, pois, de volta este espírito por ocasião da morte dessa criatura.

Você, Terra, deu-lhe o corpo; receberá, portanto, também de volta o seu corpo quando essa criatura morrer.

Mas como você, Cuidado, foi quem, por primeiro, moldou a criatura, ela ficará sob seus cuidados enquanto viver.

E uma vez que entre vocês há uma acalorada discussão acerca do nome, decido eu: esta criatura será chamada Homem, isto é, feita de húmus, que significa terra fértil. " 


\section{Resultados e ANÁLISE}

Os resultados desta pesquisa referem-se ao desvelamento da trajetória dos sujeitos no campo das suas práticas de educação em saúde. Sua apresentação está organizada a partir de um conjunto de categorias empíricas que foram identificadas durante as sucessivas leituras do material coletado nas entrevistas. Sua análise é apresentada de forma concomitante e articulada à sua descrição, uma vez que as referências teóricas utilizadas dialogam e iluminam os discursos vivos dos sujeitos.

\subsection{Quem são os sujeitos da pesquisa}

Dos seis sujeitos entrevistados, cinco são do sexo feminino e um do sexo masculino; desses, cinco se auto-referem como sendo de raça branca e um pardomorena. Suas idades variam de 36 a 51 anos ou mais (um na faixa de 36 a 40 anos; dois na faixa de 41 a 45 anos; um na faixa de 46 a 50 anos e um com mais de 51 anos).

Todos têm escolaridade superior completa, sendo cinco deles graduados em enfermagem, um em psicologia e um em medicina.

Quanto à formação especializada, cinco sujeitos fizeram de um a três dos seguintes cursos: especialização em Saúde da Família (dois sujeitos), Enfermagem do Trabalho, Administração Hospitalar, Saúde Pública, Habilitação Médico Cirúrgica, Clínica Médica, Doenças Infecciosas e Parasitárias e Afecções Crônicas Degenerativas.

Dois deles têm mestrado, um na área de Enfermagem em Saúde Coletiva e outro na área de Doenças Infecciosas e Parasitárias. Um terceiro sujeito está cursando o mestrado na área de Educação Especial. De todo o grupo, um concluiu doutorado.

No quesito 'outros cursos', foram referidos residência em Enfermagem, qualificação em Saúde Reprodutiva, capacitação em Saúde Mental, curso sobre fundamentos teórico-metodológicos da ação educativa, curso de formação biográfica de linha antroposófica e curso de psicoterapia corporal neo-reichiana. 
Nenhum dos sujeitos fez formação especifica na área da Saúde da Criança; apenas um referiu ter feito dois cursos bastante pontuais sobre aleitamento materno e projeto Canguru.

Em 2004, ano da implantação do projeto pelos 'multiplicadores' em suas respectivas áreas de atuação, nossos sujeitos de pesquisa ocupavam os seguintes cargos: assistente de gestão de políticas públicas - antigo assistente técnicoadministrativo (um), enfermeira de equipe de SF (quatro) e médico de equipe de SF (um). Em 2009, dois deles não estavam mais trabalhando em Unidades de Saúde da Família, sendo que um foi para a Secretaria de Desenvolvimento e Ação Social (SMADS) e o outro para o projeto AMA - Atendimento Médico-Ambulatorial. As quatro enfermeiras permaneceram na função de enfermeiras de equipe, das quais três estavam nas mesmas unidades de saúde.

Todos são sujeitos estáveis em suas carreiras e bem preparados tecnicamente. Apesar de demonstrarem interesses teóricos diversos uns dos outros, pelo menos dois aspectos são comuns a pelo menos quatro deles: (1) grande interesse e experiência acumulada no campo das práticas educativas, na área da Educação ou na área da Saúde; e (2) visão ampliada de ser humano, para além do corpo físico ou biológico.

Nenhum deles referiu ter tido experiência anterior ao Projeto Janelas como 'multiplicador'; experiência posterior sim, pois foram feitas algumas referências, ainda que de pequeno peso e significação, à formação em Medicina Tradicional Chinesa (Tai-Chi-Pai-Lin) para multiplicar com as equipes de PSF; palestras em escolas, instituições parceiras e colegas de equipe; curso técnico de Agentes Comunitários de Saúde/Módulo I e Curso de Práticas Corporais.

Alguns sujeitos abordaram a descontinuidade ou interrupção do Projeto Janelas lamentando-a; outros exaltaram o processo de incorporação de novas atitudes, conhecimentos e práticas - por eles próprios e pelos profissionais das equipes independentemente das ações terem ou não tido continuidade.

- "Porque, de algum jeito, nas pessoas que realmente sentiram e vivenciaram isso, está dentro delas. Basta esquentar um pouquinho que o negócio começa de novo. [...] existem sementezinhas que a gente vai plantar e nem sabe onde e nem quem vai colher; importante é plantar porque a gente quer o bem e o melhor pras crianças e pra nós mesmos." (S5) 
Três sujeitos (S1, S5 e S6) destacaram a importância do apoio políticoadministrativo por parte da gestão e do aperfeiçoamento técnico de instrumentos e ações de monitoramento, acompanhamento e avaliação para o sucesso ou fracasso da implantação do projeto (além da formação qualificada das equipes).

- "Então, mesmo que nós tivéssemos sido tocados pelo ideal do projeto, a primeira grande tarefa não era nem multiplicar, era obter condições para multiplicar. Havia uma série de questões político-administrativas difíceis de solucionar. Eu me lembro que havia alguns coordenadores de unidades de saúde que sequer admitiam as multiplicações em suas unidades. Na verdade foram necessárias algumas batalhas para que houvesse liberação dos horários dos funcionários, disponibilização de espaço, etc." (S6)

Estes extratos de entrevista indicam que o processo instaurado pelo Projeto Janelas foi inovador e buscou ampliar as possibilidades de atuação a partir da ocupação de brechas no cotidiano das unidades e dos profissionais; e o quanto é importante investir na autonomia dos profissionais para a concretização de propostas como essa.

\subsection{O que dizem os sujeitos da pesquisa}

De suas falas foram recortadas três grandes áreas temáticas que, por sua vez, foram subdivididas em sete unidades menores ou categorias empíricas específicas.

Os grandes temas são:

Área temática I. A formação que receberam como 'multiplicadores' do Projeto Janelas;

Área temática II. As práticas educativas que desenvolveram como 'multiplicadores' do Projeto Janelas com as equipes e as famílias;

Área temática III. Percepção de impacto $^{11}$ das ações educativas com as famílias e comunidades.

11 Termo utilizado no sentido estrito de mudança 
O Relatório Delors para a UNESCO (1998) propõe um determinado tipo de educação para século XXI e apresenta os pilares do conhecimento que, desde o início desta década, vem orientando a formulação de políticas educacionais em nosso país. Trata-se de um conceito ampliado de educação que se estende para toda a vida e cujas características essenciais são a flexibilidade, a diversidade e a acessibilidade no tempo e no espaço. Conseqüentemente, a idéia de educação permanente, que interessa especialmente neste estudo, surge enquanto formação contínua para dar conta das mudanças e adaptações profissionais necessárias aos novos tempos, além de possibilitar uma construção contínua da pessoa humana, de seus saberes e aptidões, de sua capacidade de discernir e agir.

- "O conceito de educação ao longo de toda a vida aparece, pois, como uma das chaves de acesso ao século $X X I$. Ultrapassa a distinção tradicional entre educação inicial e educação permanente. Vem dar resposta ao desafio de um mundo em rápida transformação, [...] É uma exigência que continua válida e que adquiriu, até, mais razão de ser. E só ficará satisfeita quando todos aprendermos a aprender." (Relatório Delors, 1998; 19)

De acordo com esse Relatório, o século XXI ofereceria meios nunca antes disponíveis para a circulação e armazenamento de informações, de tal forma que a educação será duramente testada no sentido de vir a transmitir, de forma maciça e eficaz, cada vez mais saberes e fazeres adaptados a uma civilização de tipo cognitivo, sendo estas as bases das competências do futuro. Simultânea e contraditoriamente, a educação também deveria vir a encontrar referências capazes de impedir que as pessoas se perdessem em ondas mais ou menos efêmeras de informações, levando-as a se orientar para projetos de desenvolvimento individual e coletivo. Desta forma, uma resposta puramente quantitativa à necessidade insaciável de informação que a atualidade exige, não é mais possível nem adequada. Acumular no começo da vida (fase escolar) uma determinada quantidade de conhecimentos que irão abastecer o cidadão indefinidamente não é mais pensável, não é mais possível. Pelo contrário, do começo ao fim da vida será necessário aproveitar e explorar todas as oportunidades de atualização, aprofundamento e enriquecimento daqueles 
conhecimentos adquiridos no início da vida, na perspectiva de uma adaptação constante a um mundo em mudança. Neste contexto de análise, o Relatório Delors propõe a organização da educação em torno de quatro aprendizagens fundamentais que, de algum modo, serão os pilares do conhecimento para todos os indivíduos: aprender a conhecer, aprender a fazer, aprender a conviver e aprender a ser, sendo estas quatro vias do saber apenas uma, dado que existem entre elas múltiplos pontos de contato, intercâmbio e permuta.

Estes 'quatro pilares do conhecimento', pensados fundamentalmente para o ensino formal, estruturado, também poderão servir de referência e organização de outros tipos de experiências educativas, como é o caso do nosso estudo.

\section{Aprender a conhecer}

Trata-se de um tipo de aprendizagem que visa mais o domínio dos próprios instrumentos do conhecimento e menos a aquisição de um determinado repertório de saberes e códigos, constituindo-se assim, simultaneamente, em meio e finalidade. Meio, na medida em que se aprende a compreender o mundo ao redor para nele viver dignamente; finalidade, na medida em que implica no prazer de compreender, conhecer e descobrir esse mesmo mundo.

-"O aumento dos saberes, que permite compreender melhor o ambiente sob os seus diversos aspectos, favorece $o$ despertar da curiosidade intelectual, estimula o sentido crítico e permite compreender o real, mediante a aquisição de autonomia na capacidade de discernir. Aprender para conhecer supõe, antes tudo, aprender a aprender, exercitando a atenção, a memória e o pensamento. [...] $O$ processo de aprendizagem do conhecimento nunca está acabado, e pode enriquecer-se com qualquer experiência. Neste sentido, liga-se cada vez mais à experiência do trabalho, à medida que este se torna menos rotineiro". (Relatório Delors, 1998; 92)

Assim, 'aprender a conhecer' combina uma cultura geral com a possibilidade de trabalhar em profundidade um determinado conjunto de assuntos, o que também implica em 'aprender a aprender' para beneficiar-se das oportunidades oferecidas pela educação ao longo de toda a vida. 


\section{Aprender a fazer}

Segundo o mesmo relatório, 'aprender a conhecer' e 'aprender a fazer' são, de certa forma, indissociáveis. Entretanto, esta segunda aprendizagem estaria mais diretamente relacionada à questão da formação profissional, isto é, a como ensinar o aluno a praticar seus conhecimentos adaptando-os ao seu trabalho. Esta dimensão é especialmente importante para a área da saúde onde os profissionais que atuam nos serviços públicos se defrontam com aspectos relacionados à organização dos serviços que, muitas vezes, constituem-se em verdadeiras barreiras para a 'aplicação do conhecimento'.

No contexto das sociedades que se desenvolveram a partir do modelo industrial do século $X X$, onde a substituição gradativa do trabalho humano pelas máquinas tornou-o cada vez mais imaterial e acentuou o caráter cognitivo das tarefas, aprender a fazer não tem mais o significado simples de preparar alguém para uma determinada tarefa material, isto é, a confecção de alguma coisa, ainda que isto tenha um caráter formativo que não deve ser desprezado; a mudança essencial se expressa na alteração de ênfase na qualificação profissional pela noção de competência pessoal. Cada vez mais a exigência de uma qualificação muito ligada à idéia de competência material está sendo substituída pela exigência de uma competência que mais parece um 'coquetel' de competências combinadas, como por exemplo, a formação técnica e profissional associada ao convívio social, o trabalho em equipe, a iniciativa, o gosto pelo desafio, etc. (Relatório Delors, 1998) Assim, 'aprender a fazer' envolve não somente a aquisição de uma qualificação profissional, mas também, e de uma maneira ampla, as competências que possibilitam o enfrentamento de numerosas situações sociais e profissionais, na perspectiva do trabalho em equipe.

\section{Aprender a conviver}

Em um mundo de violência como o de hoje, um dos maiores desafios da educação é o de contribuir para a construção de relações humanas menos competitivas, mais solidárias e mais produtivas no sentido coletivo. Trata-se, portanto, de 
conceber uma educação capaz de evitar conflitos ou de resolvê-los de forma pacífica. Segundo o Relatório Delors, 'o clima geral de concorrência que caracteriza, atualmente, a atividade econômica no interior de cada país, e sobretudo em nível internacional, tem tendência de dar prioridade ao espírito de competição e ao sucesso individual'. (1998:97)

Promover a diminuição da competição significa não só colocar em comunicação membros de grupos diferentes. Essa comunicação deverá dar-se em um contexto igualitário, com vistas à conquista de objetivos e projetos comuns; 'parece, pois, que a educação deve utilizar duas vias complementares. [...] a descoberta progressiva do outro [...] e, ao longo de toda a vida, a participação em projetos comuns, [...] um método eficaz para evitar ou resolver conflitos latentes'. (1998:97)

Assim, 'aprender a conviver' significa 'aprender a viver juntos' desenvolvendo a compreensão do outro e a percepção das interdependências, realizando projetos comuns e cultivando os valores do pluralismo, da compreensão mútua e da paz. Vale acrescentar a esta definição de 'aprender a conviver' o reconhecimento pelos profissionais de saúde das relações institucionais de poder, bem como de seu empowerment no sentido de atuarem em contextos de assimetria de poder ampliando o diálogo.

\section{Aprender a ser}

Este quarto pilar do conhecimento refere-se ao desenvolvimento integral da pessoa humana. O Relatório Delors (1998) postula o desenvolvimento pleno do homem na complexidade de suas expressões e compromissos na sociedade em que vive:

-"Todo o ser humano deve ser preparado, especialmente graças à educação que recebe na juventude, para elaborar pensamentos autônomos e críticos e para formular os seus próprios juízos de valor, de modo a poder decidir, por si mesmo, como agir nas diferentes circunstâncias da vida". (Relatório Delors, 1990:100) 
Nesta perspectiva, uma grande importância deve ser dada à imaginação e à criatividade, pois elas são como que manifestações da liberdade humana, manifestações estas que devem ser protegidas de ameaças como, por exemplo, a da padronização dos comportamentos individuais.

\begin{abstract}
"Na escola, a arte e a poesia deveriam ocupar um lugar mais importante do que aquele que Ihes é concedido, em muitos países, por um ensino tornado mais utilitarista do que cultural. A preocupação em desenvolver a imaginação e a criatividade deveria, também, revalorizar a cultura oral e os conhecimentos retirados da experiência da criança ou do adulto". (Relatório Delors, 1990:100)
\end{abstract}

Assim, 'aprender a ser' significa melhor desenvolver a personalidade estando à altura do agir com autonomia, discernimento e responsabilidade pessoal, sem negligenciar potencialidades como memória, raciocínio, sentido estético, capacidades físicas e aptidão para comunicar-se. Aqui também, no campo das práticas em saúde, destaca-se a importância da autonomia dos profissionais, uma vez que se trata de perseguir a realização de um trabalho vivo de fato, conforme propõe Merhy (1997).

Estes quatro pilares da educação, apresentados e descritos no Relatório Delors para a UNESCO de 1998, extrapolam uma determinada fase da vida e um determinado lugar de aprendizagem - por exemplo, a idade escolar e a sala de aula - e por isso serviram de pilares organizadores dos achados desta pesquisa, na medida em que revelaram forte correspondência com as categorias empíricas encontradas.

O Quadro I relaciona os quatro pilares do conhecimento com as três grandes áreas temáticas identificadas (categorias empíricas maiores) e suas sete subáreas temáticas (categorias empíricas menores). 
Quadro l. Categorias empíricas encontradas e sua relação com os quatro pilares do conhecimento da UNESCO

\begin{tabular}{|c|c|c|}
\hline $\begin{array}{c}\text { Áreas temáticas } \\
\text { (categorias empíricas maiores) }\end{array}$ & $\begin{array}{c}\text { Subáreas temáticas (categorias } \\
\text { empíricas menores) }\end{array}$ & $\begin{array}{c}\text { Pilares do } \\
\text { conhecimento } \\
\text { (Relatório Delors - } \\
\text { UNESCO) }\end{array}$ \\
\hline \multirow{2}{*}{$\begin{array}{l}\text { Tema I. A formação que } \\
\text { receberam como } \\
\text { 'multiplicadores' do Projeto } \\
\text { Janelas }\end{array}$} & $\begin{array}{l}\text { Subtema 1. Aspectos significativos } \\
\text { do processo de formação }\end{array}$ & \multirow{2}{*}{$\begin{array}{l}\text { APRENDER A CONHECER } \\
\text { APRENDER A CONVIVER }\end{array}$} \\
\hline & $\begin{array}{l}\text { Subtema 2. Percepção de impacto } \\
\text { em suas próprias atitudes e } \\
\text { condutas }\end{array}$ & \\
\hline \multirow{4}{*}{$\begin{array}{l}\text { Tema II. As práticas educativas } \\
\text { que desenvolveram como } \\
\text { 'multiplicadores' do Projeto } \\
\text { Janelas com as equipes e as } \\
\text { famílias }\end{array}$} & Subtema 3. Abertura para a escuta & \multirow{4}{*}{ APRENDER A FAZER } \\
\hline & $\begin{array}{l}\text { Subtema 4. Percepção de valores } \\
\text { sociais e compreensão dos } \\
\text { determinantes sociais do processo } \\
\text { saúde-doença }\end{array}$ & \\
\hline & $\begin{array}{l}\text { Subtema } 5 \text {. Práticas emancipatórias } \\
\mathrm{x} \text { práticas regulatórias }\end{array}$ & \\
\hline & Subtema 6. Práticas intersetoriais & \\
\hline $\begin{array}{l}\text { Tema III. Percepção de impacto } \\
\text { das ações educativas com as } \\
\text { famílias e comunidades }\end{array}$ & $\begin{array}{l}\text { Subtema 7. Fortalecimento dos } \\
\text { cuidados familiares - 'famílias } \\
\text { educadoras' }\end{array}$ & $\begin{array}{l}\text { APRENDER A CONVIVER } \\
\text { APRENDER A SER }\end{array}$ \\
\hline
\end{tabular}




\subsection{1 'Aprender a conhecer' e 'Aprender a conviver': a formação recebida}

\subsubsection{Sobre a formação que receberam}

Esta categoria agrupa relatos sobre (1) a articulação das dinâmicas de grupo com os conteúdos teóricos e técnicos, numa relação de sentido e significação para a aprendizagem; (2) conteúdos novos e atuais; (3) vivências trabalhadas equilibrando e integrando as esferas do sentir, agir e pensar; e (4) a alternância equilibrada entre momentos de concentração e dispersão.

Em síntese, os sujeitos abordaram aspectos específicos desta experiência de formação que podem ser organizados em dois eixos. O primeiro refere-se à qualidade e atualidade dos conteúdos teóricos e técnicos; o segundo, aos aspectos metodológicos do processo ensino-aprendizagem.

\section{Eixo I. Conteúdos}

A importância dos primeiros anos de vida para o desenvolvimento humano posterior tem sido pouco a pouco reconhecida e, à medida que os estudos científicos avançam, vai sendo confirmada esta sua influência fundamental.

Dentre os fatores mais conhecidos estão aqueles relacionados à nutrição e ao desenvolvimento neurofisiológico:

- Todos os tecidos, sangue, cérebro e ossos da criança são formados durante o período que vai da concepção aos três anos de idade.

- O desenvolvimento humano durante os primeiros 18 meses é tão rápido que o estado nutricional das gestantes, lactantes e crianças pequenas é da maior importância neste período.

- Uma nutrição inadequada antes do nascimento e nos primeiros anos de vida pode afetar seriamente o desenvolvimento do cérebro, causando distúrbios neurológicos, atrasos e dificuldades nos processos de aprendizagem.

(São Paulo, 2003; Chiesa, Veríssimo, Fracolli, 2009)

Os estudos de neurociência das últimas décadas, ao demonstrarem como o cérebro humano infantil depende de estimulação adequada do meio ambiente para 
se desenvolver, contestam as velhas concepções centradas em sua determinação genética.

\begin{abstract}
- "[...] o impacto do ambiente é dramático e específico, não somente influenciando a direção geral do desenvolvimento, como realmente afetando a forma como o circuito intricado do cérebro humano é montado" (Shore, 2000).
\end{abstract}

Assim, os cuidados essenciais durante os primeiros anos de vida - especialmente os três primeiros anos - têm impacto decisivo e duradouro sobre o desenvolvimento infantil de um modo geral e sobre a capacidade da criança de aprender e lidar com suas emoções.

Esses estudos também identificaram que, junto com essa capacidade geral notável de transformação, o desenvolvimento do cérebro passa por períodos críticos durante os quais determinados aprendizados são mais favorecidos, isto é, dão-se de maneira mais 'fácil'. A esses períodos críticos e de maior potencial de resposta da criança, os neurocientistas deram o nome de 'janelas de oportunidades'.

S2. Aí vem a questão do vínculo, vem a questão do estímulo, do estímulo positivo, do estímulo negativo, como que começa a preparar a questão do vínculo através da barriga, como nasce uma criança, e vem muitos conceitos do 'Janelas'. Que uma criança não nasce pronta... daí a gente fala de uma criança que não tenha problemas de má formação, que não tenha nada, que o cerebrozinho dela está pronto, mas que precisa começar a fazer as ligações [sinapses].

[...] A gente fala das 'janelinhas', que com a estimulação, dependendo do que a criança está experimentando, vão se abrindo algumas 'janelinhas', que no futuro vão ajudar na escola, vão ajudar nisso, naquilo, no vínculo com as pessoas, num monte de coisas.

S3. [com o Projeto Janelas] a gente aprendeu muita coisa, que é aquela questão da atenção direcionada para aquela faixa de vida, aquele período de vida onde está formando as sinapses!

[...] O estímulo, o quanto o estímulo é importante! Que a criança aprende vendo, ela copia, imita o adulto, não é assim? Da responsabilidade que a gente tem enquanto formação, enquanto formador de opinião, não só dos profissionais, mas das mães também, dos cuidadores enfim. 
S5. [a neurociência] que um bebê ou um feto já está recebendo todas essas emoções que a mãe vive, que passam a fazer parte dessa criança pro resto da vida também, isso foi um foco que me chamou muito a atenção.

S6. [...] o período mais importante da formação da criança, desde o pré-natal ou até mesmo o período da concepção, da pré-concepção, passando pelo pré-natal, e os três primeiros anos que duram para sempre.

[...] É como se, na verdade, você tivesse encontrado uma pérola ou um grande segredo - esse grande segredo de que os primeiros anos são para sempre - e tem a tarefa de disseminar esse segredo.

Nestes trechos de discursos sobre o tema em análise já aparece uma forte ênfase na qualidade do vínculo do cuidador com a criança, vínculo esse que é de natureza essencialmente afetiva, uma atenção amorosa capaz de gerar segurança e confiança.

Durante a primeira infância, o cuidador mais importante para a criança é a sua família. Cabe à família a responsabilidade pelo atendimento das necessidades essenciais da criança e pela oferta de oportunidades que promovam o seu desenvolvimento físico, mental, emocional e social. E cabe às políticas públicas apoiarem as famílias nessa tarefa, especialmente aquelas famílias socialmente mais vulneráveis.

Os instrumentos do Projeto Janelas - a cartilha da família e o manual de apoio da equipe de saúde - abordam os cuidados infantis com alimentação, higiene, prevenção de acidentes, amor e segurança, brincadeiras, direito e participação da criança, apoiando-se nas seguintes vertentes:

- A importância dos cuidados familiares para o desenvolvimento da criança;

- A rotina como elemento estruturador da estimulação da criança;

- As experiências e oportunidades que a família oferece que facilitam as conquistas da criança.

(São Paulo, 2003; Chiesa, Veríssimo, Fracolli, 2009)

Neste contexto, o conceito de resiliência tem grande relevância, o que é corroborado pelas falas dos sujeitos, conforme apresentamos mais adiante. 
De acordo com Chiesa (2005), a discussão sobre resiliência requer a recuperação do seu entendimento como um fenômeno que se caracteriza por obter resultados positivos na presença de situações adversas. As condições facilitadoras da promoção da resiliência compreendem diversos aspectos relativos ao patrimônio das relações sociais.

A autora indica que, na dimensão singular da realidade - dimensão dos indivíduos e das famílias - destaca-se a coesão familiar, a proximidade de relação dos pais com os filhos e seu maior envolvimento com a educação e a vida social deles, tudo isso permeado pela afetividade, reciprocidade e melhor distribuição de poder nas relações entre eles, lembrando que pais não são apenas aqueles biológicos, mas também as pessoas que assumem responsabilidades maternas e paternas nos diversos arranjos familiares.

Na dimensão particular - dimensão da inserção social das famílias no sistema de reprodução social - a promoção da resiliência refere-se à atuação das instituições de caráter público ou privado que contribuem no processo de socialização da criança, como por exemplo, a creche e a pré-escola.

Finalmente, na dimensão estrutural, a autora relaciona a promoção da resiliência com a influência da ideologia e da luta pela efetivação dos direitos e de políticas públicas saudáveis.

Conhecimentos científicos e técnicos como esses - os achados da neurociência e o manejo da estimulação precoce com vistas ao fortalecimento da resiliência da criança - são elementos fundamentais, mas insuficientes, na formação dos profissionais de saúde, especialmente aqueles que atuam na atenção básica. São as tecnologias leve e leve/dura que, segundo Merhy (1997), mais demandam conhecimentos e habilidades relacionais centradas no cuidado, na escuta e na reflexão sobre os determinantes sociais do processo saúde-doença, para o que os profissionais de saúde precisam urgentemente ser formados. 
Um terceiro elemento indispensável na aproximação a esse ideal formativo é apontado por Reyes, Abalo e Labrada (1999) e diz respeito à importância da vontade política dos governos no sentido de defenderem e sustentarem iniciativas orientadas para esse tipo de formação profissional.

S2. [...] Aí elas [as gestantes] vão trazendo - o amor, carinho, o cuidado com a higiene, essa coisa mesma do vinculo, das relações, é onde elas começam a perceber a importância de conversar com o bebê dentro da barriga, de pensar nomes. [...] Mães melhor preparadas, filhos melhores, mais resilientes.

S5. [...] sabemos que tem crianças que conseguem muito bem sobreviver em situações muito difíceis - a resiliência que a gente aprendeu no 'Janelas' - crianças e gestantes que conseguem superar tão bem uma situação tão difícil.

Toda pessoa pertence a um determinado micro contexto relacional que é a família, que se constitui como primeiro lugar de pertença, onde a pessoa recebe um nome e vai construindo uma identidade, a partir da qual se relaciona com outras pessoas. Nos relacionamentos familiares, a pessoa 'entra com a totalidade de sua existência, de seu temperamento, de suas capacidades e limites, diferentemente do que acontece com quase todos os outros ambientes da vida, nos quais se estabelecem relações parciais, limitadas a capacidades específicas, correspondentes a funções determinadas'. (Petrini \& Alcântara, 2001, p. 3 e 4)

Assim, a família constitui-se em uma rede de solidariedade, quase sempre eficaz para oferecer os cuidados necessários a seus membros, especialmente quando eles apresentam incapacidade temporária ou permanente de prover autonomamente suas necessidades, como nos casos de crianças, idosos, enfermidades físicas (ou psíquicas) ou, ainda, desemprego. (Sanicola,1996)

Toda família possui um determinado conjunto de recursos materiais e imateriais para cuidar de si e de seus membros, recursos esses que raramente são percebidos por ela como um patrimônio, isto é, como seu bem valioso.

O conceito de patrimônio da família refere-se a um conjunto de recursos dos quais as pessoas podem dispor para garantirem, a si mesmas e a seus familiares, maior 
segurança e melhor padrão de vida. Tais recursos compõem-se de trabalho, saúde, educação, moradia, habilidades pessoais e relacionais - relacionamentos familiares, de vizinhança, de amizade, comunitários e institucionais (PIDMU, 2000).

Um dos patrimônios mais importantes da família é a sua rede social. As redes sociais participam de maneira importante da construção da identidade dos membros da família, isto é, da construção de hábitos, costumes, crenças e valores que thes conferem determinadas características. Das redes sociais, a pessoa e/ou família recebe sustento emocional, ajuda material, serviços e informações. Os diferentes tipos de redes sociais dependem de como elas se estruturam e quais bens nelas circulam; se as relações que ocorrem dentro delas baseiam-se em troca, direito, dinheiro, etc. (Solymos, Maricondi, Soares, 2009).

S1. Então, aquele momento serviu como um disparador mesmo de reflexão. E hoje, quando eu vou para os serviços, eu vivencio ainda muito daquilo que a gente discutiu lá atrás, seja na questão do que são as famílias hoje, seja nas questões sociais, muito embora tenha sido uma capacitação para a área da Saúde, eu acho que a gente peneirou e entrou por várias vezes, não dá para dissociar, nas questões sociais. Hoje, a gente tenta de toda forma articular a rede.

S5. [o projeto 'Janelas'] abriu todo aquele horizonte de como é que são essas famílias, como é que são as redes sociais - eu nem sabia direito o que é rede, rede social também - como que essas pessoas vivem, interagem, como que elas sentem, vivenciam essa mudança toda de uma criança dentro da família.

S6. [...] Até mesmo porque o que se discute em relação a família e rede social não serve apenas para a infância, embora a criança fosse o nosso objeto de atenção. $\mathrm{Na}$ verdade, isso você leva para a vida inteira. [...] Aliás, eu acho que a multiplicação enfatizava isso [...] nos trabalhos de rede, [que] nós buscássemos exemplos cotidianos nossos; nós éramos levados a buscar exemplos em nossa própria comunidade, aquela de onde nós nos originávamos: a quem pediríamos uma xícara de açúcar ou um pouco de café. Isso já colocava a experiência muito além do cuidado com a criança. 
Eixo II. Metodologia

Partindo da análise de diversos documentos, Oliveira (2007) buscou caracterizar a abordagem metodológica utilizada nas oficinas de formação do Projeto Janelas.

"[...] houve ênfase no emprego das vertentes emancipatórias da educação e a adoção de características positivas das outras tendências tecnicista/comportamentalista e construtivista/humanista com ênfase na negação da transmissão de informações e posturas impositivas e/ou coercitivas durante o processo educativo, pois além da apreensão conceitual, as oficinas objetivavam a reprodutibilidade dos recursos didáticos e metodologias pelos multiplicadores em seus respectivos locais de atuação". (Oliveira, 2007:91)

Com base no referencial freireano, o autor relacionou aspectos técnicos e metodológicos da formação dada pelo Projeto Janelas às seguintes características da vertente emancipatória da educação: (1) autonomia e liberdade dos sujeitos; (2) bem querer aos educandos; (3) complementaridade objetiva e subjetiva; (4) compromisso com a mudança; (5) educação permanente dos seres humanos; (6) horizontalidade das relações de poder; (7) práxis dialógica; e (8) reflexão crítica da realidade. (Oliveira, 2007:93)

Nos discursos dos sujeitos de pesquisa foi possível identificar afinidades importantes com as tendências indicadas por Oliveira (2007), como as que se seguem:

(1) não há docência sem discência: _Eu diria que havia questões subliminares, implícitas, na proposta da oficina que era formar-se e, ao mesmo tempo, formar-se para formar. Formar-se a si mesmo e, imediatamente, formar-se para formar, já que no final da capacitação a gente teria que produzir um modelo de multiplicação.

(2) educar 'não é transferir conhecimento, mas criar as possibilidades para a sua própria produção ou a sua construção' (Freire, 2007: p. 47): _ [...] porque não se tratava apenas de verificar conteúdos, mas de incorporá-los às nossas práticas. 
[...] Essa questão do incorporar, ele serve como ensinamento pra você mesmo, porque você muda o seu conceito de vida.

(3) a prática educativa progressista implica em uma permanente reflexão crítica sobre si mesma: _ Então você vai caminhando naquele mundinho e não vai refletindo muito sobre as coisas que estão aí à tua volta. [...] E aí cai a ficha. Opa, o modelo mudou! Eu acho que a gente já sabe, mas a gente não discute.

(4) o diálogo entre teoria e prática é permanente e se dá na perspectiva da construção de uma práxis dialógica: _ [...] Então, talvez, a natureza da experiência de formação com essa metodologia seja diferenciada mesmo, porque na hora em que você pode de imediato associar prática e teoria, eu acredito que isso se torna verdade, uma verdade provavelmente útil, porque ela vai interferir na qualidade da atenção que você presta ao seu paciente, ao usuário, a criança ou a família.

Em síntese, os principais aspectos metodológicos destacados pelos sujeitos de pesquisa foram: a relação equilibrada e articulada entre dinâmicas de grupo e conteúdos teóricos, a alternância entre momentos de concentração e momentos de dispersão e a importância de uma formação (aprender a aprender) direcionada para a prática (aprender a fazer).

S1. [...] em muitas capacitações que a gente participa eu acho que há um uso excessivo dessas dinâmicas e que acaba sendo uma chatice mesmo. E lá, o que eu gostava muito, é que a gente tinha vivência, mas a gente tinha conteúdo teórico, e isso para mim é muito importante, atrelar uma coisa a outra, né?

S6. [...] a capacitação se dava com uma carga horária que permitia a dispersão, e imediatamente você podia verificar a aplicação dos conteúdos teóricos, bastava que você fosse a uma visita domiciliar, que se dava nos núcleos populacionais, geralmente na periferia; bastava que você adentrasse as vielas desses núcleos populacionais para, imediatamente, conseguir fazer associações entre os conteúdos da própria multiplicação, que estavam fresquinhos, e a realidade que se encontrava.

S1. [...] Porque a partir do momento em que você muda o seu olhar, você muda a forma de você entender e enxergar as pessoas, as situações, o modelo que está 
posto aí, você também muda o seu modo de agir, a sua postura em relação ao outro, em relação a determinados encaminhamentos que você faz.

Ainda no sentido de elucidar conteúdos de entrevistas relacionados ao eixo Metodologia, no Quadro II são apresentados aspectos relevantes para a sistematização de processos de formação de profissionais para atuarem com ações educativas. 
Quadro II. Aspectos metodológicos relevantes para a sistematização de processos de formação de profissionais para atuarem com ações educativas

\begin{tabular}{|c|c|}
\hline Aspectos metodológicos & Descrição \\
\hline \multirow{2}{*}{ Objetivos } & $\begin{array}{l}\text { 1. Sensibilizar os 'agentes multiplicadores' para a criação de um } \\
\text { espaço de capacitação dinâmico, criativo e participativo para o } \\
\text { trabalho em equipe; }\end{array}$ \\
\hline & $\begin{array}{l}\text { 'Multiplicar' os conceitos da capacitação no cotidiano dos } \\
\text { serviços de saúde a fim de introduzir, de forma competente e } \\
\text { motivada, a cartilha da família Toda hora é hora de cuidar e a } \\
\text { ficha de acompanhamento dos cuidados para a promoção da } \\
\text { saúde da criança (utilização pelo enfermeiro e pelo médico). }\end{array}$ \\
\hline Ambiente físico & $\begin{array}{l}\text { Sala ampla com cadeiras em círculo e ambiente externo que } \\
\text { permita contato com a natureza; salas menores para trabalho } \\
\text { em pequenos grupos. } \\
\text { Ambientes claros e agradáveis. }\end{array}$ \\
\hline Facilitadores & $\begin{array}{l}\text { Equipe multiprofissional (duas enfermeiras, uma psicóloga, duas } \\
\text { assistentes sociais e uma administradora). }\end{array}$ \\
\hline $\begin{array}{l}\text { Carga horária e freqüência dos } \\
\text { encontros }\end{array}$ & $\begin{array}{l}40 \text { horas distribuídas em cinco encontros semanais de } 8 \text { horas } \\
\text { cada um, ocorrendo a dispersão a intervalos de uma semana. }\end{array}$ \\
\hline Metodologia & $\begin{array}{l}\text { Participativa e problematizadora, através da construção coletiva } \\
\text { do conhecimento nos momentos de concentração e da } \\
\text { experimentação prática no serviço e na comunidade nos } \\
\text { momentos de dispersão. }\end{array}$ \\
\hline Atividades principais & $\begin{array}{l}\text { - Acolhimento e integração dos participantes (técnica do } \\
\text { cochicho/história do nome; técnica da flor); } \\
\text { - Exposições dialogadas seguidas de debate; leituras } \\
\text { compartilhadas e comentadas; músicas e filmes seguidos de } \\
\text { debate; elaboração coletiva de cartazes seguida de debate; } \\
\text { - Dinâmicas de grupo introdutórias aos novos temas; } \\
\text { - Exercícios para relaxar e 'acordar', conforme o caso; } \\
\text { - Avaliações coletivas feitas de forma lúdica. }\end{array}$ \\
\hline
\end{tabular}

Fonte: adaptado de Oliveira (2007:89) - Quadro III - Elementos do processo de capacitação do Projeto Janelas 
A preparação da 'multiplicação', ou seja, o planejamento da formação dos profissionais das equipes de saúde foi oportunizado dentro da própria oficina de capacitação, possibilitando assim a percepção clara da metodologia empregada por parte dos participantes, a elaboração de um planejamento adaptado às realidades locais, com uma carga horária condizente com os interesses e limites dos gestores e profissionais das equipes. Além disso, a motivação, a disponibilidade de tempo e a dedicação dos 'multiplicadores' foram percebidas como elementos importantes neste processo. A criação de um ambiente favorável ao aprendizado através de práticas de cuidado com o ambiente físico, alimentação, práticas grupais facilitadoras da integração social e da motivação para aprender foram percebidas como parte integrante da metodologia adotada.

S1. Eu me lembro muito do 'Janelas', tanto é que eu tenho todo o material guardado, inclusive as folhinhas com os planejamentos, eu tenho tudo muito guardado, e me ajudou inclusive nisso, porque muito embora eu tenha sido professora, e a gente tem aquele modelo da escola, de fazer os semanários, é tudo muito seco, conteúdo tal, aplicar dessa forma - esse era o modelo que eu tinha - eu uso aquele modelo até hoje, quando eu preciso desenvolver qualquer coisa.

[...] Quando eu te falo que consigo perceber essa diferença dos modelos de capacitação, eu acho que não é somente pelo fato de ser psicóloga ou não, porque as pessoas são capazes de fazer as coisas, mas eu alio isso ao fato de que talvez eu estivesse mais disponível também em termos de tempo, né?

S2. Então, tanto desde que eu estou no PSF, tanto depois com o 'Janelas', isso me trouxe uma estruturação.

S6. [...] o modelo de capacitação parece ser fundamental, porque talvez o registro que tenha ficado tenha sido o de bem estar. [...] O bem estar como uma forma de criar raiz. E enraizar na memória o que fica dos encontros está muito associado a bem estar.

[...] A idéia era que nós contaminássemos as pessoas com a mesma energia que nós havíamos sido contaminados, e que seria a de olhar as crianças em suas necessidades principais. 


\subsubsection{Sobre a percepção de impacto em suas próprias atitudes e condutas}

A percepção dos sujeitos em relação às suas próprias mudanças internas e de comportamento foi tão marcante em seus relatos que elas se constituíram em uma categoria separada dentro da área temática em análise.

Foram ressaltadas mudanças de atitudes tais como aumento da autoconfiança, aumento do próprio interesse e motivação pelo desenvolvimento infantil (inclui os próprios filhos), maior segurança interna para empreender ações educativas no sentido da mudança; e mudanças de comportamento tanto no sentido de vincularse afetivamente e contaminar positivamente os outros quanto de conquistar legitimidade e espaços de atuação como educador (a) em saúde.

S1. Eu saí de lá super feliz, isso me deu gás, uma autoconfiança, porque o pessoal ficou o dia todo lá, foi possível prender a atenção das pessoas, foi um despertar de interesses. Eu usei muito as dinâmicas que nós usamos na capacitação e as pessoas se envolveram mesmo, participaram, deu um suporte legal para as discussões, e foi meio que um despertar pra certas pessoas que vão ficando aí... e eu saí um pouquinho desse lugar de ATA quando terminou.

S3. Então isso, não só para mim, mas quando eu multipliquei, eu senti que isso despertou muito nos profissionais [também].

[...] Eu acho que teve uma mudança em toda a vida da gente, sabia? Eu me lembro muito bem de quando a gente foi multiplicar, inclusive o pessoal do Pólo de Capacitação que falava assim:_'Meu Deus, se eu tivesse que criar meus filhos hoje, olha o quanto eu estou aprendendo'

[...] Essa questão do incorporar, ele serve como ensinamento pra você mesmo, porque você muda o seu conceito de vida.

[...] Eu acho que a coisa que mais ficou foi quando nós multiplicamos; foi uma coisa de acordar leões, sabe aquela coisa de leão adormecido? (despertar de interesses)

[...] Quem vivenciou, quem incorporou, fala e vai continuar falando.

S4. Acho que o importante do 'Janelas' é que ele foi um projeto de sensibilização, que eu aprendi tanto para a carreira profissional como para a vida pessoal [...] Eu não esqueço da cartilha, da história do 'Nó do Afeto'. 
[...] E a partir do 'Janelas' eu aprendi que eu precisava parar um pouco pra minha filha; é um pouco da empatia, de você se por no lugar do outro.

O conceito de empowerment é um conceito estruturante da Promoção da Saúde e tem como foco de análise as transformações das práticas dos indivíduos e dos grupos nesse campo.

Carvalho e Gastaldo (2008) localizam a origem do conceito e das estratégias de empoderamento na psicologia comunitária, nos movimentos de auto-ajuda e, em especial, nas práticas sociais surgidas a partir das reivindicações e lutas dos novos movimentos sociais ocorridas nas décadas de 60 a 80, sendo Paulo Freire um dos principais teóricos inspiradores de uma parcela da literatura científica comprometida com a mudança social e o fortalecimento de práticas cidadãs questionadoras do status quo.

"Empowerment' é um conceito complexo que toma emprestado noções de distintos campos de conhecimento. $\dot{E}$ uma idéia que tem raízes nas lutas pelos direitos civis, no movimento feminista e na ideologia da 'ação social' presentes nas sociedades dos países desenvolvidos na segunda metade do século XX. Nos anos 70, este conceito é influenciado pelos movimentos de auto-ajuda e, nos 80 , pela psicologia comunitária. Na década de 90 recebe o influxo de movimentos que buscam afirmar o direito da cidadania sobre distintas esferas da vida social entre as quais a prática médica, a educação em saúde e o ambiente físico" (Carvalho, 2004: 1090).

Para Chiesa (2005) é de fundamental importância trabalhar com esse conceito a partir de autores que abordam as teorias de poder na perspectiva do 'poder com' em lugar do 'poder sobre'. A autora indica também que é possível identificar manifestações de empowerment não apenas da população, mas também dos profissionais de saúde.

Carvalho (2004) define empowerment como um processo através do qual os indivíduos e coletivos aumentam seu controle sobre os determinantes sociais da saúde para desta forma melhorarem sua saúde. E apresenta suas duas faces: a individual ou psicológica e a coletiva ou comunitária. 
"Podemos definir o "empowerment" psicológico como um sentimento de maior controle sobre a própria vida que os indivíduos experimentam através do pertencimento a distintos grupos, e que pode ocorrer sem que haja necessidade de que as pessoas participem de ações políticas coletivas" (Carvalho, 2004: 1090).

Estas duas faces ou acepções não se opõem, pelo contrário, complementam-se.

"Tomando como referência a produção de autores como Julian Rappaport, importante teórico do movimento da psicologia comunitária, Paulo Freire, educador brasileiro, e Saul Alinsky, ativista social norte-americano, estudiosos anglo-saxônicos vêm propondo a noção alternativa de 'empowerment' comunitário como um elemento-chave de politização das estratégias da Nova Promoção à Saúde. No processo de ressignificação e repolitização do sentido do 'empowerment', esta abordagem trabalha com a noção de poder enquanto um recurso, material e não material, distribuído de forma desigual na sociedade, como uma categoria conflitiva na qual convivem dimensões produtivas, potencialmente criativas e instituintes, com elementos de conservação do status quo. Para os teóricos do 'empowerment' comunitário, a sociedade é constituída de diferentes grupos de interesses que possuem níveis diferenciados de poder e de controle sobre os recursos, fazendo com que processos de 'empowerment' impliquem, muitas vezes, a redistribuição de poder e a resistência daqueles que o perdem" (Carvalho, 2004: 1091).

Carvalho e Gastaldo (2008) não negam a eficácia pontual do processo de empoderamento psicológico para a produção de saúde; entretanto, avaliam que ele seria insuficiente no sentido de instrumentalizar práticas que visem alterar a distribuição de poder e de recursos na sociedade, podendo desta forma tornar-se mais um mecanismo de regulação e controle social do que de emancipação. Neste texto, os autores utilizam o termo empoderamento desde uma perspectiva críticosocial.

Portanto, desde uma perspectiva crítico-social, trata-se de construir práticas em saúde que facilitem ganhos de consciência e de poder pelos próprios sujeitos, com eles e não para eles. 
Utilizemos, pois, o verbo 'empoderar' - um neologismo - como verbo reflexivo conjugado com o pronome oblíquo átono ${ }^{12}$. Assim, 'empoderar-se' passa a significar uma ação de ganho de poder pelo próprio sujeito, na medida em que é ação reflexiva, isto é, que decorre e ao mesmo tempo recai sobre ele. Em outras palavras, 'empoderar-se' refere e marca uma ação de poder do sujeito sobre ele mesmo.

Retomando os discursos vivos dos nossos sujeitos de pesquisa é possível identificar ganhos de consciência e de poder no sentido do 'empoderar-se'? A resposta está nos extratos de entrevistas que seguem.

S2. O 'Janelas' trouxe a organização de idéias que em alguns momentos parecia que eu queria colocar na minha prática, mas não tinha uma coisa pronta, parece que não tinha uma coisa autorizada. É como se o 'Janelas' tivesse me autorizado a trazer conteúdos pra minha pratica que pra mim já eram muito importantes: a questão da humanização, a questão do afeto, a questão do vínculo que em alguns momentos eu até poderia ter trazido, porque eu já sou formada há muitos anos e, na época da minha formação, a questão que era exigida de nós, alunos de enfermagem, era uma postura emocional que não se envolvesse com o paciente.

[...] Então, parece que a sua formação já te desautorizava a trabalhar conteúdos que parece que não fazem parte da saúde, o que na minha visão não era... não combinava com a minha experiência de vida, com a construção de um trabalho que a gente quer fazer, e aí eu acho que tanto o PSF como o Projeto 'Janelas' trouxeram uma autorização...

[...] Aí eu comecei a oferecer vagas pra algumas equipes que eram mais abertas e essas equipes começaram a mandar. Enquanto isso, os enfermeiros foram crescendo, evoluindo também, então hoje o grupo não é só mais da equipe $B$. $O$ grupo de gestantes é da UBS...

[...] Sim, tô ganhando adesão dos colegas agora, mas a minha equipe aderiu desde quando eu cheguei aqui e trouxe a experiência do grupo que eles começaram comigo, [meus] agentes comunitários, auxiliares de enfermagem, eles participam disso.

\footnotetext{
${ }^{12}$ Verbos reflexivos são verbos que se conjugam com pronomes oblíquos átonos (me, te, se, lhe, nos, vos, se, lhes) que não fazem parte intrínseca do verbo - por exemplo, banhar-se, vestir-se. Verbos pronomiais, pelo contrário, são verbos que se conjugam com pronomes oblíquos átonos que fazem parte intrínseca do verbo por exemplo, zangar-se, indignar-se.
} 
S5. E quando a gente quer que alguma coisa dê certo, a gente puxa por aqueles que se envolveram! E eu sou muito assim (risos). Eu tenho muita paixão por esse programa todo, então, eu só vejo aquelas pessoas que se envolveram.

\subsection{2 'Aprender a fazer’: as práticas educativas desenvolvidas}

\subsubsection{Abertura para a escuta}

Esta categoria reúne conteúdos relacionados à importância que os sujeitos de pesquisa deram à escuta, ao estabelecimento de vínculos afetivos e aos ambientes acolhedores no sentido do diálogo e da troca de experiências de caráter pessoal.

Assim, a escuta ganha valor de cuidado e, nesta perspectiva, tem posição privilegiada tanto no campo da formação quanto no da prestação de serviços em saúde. Além disso, a escuta como cuidado poderia ser tomada como indicador sensível de mudança de paradigma nestes tempos pós-modernos, uma vez que se contrapõe ao paradigma da ciência moderna positivista - ainda dominante segundo o qual: (1) conhecer significa quantificar, o que desqualifica as qualidades intrínsecas do objeto; e (2) conhecer significa dividir e classificar, o que reduz a complexidade do mundo (Santos, 2005).

O poema de Manoel de Barros é um alerta acerca da aridez da ciência positivista, da busca do conhecimento sem encantamento. A escuta qualificada, porque se apóia simultaneamente na sensibilidade e no marco teórico de referência do sujeito que ouve, contempla os cantos e encantos do sabiá. E... 'os sabiás divinam'.

Diferentes abordagens de cuidado apóiam-se em diferentes conceitos de escuta.

Barbier (2002) caracteriza a 'escuta sensível' como um tipo de escuta bastante apropriada ao trabalho do pesquisador e do educador. Segundo ele, trata-se de um 'escutar-ver' bastante influenciado pela abordagem rogeriana em ciências humanas, pois que se apóia na empatia. Ter empatia significa ser capaz de sentir o universo afetivo, imaginário e cognitivo do outro para poder então compreendê-lo dentro de suas próprias atitudes, comportamentos e sistema de idéias. 
S5. [...] Então, numa situação dessas, é ouvir, entender um pouquinho o que essa mãe está trazendo; onde está, nas entrelinhas, o que ela realmente está precisando, e que não é aquele paracetamol para aquela dor de cabeça.

S6. Essa talvez seja uma grande lição que tenha ficado da capacitação. É a de que o cuidar abre portas. E esse cuidar pode, quem sabe, até ampliar a empatia ou iniciar a empatia por alguns temas.

O ouvinte sensível não julga, não mede, não compara. Sua compreensão ocorre sem adesão ou identificação com o que ouve e vê no outro. Neste sentido, sua escuta afirma a sua congruência, pois ele transmite suas emoções, seu imaginário, suas interrogações e até seus ressentimentos. Afirma também sua presença ou consistência, podendo se recusar a trabalhar com alguém ou grupo sob certas condições que firam seus valores e filosofia de vida.

S2. Nós não estamos condenando o fato delas [as gestantes] não estarem querendo [o bebê], mas sim apoiando, aceitando, recebendo aquilo, entendendo o momento delas.

[...] você pode apoiar através das suas orientações, apoiar de várias formas, mas que nós não estamos aqui pra criticar nem pra julgar. Então, isso faz a diferença do olhar.

S5. [...] aprende-se a ouvir muito mais, e essa interação toda das crianças com a família.

[...] Então, numa situação dessas, é ouvir, entender um pouquinho o que essa mãe está trazendo; onde está, nas entrelinhas, o que ela realmente está precisando, e que não é aquele paracetamol para aquela dor de cabeça.

Este autor também caracteriza a 'escuta sensível' através do que ela não é:

1. A escuta sensível não é uma rotulagem social - para além dos papéis e rótulos sociais, o ouvinte sensível aprecia o lugar diferenciado que cada um ocupa no campo das relações sociais, o que Ihe possibilita ouvir a palavra criadora.

2. A escuta sensível não é uma projeção de nossas angústias ou desejos - nada fácil, mas possível a partir de um trabalho consigo mesmo, envolvendo até, se for o caso, um terceiro ouvinte (um psicanalista ou psicoterapeuta, por exemplo). 
3. A escuta sensível não se fixa na interpretação de fatos - trata-se de não interpretar porque todo e qualquer julgamento foi suspenso. Nesta condição tornase possível surpreender-se frente o desconhecido e agüentar zonas de incerteza para depois arriscar algumas proposições interpretativas, já que a confiança está assegurada.

4. A escuta sensível não se apóia em apenas um órgão dos sentidos - pelo contrário, mesmo sendo escuta ela se amplia para todos os outros sentidos.

Figueiredo (2009) estuda as dimensões do cuidado partindo da análise dos modos como um agente cuidador cuida. Ele chama a nossa atenção para o fato de um agente de cuidados ser um sujeito implicado que faz coisas e que é facilmente reconhecido por esse seu fazer. E que, por outro lado, esse cuidar também pode ocorrer como uma 'presença em reserva'.

Como modalidades de 'presença implicada', o autor aponta:

1. Sustentar e conter - duas funções primordiais são importantes durante toda a nossa existência: a função de holding (Winnicott) que significa sustentação e nos garante a continuidade; e a função de containing (Bion) que nos possibilita a transformação. Famílias, grupos e instituições oferecem holding aos indivíduos ao longo de toda a sua vida. Por outro lado, para crescer e se expandir no mundo, os indivíduos também precisam de containing (continência), também oferecida pelas famílias, grupos e instituições. Estas são formas extraordinariamente importantes do cuidar. Quando elas faltam, ocorre uma sobrecarga de experiências emocionais obscuras e perturbadoras. Assim, tanto para a experiência da continuidade quanto para a da transformação, a 'presença implicada' do outro é indispensável.

S1. Então, eles traziam muitas angustias, e aí a gente percebeu que no primeiro e no segundo encontros eles precisavam falar, falar dessas angústias.

[...] quando eu comecei a captar que essa angustia precisava ser ouvida, que a gente precisava refletir sobre isso, e a gente foi permitindo.

S6. Durante a conversa com a mãe, eu olhava pra criança e percebia algo que não era ainda pra mim conhecido; eu me lembro então que, como eu estava sentado 
de frente pra essa criança, eu apenas bati na minha perna e, pra minha surpresa, a criança pulou no meu colo!

2. Reconhecer - muitas vezes cuidar é simplesmente ser capaz de prestar atenção e reconhecer o outro - o objeto dos cuidados - no que ele tem de mais próprio e singular, dando-Ihe testemunho disso, o que funciona como um retorno ao sujeito de sua própria imagem. É uma modalidade tão discreta que pode passar despercebida. Entretanto, a sua falta é extremamente prejudicial à formação da auto-estima.

S6. Eu imagino que se não estivéssemos atentos ao luto que essa criança estava vivendo e se não pudéssemos externar a nossa preocupação em relação a esse luto, talvez ela não pudesse vivenciar a sua tristeza com a força que uma criança tem de se recuperar - com a sua resiliência - e se reconstituir.

[...] Só de não medicar uma criança, eu acho um avanço! (risos). É possível que alguém dissesse que precisasse de um antidepressivo para uma, ou precisasse de uma medicação específica para a enurese para a outra, mas, efetivamente, o reconhecimento desses aspectos pode ser fundamental.

3. Interpelar e reclamar - esta modalidade de cuidado é extremamente importante, sem a qual nenhum ser humano ascende à vida e à humanidade. Trata-se de uma forma de cuidado bastante ativa em que o outro que interpela e reclama funciona como um agente do confronto e do limite colocando o sujeito em contato com fatos significativos da existência como a morte, a finitude, a alteridade e a lei. Chamar à vida, chamar às falas e chamar à ordem são tão necessárias aos processos de constituição psíquica quanto as funções de acolher e reconhecer.

S6. [...] Até aquele momento eu não havia sentido o gosto da desgraça da infância - brasileira e principalmente da periferia - que eles já começavam a anunciar. Então, eles contavam casos de abandono, violência, adoecimentos incabíveis, maus tratos, e tudo isso eclodia nas multiplicações. Eu me lembro que um dia... eu... eu... eu dei um grito, um grito no sentido de um berro mesmo. Foi um momento em que eu, olhando para todo aquele grupo, que era um grupo imenso, e extremamente impressionado com o que eu mesmo haveria de dizer, porque eu mesmo ainda não havia ouvido, eu pergunto: _Mas, então, quem vai dizer às crianças que viver vale a pena?' $E$ ainda tem todo esse silêncio, porque, em situações muito hostis à vida, é muito difícil dizer a alguém que vale a pena a vida. Mas me lembro desse ponto de interrogação que eu carrego até hoje, vou carregar talvez pra sempre. 
Como modalidade de 'presença em reserva', Figueiredo (2009) fala da capacidade do cuidador de renunciar à sua própria onipotência, aceitando sua dependência. Para cuidar do outro, também é preciso cuidar de si, deixando-se cuidar: a mutualidade no cuidado é um dos princípios éticos mais fundamentais. Assim, o cuidador pode ganhar muito ao descobrir que o outro - objeto dos seus cuidados também pode exercer funções cuidadoras e cuidá-lo de alguma forma.

Essa 'presença em reserva' também cria um espaço vital desobstruído, nãosaturado da presença do cuidador e seus fazeres.

No limite, o cuidador ficará mais livre daquelas modalidades de cuidados em que o excesso de implicação despotencializa, desqualifica e aprisiona os objetos do seu cuidado (bebês, alunos, pacientes etc.).

S6. [...] Lembro de um dos conteúdos das oficinas que é um dos capítulos iniciais da cartilha, valorizando a vida, que orientava o cuidador a valorizar qualquer aspecto vital que encontrasse pela frente, fosse uma planta, fosse um pequeno animal.

Se o tema da comunicação, inclusão e escuta dos usuários é reconhecidamente relevante na área da saúde, bem o demonstram nossos sujeitos de pesquisa.

Heckert (2007) reflete sobre os determinantes que produzem diferentes modos de escuta, especialmente a 'escuta surda' e a 'escuta-experimentação'. A autora explica que tomou emprestado de Luis Antonio dos Santos Baptista (UFF Universidade Federal Fluminense) o conceito de escuta surda e de Suely Rolnik (PUC-SP) o conceito de escuta-experimentação.

A escuta surda refere aquelas práticas que ouvem sem escutar, isto é, que em lugar de indagarem acerca das evidências que nos constituem enquanto sujeitos, terminam elas mesmas por nos conduzir. Produz-se assim "uma medicina das evidências, uma psicologia das evidências, uma enfermagem das evidências que, tendo seus procedimentos dirigidos por naturalizações, pouco consegue captar as 
singularidades que permeiam o humano, a variabilidade e imprevisibilidade que constitui o vivo" (Heckert, 2007:7).

Neste sentido, a escuta surda é um ato protocolar, uma técnica de coleta de evidências ou sinais. Seu efeito mais danoso é a tutela e a culpabilização dos sujeitos, uma vez que fala por em lugar de falar com eles. Transforma-se assim em uma escuta moral, pois é prescritiva e julgadora, mera repetição de formas instituídas.

_ "A escuta surda [...] não se lembra do rosto e dos només dos usuários e dos profissionais, da cor dos olhos e da pele, dos cheiros, das rugas e cicatrizes (marcas do vivido), dos saberes e histórias" (Heckert, 2007:8).

Abrir-se à alteridade implica em desviar-se do campo da escuta como técnica para mergulhar no plano da escuta como experimentação, isto é, como perturbação do instituído. Portanto, não se trata de ensinar a escutar, mas de entrar em contato, atiçar este plano do coletivo do qual todos nós emergimos, onde há saberesexperimentações e não saberes-formatos-definidos a serem aplicados.

Isto quer dizer que as práticas de cuidado e os modos de escuta a elas relacionados são engendrados num campo de relações de saber e de poder e precisam estar permanentemente em análise.

\subsubsection{Percepção de valores sociais e compreensão dos determinantes sociais do processo saúde-doença}

Esta categoria agrega percepções, idéias e reflexões dos sujeitos sobre os determinantes sociais do processo saúde-doença relacionados a aspectos afetivos, familiares e sociais, com especial ênfase na formação de redes e na defesa de direitos de cidadania.

Segundo Dowbor (2008), a literatura científica sobre determinantes sociais de saúde identifica um grupo de vinte e dois determinantes com forte correlação entre si. São eles: saneamento, inclusão social, transporte, segurança, modelos de atenção à saúde, habitação, alimentação, auto-estima, drogadicção, lazer, 
emprego, educação, paz, renda, stress, primeiros anos de vida, rede de suporte social, distribuição de renda, ambiente de trabalho, justiça social/eqüidade, recursos sustentáveis e ecossistema saudável.

O conceito de patrimônio da família, um dos conceitos centrais do Projeto Janelas, apóia-se em boa parte dos determinantes sociais indicados na referida literatura.

Os determinantes sociais da saúde foram oficialmente reconhecidos pela primeira vez em 1974, pelo governo do Canadá através de seu Ministro da Saúde Marc Lalonde que declarou ser a saúde resultado da inter-relação de aspectos biológicos, ambientais, estilos de vida e organização do sistema de saúde (Lalonde, 1974).

Aqui no Brasil, desde a época do Relatório Lalonde, estudiosos e militantes do Movimento da Reforma Sanitária ampliaram o conceito de saúde incluindo determinantes estruturais do processo saúde-doença, o que serviu de base para o surgimento do campo da Saúde Coletiva (Carvalho, 2007).

\begin{abstract}
- "É no campo da saúde coletiva que se trabalham as idéias herdadas da reforma sanitária, cabendo aos intelectuais e militantes desse campo a formulação de proposições que ajudem o SUS a se aproximar de seus princípios, num jogo complexo, em que existe uma tensão permanente entre saúde como direito do cidadão e saúde como mercadoria" (Feuerwerker, 2005).
\end{abstract}

Para alguns, a ampliação do conceito de saúde para além do biológico e da referência de ausência de doença é um importante avanço; para outros, esse avanço é insuficiente porque não considera suficientemente a relação saúde e ambiente, além de privilegiar os estilos de vida individuais como fatores promotores de qualidade de vida, o que, em última instância, termina por culpabilizar o indivíduo.

Portanto, este é um campo de análise onde divergências importantes precisam ser reconhecidas. 
Dowbor (2008) relacionou cinco diferentes definições de saúde e suas implicações para a determinação social da saúde, conforme apresentado no quadro abaixo.

Quadro III. Determinação social da saúde e conceitos de saúde segundo Dowbor

\begin{tabular}{|l|l|}
\hline \multicolumn{1}{|c|}{ Definição de Saúde } & Implicações para a Determinação Social da Saúde \\
\hline Ausência de doença & $\begin{array}{l}\text { Aspectos sociais como determinantes de morbidade e } \\
\text { mortalidade }\end{array}$ \\
\hline Produto Holístico & $\begin{array}{l}\text { Aspectos sociais como determinantes de qualidade de } \\
\text { vida (o que pode incluir morbidade e mortalidade) }\end{array}$ \\
\hline Recurso Holístico & $\begin{array}{l}\text { Aspectos sociais como determinantes do processo de } \\
\text { empoderamento dos indivíduos e comunidades }\end{array}$ \\
\hline $\begin{array}{l}\text { Produto Holístico e } \\
\text { Recurso para a vida }\end{array}$ & $\begin{array}{l}\text { Aspectos sociais como determinantes de qualidade de } \\
\text { vida e do processo de empoderamento dos indivíduos } \\
\text { e comunidades }\end{array}$ \\
\hline Direito Humano & $\begin{array}{l}\text { Aspectos sociais como determinantes da distribuição } \\
\text { da saúde, seja ela ausência de doença, produto } \\
\text { holístico e/ou recurso para a vida }\end{array}$ \\
\hline
\end{tabular}

Fonte: extraído de Dowbor (2008:39)

Os extratos de entrevistas apresentados a seguir estão mais fortemente ligados ao empoderamento comunitário (Carvalho e Gastaldo, 2008) e aos conceitos de saúde enquanto recurso holístico e direito humano (Dowbor, 2008).

S1. Então, prá mim foi muito importante, porque eu acho que eu pude amadurecer tudo isso, que já tava ali incomodando e eu não tinha permitido espaço para pensar sobre isso. Aí fez todo sentido porque muda toda a tua concepção frente as pessoas, frente as situações, frente ao que você observa no âmbito social, e aí, conseqüentemente, muda valores.

[...] Quando a gente adentrou as questões da violência - eu me lembro muito daquela música, do que a gente discutiu, foi muito forte - aí a gente vê a violência ir se construindo e começa a pensar com um pouco mais de profundidade, isso muda a forma de você entender como essa violência surge, isso faz com que, tudo 
bem, ali foi um momento, foi um dos capítulos da capacitação que a gente teve, mas te faz buscar mais elementos. E eu me recordo que comecei a me interessar pelo ECA [Estatuto da Criança e do Adolescente], que depois disso eu fazia voluntariado no CEDECA. [Centro de Defesa dos Direitos da Criança e do Adolescente]

[...] Não dá prá dizer que o social não está envolvido aí, que a questão políticosocial e econômica não está envolvida aí. É claro que você não vai fazer nenhum discurso sociológico, aquela coisa toda, mas vai fazer com que as pessoas percebam determinadas relações.

[...] Aí, você olha e todo mundo parece que se empondera de alguma coisa.

S2. Então, eu não quero só saber como é que come, eu quero saber como está na escola, é com este pensamento que a gente acaba descobrindo o trabalho infantil, os relatos que algumas mães trazem de como o filho está sendo tratado na escola

S5. Pelo protocolo, a gente tem esquematizado o que é importante fazer pra que essa criança tenha saúde, mas não vai mais a fundo no por que está acontecendo, quais são os problemas reais. Então, a gente tem que trabalhar na parte dos determinantes.

[...] Tem algo muito maior por trás, que a gente pode estar levantando, e aí entram os determinantes, isto é, a rede, quem vai poder ajudar...

S6. Olhar uma criança sem conseguir estabelecer conexões entre os seus cuidadores mais imediatos e a sua rede social é deixá-la tão sozinha quanto não enxergá-la, quanto ela não ser vista.

[...] Descobrimos muitas crianças expostas às drogas, tanto nos bares quanto dentro de casa. Essa abordagem levava o nosso alerta em relação à saúde da criança; também fazia com que nós interagíssemos com os pais, numa tentativa de diálogo sobre os riscos que isso traria para a criança.

[...] E nós trocávamos informações que variavam desde o peso, a estatura, até se a mãe falta muito à consulta ou não, passando pelo contexto familiar e as necessidades médicas propriamente ditas.

[...] Sim, desnutrição. E a mãe as abandonava em casa, costumava sair, se eu não me engano, para a região central de São Paulo, para o consumo de drogas. E eu me lembro que uma das vizinhas chegou no nosso grupo dizendo: _Olha, eu não agüento mais ver essas crianças desse jeito, e eu trouxe as crianças'. Naquele momento eu senti que o nosso papel era apoiar a atitude dela e fazer nossa a indignação dela. Como equipe, nós conseguimos fazer isso porque começamos imediatamente a ver quais recursos seriam possíveis para essa situação. 


\subsubsection{Práticas emancipatórias $\mathrm{x}$ práticas regulatórias}

Os conteúdos de entrevistas reunidos nesta categoria representam uma contradição dialética de modelos, isto é, 'encaixam-se' no 'velho' paradigma biomédico e no paradigma crítico emergente. Trata-se de relatos críticos em sua maioria e reflexões de tendência contrária.

No âmbito das práticas calcadas no 'velho' paradigma, isto é, no paradigma biomédico, os principais conteúdos encontrados referem-se a práticas sanitárias de controle e regulação do comportamento da população, negação e desvalorização do saber popular, supervalorização do conhecimento técnico-científico e transmissão vertical sem a participação efetiva da população.

No âmbito das práticas inspiradas no paradigma emergente, isto é, no paradigma crítico-participativo aplicado ao campo da saúde, os conteúdos enfatizam os processos participativos, as interações afetivas, a amorosidade, a suspensão de julgamentos morais, a ampliação do olhar clínico, uma visão integral do ser humano e o reconhecimento da criança como sujeito de direitos.

A dinâmica do paradigma biomédico, ao conter o gérmen da sua superação, expressa-se nas contradições dialéticas entre culpabilização da vítima e empoderamento psicológico ${ }^{13}$, cooptação da participação popular e empoderamento comunitário e entre educação bancária e educação como prática da liberdade ${ }^{14}$.

Qualquer concepção de algo como totalidade - seja esse algo uma sociedade, um indivíduo, um estado ou processo de saúde ou doença, uma percepção ou julgamento individual ou coletivo - denota um conhecimento totalizante da ordem sobre o caos. Boaventura de Sousa Santos (2005) entende que o conhecimento de tipo totalizante é funcionalista porque busca a ordem da regulação social e o conhecimento não totalizante é transformador porque busca a ordem da emancipação social.

\footnotetext{
${ }^{13}$ Empoderamento psicológico e empoderamento comunitário tal como exposto no artigo de Sergio Resende de Carvalho e Denise Gastaldo (2008).

${ }^{14}$ Empowerment education em Paulo Freire.
} 
Para Paulo Freire (2009), as concepções totalizantes de homem e de mundo estão na raiz dos processos de acomodação e ajustamento. A visão que o homem tem de si mesmo e do mundo não pode absolutizar-se, sob pena dele se sentir desgarrado, suspenso, desconectado no tempo e no espaço. Enfim, desumanizado.

"A integração resulta da capacidade de ajustar-se à realidade acrescida da de transformá-la a que se junta a de optar, cuja nota fundamental é a criticidade. Na medida em que o homem perde a capacidade de optar e vai sendo submetido a prescrições alheias que o minimizam e as suas decisões já não são suas, porque resultadas de comandos estranhos, já na se integra. Acomoda-se. Ajusta-se. O homem integrado é o homem Sujeito. A adaptação é assim um conceito passivo - a integração ou comunhão, ativo. Este aspecto passivo se revela no fato de que não seria o homem capaz de alterar a realidade, pelo contrário, altera-se a si para adaptar-se. A adaptação daria margem apenas a uma débil ação defensiva. Para defender-se, o máximo que faz é adaptar-se. Daí que os homens indóceis, com ânimo revolucionário, se chame de subversivos. De inadaptados". (Freire, 2009: nota 4, pg. 50)

Desse modo, a integração vai se aperfeiçoando com o desenvolvimento da criticidade da consciência. Fosse o homem apenas um ser de acomodação, a História e a Cultura não teriam sentido algum; faltar-Ihe-ia a marca da liberdade. Por isso que sempre que a liberdade é suprimida o homem transforma-se em ser de acomodação e ajustamento. Com a supressão da liberdade, a primeira capacidade humana que é sacrificada é a sua capacidade criadora.

Segundo Boaventura de Sousa Santos (2005), os dois pilares do paradigma da modernidade - regulação e emancipação - são constituídos por três princípios e três lógicas respectivamente. O pilar da regulação é constituído pelo princípio do Estado, que estabelece uma relação vertical com os cidadãos; pelo princípio do mercado, que estabelece uma relação horizontal individual e antagônica entre os parceiros; e o princípio da comunidade, que estabelece uma relação horizontal solidária entre os membros da comunidade e associações. De modo análogo, o pilar da emancipação é constituído por três lógicas de racionalidade: a racionalidade estético-expressiva das artes e da literatura, a racionalidade 
cognitivo-instrumental da ciência e da tecnologia e a racionalidade moral-prática da ética e do direito.

\begin{abstract}
"O paradigma da modernidade é um projeto ambicioso e revolucionário, mas é também um projeto com contradições internas. Por um lado, a envergadura das suas propostas abre um vasto horizonte à inovação social e cultural; por outro, a complexidade dos seus elementos constitutivos torna praticamente impossível evitar que o cumprimento das promessas seja nuns casos excessivo e noutros insuficiente. Tanto os excessos como os défices estão inscritos na matriz paradigmática" (Santos, 2005:50).
\end{abstract}

Neste início de século e milênio, estamos vivendo uma importante crise paradigmática que nos coloca diante da desordem tanto da regulação quanto da emancipação. $\mathrm{Na}$ atualidade, as sociedades humanas são ao mesmo tempo autoritárias e libertárias.

Boaventura nos ensina que um paradigma emergente só pode ser conhecido por via especulativa, especulação essa que vai se fundamentando nos sinais da crise do paradigma atual. Portanto, qualquer tentativa de desenhar o futuro será sempre uma tentativa de cunho pessoal e imaginativo, uma imaginação sociológica no caso do autor, sociólogo que é.

"Eu falarei do paradigma de um conhecimento
prudente para uma vida decente. Com esta designação,
quero significar que a natureza da revolução científica que
atravessamos é estruturalmente diferente da que ocorreu no
século XVI. Sendo uma revolução científica que ocorre numa
sociedade ela própria revolucionada pela ciência, o
paradigma a emergir dela não pode ser apenas um
paradigma científico (o paradigma de um conhecimento
prudente), tem de ser também um paradigma social (o
paradigma de uma vida decente)" (Santos, 2005:74).

A análise do paradigma da modernidade de Boaventura de Sousa Santos, com seus pilares de sustentação e respectivos princípios e lógicas, é uma bússola capaz de orientar a identificação de uma ampla gama de diferentes cenários e práticas, alguns mais determinados pela regulação, outros mais pela emancipação social. Dos princípios que regem o pilar da regulação, o princípio da comunidade é 
o que ficou mais aberto, inacabado; e das lógicas que regem o pilar da emancipação, seria a racionalidade estético-expressiva a representação mais inacabada. Boaventura indica essas duas representações inacabadas como verdadeiras brechas para a construção de uma transição paradigmática mais determinada pelos princípios e lógicas da emancipação social.

\begin{abstract}
"[...] o princípio da comunidade foi, nos últimos duzentos anos, o mais negligenciado. E tanto assim foi que acabou por ser quase totalmente absorvido pelos princípios do Estado e do mercado. Mas, também por isso, é o princípio menos obstruído por determinações e, portanto, o mais bem colocado para instaurar uma dialética positiva com o pilar da emancipação. [...] Relativamente ao pilar da emancipação, apesar de, como já afirmei, tanto a racionalidade moralprática como a estético-expressiva terem sido invadidas pela racionalidade cognitivo-instrumental e performativo-utilitária da ciência, a racionalidade estético-expressiva, em minha opinião, resistiu melhor à cooptação total" (Santos, 2005:75).
\end{abstract}

O Quadro IV organiza de forma didática as práticas educativas dos sujeitos de pesquisa correlacionando-as a conceitos, abordagens e paradigmas, com ênfase analítica nos princípios e lógicas do paradigma da modernidade. 
Quadro IV. APRENDER A FAZER: correlacionando práticas, conceitos, abordagens e paradigmas

\begin{tabular}{|c|c|c|c|}
\hline \multirow{4}{*}{$\begin{array}{l}\text { I. Paradigma } \\
\text { biomédico do } \\
\text { campo da saúde }\end{array}$} & \multirow[t]{4}{*}{$\begin{array}{l}\text { 1. Estado (relação vertical com os } \\
\text { cidadãos) }\end{array}$} & $\begin{array}{l}\text { 1.1. Abordagem sanitária de controle e } \\
\text { regulação do comportamento da população }\end{array}$ & $\begin{array}{l}\text { S3. Infelizmente a gente é mais voltada para as doenças } \\
\text { mesmo, e tem as doenças sazonais, é dengue, é } \\
\text { leptospirose, é gripe -e a gente trabalha em cima disso. }\end{array}$ \\
\hline & & $\begin{array}{l}\text { 1.2. Abordagem de } \\
\text { responsabilização/culpabilização da vítima }\end{array}$ & $\begin{array}{l}\text { S4. Aí nós falamos assim: 'Quem é o problema? É ela [a } \\
\text { mãe] quem tem que mudarl'. A psicóloga diz que quem tem } \\
\text { que mudar é ela, é o adulto, não adianta querer que a } \\
\text { criança seja de uma maneira se não trabalhar o adulto. }\end{array}$ \\
\hline & & $\begin{array}{l}\text { 1.3. Abordagem não participativa - } \\
\text { transmissão vertical do conhecimento }\end{array}$ & $\begin{array}{l}\text { S2. Normalmente, elas [as gestantes] têm uma idéia de que } \\
\text { você vai lá ouvir uma palestra. (enquanto crítica ao modelo } \\
\text { biomédico) } \\
\text { S5. É uma troca, eu não vejo mais como uma imposição, eu } \\
\text { como técnica falando como tem que ser feito. (enquanto } \\
\text { crítica ao modelo biomédico) }\end{array}$ \\
\hline & & $\begin{array}{l}\text { 1.4. Saber oficial em detrimento do saber } \\
\text { popular }\end{array}$ & $\begin{array}{l}\text { S3. É, e a gente trabalha com uma população carente, eles } \\
\text { são carentes de tudo. São carentes de informação, de } \\
\text { educação, de espírito, de tudo que você possa imaginar. } \\
\text { S3. Porque a gente comete erros, por mais que a mãe não } \\
\text { queira, eu falo pra mãe, não se penalize, você não sabia, } \\
\text { porque a gente peca por ignorância. }\end{array}$ \\
\hline
\end{tabular}




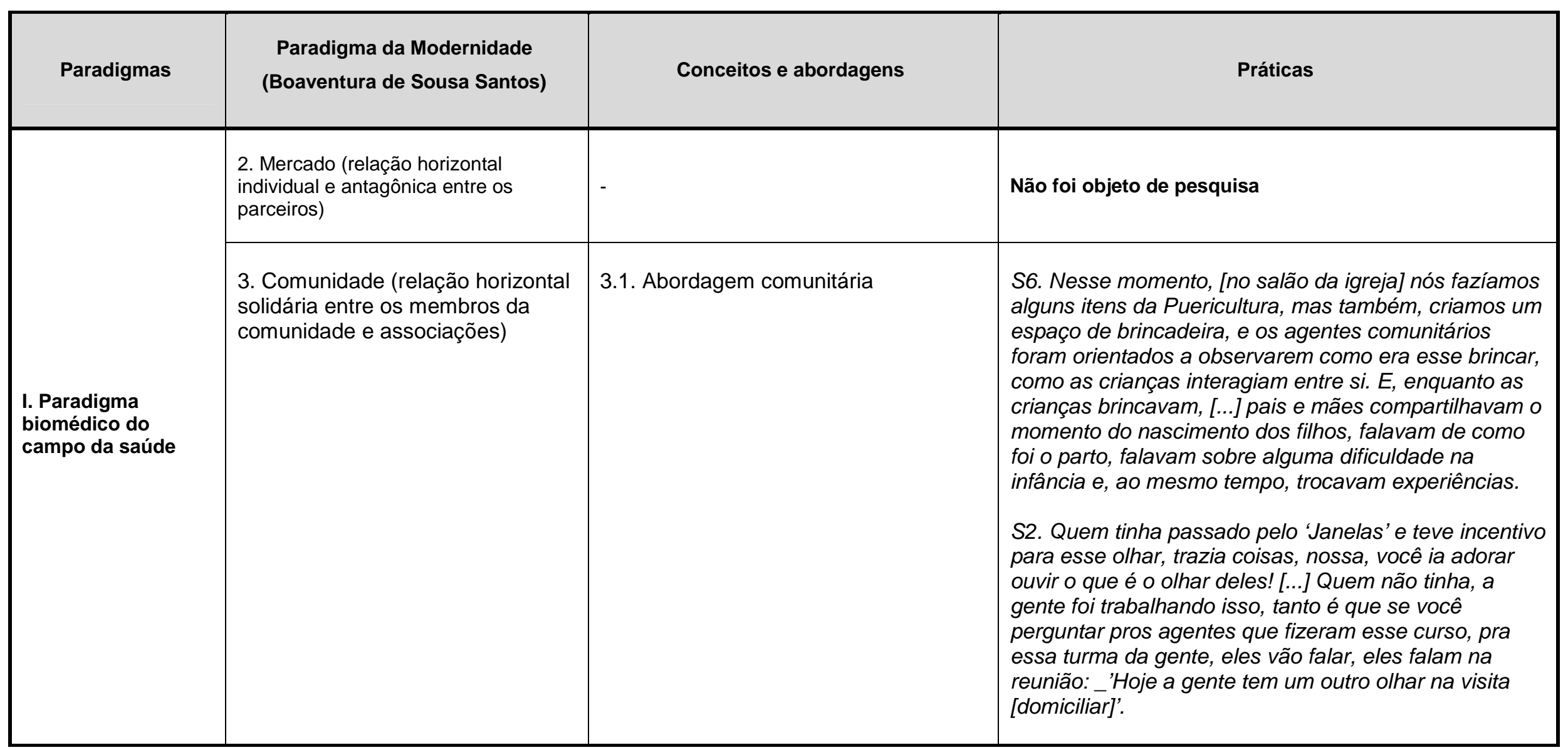




\begin{tabular}{|c|c|c|c|}
\hline \multirow[t]{2}{*}{$\begin{array}{l}\text { II. Paradigma } \\
\text { crítico- } \\
\text { participativo } \\
\text { aplicado ao } \\
\text { campo da saúde }\end{array}$} & $\begin{array}{l}\text { 1. Racionalidade cognitivo- } \\
\text { instrumental (ciência e tecnologia) }\end{array}$ & $\begin{array}{l}\text { 1.1. Conhecimento técnico-científico } \\
\text { compartilhado com a população }\end{array}$ & $\begin{array}{l}\text { S2. Eu usei muito todo esse embasamento, todo esse } \\
\text { alimento que o 'Janelas' me trouxe, eu usei muito pra } \\
\text { discutir com eles [os ACS] várias questões da visita, do } \\
\text { olhar, das relações, o trabalho do apoio... Eu acho que } \\
\text { ele faz parte da minha vida, realmente. } \\
\text { S2. A gente também faz toda essa questão do olhar } \\
\text { biológico - nos meus grupos a gente tem isso muito } \\
\text { forte - e sempre procura estar focando também a } \\
\text { questão das relações, do afeto. (grupos de gestantes) } \\
\text { S5. Eles [os ACS] falavam assim: . 'Era muito legal ter } \\
\text { o programa das janelas porque a gente tinha um tema } \\
\text { pra falar com aquelas famílias e todo mundo falava } \\
\text { aquele mesmo tema. Então, a gente não ia só } \\
\text { perguntar como é que está a vacina, se está em } \\
\text { ordem, e tudo o mais, mas podia falar dos agravos, } \\
\text { dos riscos, ou [de] como a criança aprende. }\end{array}$ \\
\hline & $\begin{array}{l}\text { 2. Racionalidade moral-prática } \\
\text { (ética e direito) }\end{array}$ & 2.1. Escuta e cuidado & $\begin{array}{l}\text { S2. Nós não estamos condenando o fato delas [as } \\
\text { gestantes] não estarem querendo [o bebê], mas sim } \\
\text { apoiando, aceitando, recebendo aquilo, entendendo o } \\
\text { momento delas. } \\
\text { S6. Olha, os aspectos psicológicos, emocionais, } \\
\text { sociais, culturais, eles estão presentes no processo de } \\
\text { saúde e doença. Porém, reconhecê-los, às vezes } \\
\text { chega a ser terapêutico. }\end{array}$ \\
\hline
\end{tabular}




\begin{tabular}{|l|l|l|l|}
\hline \multicolumn{1}{|c|}{ Paradigmas } & \multicolumn{1}{|c|}{$\begin{array}{c}\text { Paradigma da Modernidade } \\
\text { (Boaventura de Sousa Santos) }\end{array}$} & Conceitos e abordagens & \multicolumn{1}{c|}{ Práticas } \\
\hline & $\begin{array}{l}\text { 3. Racionalidade estético- } \\
\text { expressiva (artes e literatura) }\end{array}$ & $\begin{array}{l}\text { 3.1. Empoderamento dos profissionais } \\
\text { de saúde e da população }\end{array}$ & $\begin{array}{l}\text { S4. Era uma fita de vídeo que nós assistimos. Tinha } \\
\text { um cara que [se tornou um] adulto, uma pessoa super } \\
\text { revoltada, e aparece ele jogando pedras no lago; e a } \\
\text { cada pedra que ele jogava no lago era um problema } \\
\text { que ele tava tirando dele! [...] Eu queria trabalhar na } \\
\text { unidade; se tiver, eu ainda vou usar, porque eu achei } \\
\text { demais! Ela é muito tocante, né? [...] Eu queria levar } \\
\text { pra população. }\end{array}$ \\
$\begin{array}{l}\text { II. Paradigma } \\
\text { crítico- } \\
\text { participativo } \\
\text { aplicado ao } \\
\text { campo da saúde }\end{array}$ & $\begin{array}{l}\text { S2. [ampliado pela dimensão] do vínculo, do afetivo, do } \\
\text { respeito à cultura de cada pessoa, de que é diferente } \\
\text { você estar aqui pra apoiar o desenvolvimento das } \\
\text { pessoas, apoiar o empoderamento das pessoas [...] } \\
\text { você pode apoiar através das suas orientações, apoiar } \\
\text { de várias formas, mas que nós não estamos aqui pra } \\
\text { criticar nem pra julgar. Então, isso faz a diferença do } \\
\text { olhar. } \\
\text { S2. [...] a gente vai trabalhando muito a questão do } \\
\text { vínculo, do afeto com a criança como alimento } \\
\text { fundamental, como proteção da saúde mental da } \\
\text { criança. Em todos os encontros a gente permeia esta } \\
\text { questão do vinculo, do afeto. }\end{array}$ \\
\hline
\end{tabular}




\begin{tabular}{|l|l|l|l|}
\hline \multicolumn{1}{|c|}{ Paradigmas } & $\begin{array}{c}\text { Paradigma da Modernidade } \\
\text { (Boaventura de Sousa Santos) }\end{array}$ & Conceitos e abordagens & \multicolumn{1}{c|}{ Práticas } \\
\hline & $\begin{array}{l}\text { 3. Racionalidade estético- } \\
\text { expressiva (artes e literatura) }\end{array}$ & $\begin{array}{l}\text { 3.2. Abordagem participativa } \\
\text { II. Paradigma crítico- } \\
\text { participativo aplicado } \\
\text { ao campo da saúde }\end{array}$ & $\begin{array}{l}\text { S5. Antigamente era [pra ficar] lá fora; agora não, } \\
\text { entram todos juntos - eu já tenho os meus lápis } \\
\text { de cera, enquanto isso eles brincam, conversam - } \\
\text { e eu vou vendo a integração dessa família. Então, } \\
\text { não é mais aquele olhar focado nos problemas, } \\
\text { nas doenças, mas amplia para a saúde, para } \\
\text { como é que eles estão interagindo entre eles. } \\
\text { S2. Todas as nossas praticas educativas aqui são } \\
\text { participativas, [...] de uma forma bem } \\
\text { descontraída, buscando a proximidade. } \\
\text { S3. Tem uma auxiliar de enfermagem aqui que é } \\
\text { maravilhada pelo 'Janelas', que fala dele até hoje. } \\
\text { São coisas que vieram, que a gente passou, e eu } \\
\text { acho que a gente passou de uma forma boa, } \\
\text { porque senão não ficaria. Não sei qual a } \\
\text { experiência que você tem de outros lugares, } \\
\text { porque aqui foi muito legal, a gente vivenciou uma } \\
\text { época de aprendizado, muito produtiva. }\end{array}$ \\
\hline
\end{tabular}




\begin{tabular}{|c|c|c|c|}
\hline Paradigmas & $\begin{array}{l}\text { Paradigma da Modernidade } \\
\text { (Boaventura de Sousa Santos) }\end{array}$ & Conceitos e abordagens & Práticas \\
\hline $\begin{array}{l}\text { II. Paradigma crítico- } \\
\text { participativo aplicado } \\
\text { ao campo da saúde }\end{array}$ & $\begin{array}{l}\text { 3. Racionalidade estético- } \\
\text { expressiva (artes e literatura) }\end{array}$ & 3.3. Integralidade do cuidado & $\begin{array}{l}\text { S3. No momento das consultas [...] você } \\
\text { consegue visualizar se a criança é pouco } \\
\text { estimulada, se a criança não responde - depois } \\
\text { que ela passa quinze, vinte minutos com você, } \\
\text { com você estimulando e aí ela passa a responder, } \\
\text { então você observa que essa criança não é tão } \\
\text { estimulada quanto deveria. } \\
\text { S6. Depois do 'Janelas', nunca mais uma criança } \\
\text { me escapou do campo de visão. Então, você } \\
\text { amplia a sua visão de mundo para incluir a } \\
\text { infância, em minha opinião. } \\
\text { S6. É uma experiência integrativa, porque você } \\
\text { está olhando para a criança, olhando para si } \\
\text { mesmo e olhando para o seu entorno - o seu } \\
\text { próprio - no seu próprio processo de formação, } \\
\text { para depois, ao se localizar, poder também olhar } \\
\text { para o outro e para o entorno desse outro. } \\
\text { S6. E nós trocávamos informações que variavam } \\
\text { desde o peso, a estatura, até se a mãe falta muito } \\
\text { à consulta ou não, passando pelo contexto } \\
\text { familiar e as necessidades médicas propriamente } \\
\text { ditas. }\end{array}$ \\
\hline
\end{tabular}




\title{
3.2.2.4 Práticas intersetoriais
}

Esta categoria nasceu dos discursos dos sujeitos de pesquisa que apontaram seus saberes e fazeres em saúde numa perspectiva intersetorial.

No cuidar em saúde há uma potencialidade reconciliadora entre as práticas assistenciais e a vida, uma vez que um diálogo aberto e produtivo entre a tecnociência e um projeto de vida solidária e livre é possível (Ayres, 2004). O autor chama a atenção para os diversos desafios que se colocam nessa reconstrução das práticas do cuidado em saúde, sendo um deles o fortalecimento da atuação intersetorial.

\begin{abstract}
"É preciso superar a conformação individualista, rumo a esferas também coletivas, institucionais e estruturais de intervenção e enriquecer a racionalidade biomédica com construtos de outras ciências e outros saberes. Todos esses nortes dependem de que saiam do jargão sanitário e passem a fazer parte de efetivos rearranjos tecnológicos as surradas bandeiras da interdisciplinaridade e intersetorialidade - as quais nunca será demais endossar. [...] Os Programas de Saúde da Família (PSF) dão nova base para articulações intersetoriais e promovem a entrada de novos cenários, sujeitos e linguagens na cena da assistência; a sensibilidade para os aspectos sócio-culturais do processo saúde-doença ganha novo ímpeto com a crescente ênfase dada à promoção da saúde; quadros como o da vulnerabilidade resgatam os aspectos contextuais e institucionais como esfera de diagnóstico e intervenção em saúde, chamando à interação entre diferentes disciplinas $e$ áreas do conhecimento; a vigilância da saúde incorpora novos objetos e tecnologias e, especialmente, propicia um intenso protagonismo comunitário na definição de finalidades e meios do trabalho sanitário" (Ayres, 2004:89).
\end{abstract}

No âmbito municipal, a atuação intersetorial se processa na ação comunitária no território, na articulação na SMS e na articulação das políticas municipais. Giovanella et al (2009) apontam esforços significativos das equipes de SF no sentido de desenvolverem práticas intersetoriais, ainda que do ponto de vista quantitativo sejam bastante insuficientes. 
- "Ainda que se reconheça que os esforços das práticas intersetoriais das ESF sofrem limitações, [...] os resultados indicam que esta não é uma prática disseminada. Menos de um terço à metade dos profissionais desenvolvem ações voltadas para solução de problemas da comunidade. Os resultados pífios apontados pelas famílias para ação comunitária das ESF são coerentes com resultados de outros estudos que mostram baixo escore para a "orientação comunitária" por usuários da SF, ainda que melhores do que àqueles das UBS tradicionais" (Giovanella, 2009).

Felizmente, essa capacidade de articular e integrar saberes e ações das diferentes políticas públicas vem sendo cada vez mais reconhecida como fundamental, inclusive pelos sujeitos desta pesquisa.

S1. Eu acho que essa capacitação foi uma cutucada, eu sempre falava que ia fazer uma faculdade de Serviço Social. Hoje eu vejo que não preciso fazer faculdade de Serviço Social. Depois que eu entrei na Assistência, eu não preciso.

[...] Quando eu me lembro de toda aquela experiência e da própria multiplicação que a gente fez com as agentes comunitárias e de tudo o que a gente conseguiu passar para elas, de vê-las amadurecendo e tal, então, eu tenho plena confiança em buscar o PSF como referência para subsidiar o nosso trabalho. A gente está recorrentemente buscando ações articuladas com o PSF.

[...] Buscar a Educação, buscar a Saúde, porque as demandas vêm de todos os lados, né? Então, eu vivo me deparando, eu chego ao serviço para a Supervisão, e aí a gente tem as questões da Saúde travando alguns encaminhamentos dos serviços...

S2. Nós recebemos até as fichas das escolas. Quais são as crianças? Quando você pega a ficha das crianças que eles mandaram: _Ah, essa criança é filho de fulana de tal, uma pessoa que faz acompanhamento de saúde mental com a gente; tem uma questão familiar desse rapaz que tem todo um processo de saúde mental ligado a uma mãe que o domina, etc.'. Você começa a entender o que está acontecendo com essa criança lá na escola, e a gente já queria mesmo ver essa criança mais de perto.

S3. Hoje em dia eu estou indo numa escola para fazer justamente essa prática de saúde e educação, porque a gente precisa unir [as duas]. Quando eu passo a informação relacionada à saúde ali dentro, eles aprendem muito mais; e quando é o professor, eles aprendem muito mais ainda.

S5. [...] porque são tantos problemas que aí você começa a contatar a assistente social, o conselho tutelar, outros aspectos que podem estar ajudando a fortificar 
essa família, pra que essa criança possa viver com um pouco mais de equilíbrio e ter um futuro melhor.

\subsection{3 'Aprender a conviver' e 'Aprender a ser': percepção de impacto das práticas educativas desenvolvidas com as famílias e comunidades}

Analisamos anteriormente a percepção de impacto dos sujeitos de pesquisa em relação a si próprios (subseção 3.2.1.2) à luz da categoria analítica empoderamento psicológico, uma vez que as mudanças relatadas por eles situamse neste âmbito. Em relação à análise das percepções dos sujeitos sobre valores e determinantes sociais (subseção 3.2.2.2) foi possível identificar algum tipo de visão crítico-social e de politização das ações por eles desenvolvidas e relacioná-las ao conceito de empoderamento comunitário.

Agora, trata-se de focalizar os efeitos do trabalho com as famílias e as comunidades.

Em relação às famílias, os relatos referem maior sensibilidade dos cuidadores em relação à importância da vinculação amorosa com a criança, antes mesmo dela nascer; aumento da disposição das mães em conversar mais com seus filhos, cantar e contar histórias para eles; maior envolvimento da figura do pai ou avô no cotidiano e na educação da criança; e aumento da participação do pai nos grupos educativos e nas consultas de pré-natal.

No âmbito da comunidade, quando as ações educativas eram articuladas em torno de um determinado tema da cartilha e desenvolvidas durante o mês inteiro nos diferentes espaços de atendimento - consultas, grupos, visitas domiciliares e reuniões comunitárias - as famílias demonstravam maior interesse e disposição em disseminar o assunto e orientar outras famílias da comunidade. Neste sentido, poderíamos chamá-las de 'famílias educadoras'. 
Estes resultados com a população são significativos enquanto processos de empoderamento através do 'aprender a conviver', além de orientarem-se no sentido da autonomia através do 'aprender a ser'.

A palavra autonomia, de origem grega, significa autogoverno, governar-se a si próprio (autos=próprio; nomos=regra ou governo).

É possível focalizar o debate moderno no âmbito da educação a partir do tema da autonomia enquanto um processo dialógico que envolve a capacidade do educando de buscar respostas às suas próprias perguntas de maneira livre e autônoma. Por outro lado, no campo da educação em saúde, a meta da promoção da autonomia individual é controversa e muito difícil de ser alcançada. Segundo Oliveira (2005), quando se trata de uma 'educação em saúde radical', claramente alinhada com as pedagogias críticas e emancipatórias, a adoção do princípio da autonomia implicaria na aceitação incondicional por parte dos profissionais de saúde das escolhas dos indivíduos, inclusive daquelas escolhas não saudáveis.

\begin{abstract}
"Apesar de o modelo radical ser teoricamente congruente com os propósitos da promoção da saúde, seu enfoque na promoção da autonomia através da educação não está isento de críticas. Essas têm tornado visível as contradições da promoção da saúde, evidenciadas na ênfase que se tem dado às intervenções comportamentais e no descaso para com as estruturais" (Oliveira, 2005:428).
\end{abstract}

Como promover ao mesmo tempo liberdade e saúde? É possível respeitar as escolhas dos indivíduos mesmo que elas afetem negativamente sua saúde? Como fazer promoção da saúde respeitando a liberdade e a autonomia da população?

Em Paulo Freire (2005 e 2009), o conceito de autonomia tem um sentido muito amplo na medida em que cabe à educação formar o homem consciente, crítico e capaz de transformar as estruturas opressoras e alienantes da sociedade em que vive - a autonomia inspirando a práxis que leva à libertação.

O Relatório Delors (1998), no pilar 'aprender a ser', enfatiza o papel essencial da Educação do século XXI no sentido de conferir aos seres humanos a liberdade de pensamento, discernimento, sentimentos e imaginação de que necessitam para 
desenvolver os seus talentos e permanecerem, tanto quanto possível, donos do seu próprio destino, isto é, autônomos. Ressalta também a grande importância da imaginação e da criatividade enquanto manifestações da liberdade humana que devem ser protegidas da ameaça da padronização dos comportamentos individuais.

\begin{abstract}
"Todo o ser humano deve ser preparado, especialmente graças à educação que recebe na juventude, para elaborar pensamentos autônomos e críticos e para formular os seus próprios juízos de valor, de modo a poder decidir, por si mesmo, como agir nas diferentes circunstâncias da vida" (Relatório Delors, 1998:99).
\end{abstract}

Segundo Donato (2000), o momento atual no campo da Educação é de resgate dos aspectos positivos das teorias aplicadas ao cotidiano escolar (as teorias nãocríticas) para colocá-las a serviço da transformação social (teorias críticas).

\begin{abstract}
"Assim, resgata-se da Pedagogia Tradicional a importância da dimensão do saber; da Escola Nova, a dimensão do saber ser, e da Pedagogia Tecnicista, a dimensão do saber fazer" (Donato, 2000:25, grifo do autor).
\end{abstract}

O conceito de autonomia em Paulo Freire se forja nas qualidades de educadores e educadoras progressistas que ele propõe em sua 'Quarta Carta' (2007b). São qualidades que vão se gerando na prática, pois ninguém nasce com elas, e todas elas muito necessárias à prática progressista:

- a humildade, que significa ouvir com atenção, saber dialogar: uma espécie de 'segurança insegura, a certeza incerta e não a certeza demasiado certa de si mesma'. (Freire, 2007b: 56);

- a amorosidade, mais próxima do 'amor armado', um amor de quem se afirma no direito e no dever de lutar, denunciar;

- a coragem de lutar (ao lado da coragem de amar), que implica na superação do medo através do seu reconhecimento. Não se trata de negar nem de abandonar-se ao medo, pois 'é no exercício desse controle que minha coragem necessária vai sendo partejada'. (Freire, 2007b: 58); 
- a tolerância, que permite a convivência com o diferente sem ser conivente com o intolerável, nem camuflar o agressor; tolerância também significa reconhecimento de limites;

- a decisão, que envolve uma ruptura que possibilita uma escolha;

- a segurança, aquela que, 'por sua vez, demanda competência científica, clareza política e integridade ética’. (Freire, 2007b: 61);

- a tensão entre paciência e impaciência, porque 'A virtude não está, pois, em nenhuma delas sem a outra, mas em viver a permanente tensão entre elas. Viver e atuar impacientemente paciente, sem jamais se dar a uma ou a outra, isoladamente'. (Freire, 2007b: 62);

- a parcimônia verbal, que é um corolário da tensão entre paciência e impaciência, pois 'Ambos estes discursos, o muito controlado como o em nada disciplinado, contribuem para a preservação do status quo. O primeiro por estar demasiado aquém da realidade; o segundo, por ir mais além do limite suportável'. (Freire, 2007b: 62);

- a alegria de viver, que costura a humildade, a amorosidade, a coragem, a tolerância, a competência, a capacidade de decidir, a segurança, a eticidade, a justiça, a tensão entre paciência e impaciência e a parcimônia verbal, criando a possibilidade de uma aventura educativa que não teme o risco, que recusa a apatia e o imobilismo.

Neste cenário dialético deu-se o processo de identificação dos conteúdos empíricos relacionados aos pilares 'aprender a conviver' (empoderar-se) e 'aprender a ser' (com liberdade e autonomia), atravessados que são pelo crivo desta contradição, ela própria constitutiva do campo da promoção da saúde.

S1. Aí um pai levanta a mão e:_Ah, eu queria agradecer muito a vocês, agradecer muito a Prefeitura por essa ajuda que está dando pra gente. Aí eu pedi para intervir e falei:_Olha, isso não é uma ajuda, isso é um direito seu, o senhor falou há pouco que não tem dinheiro para pagar curso para os seus filhos, que o senhor não tem dinheiro para pagar uma faculdade, mas o senhor está pagando os impostos! Aí, você olha e todo mundo parece que se empondera de alguma coisa. Esse pai, assim, foi como se... você vê mudança na postura, no olhar, sabe aquela coisa, aquele lugar de se sentir reconhecido, ele não tá ali pedindo um favor, ele não está recebendo um favor. Isso é muito rico, eu acho que isso é um salto. 
S2. E quando você vai fazer a visita do recém nascido, que é a primeira consulta, aí é muito bom, porque as que vêm no grupo, as que fizeram o pré-natal [...] no posto de saúde e que participaram do grupo têm uma outra relação com o bebê, tem uma outra relação com as dificuldades dos primeiros dias do bebê - porque a gente sabe que tem sim, que é muito difícil os primeiros meses do bebê, a chegada desse bebê em casa, elas ainda estão desgastadas com tantas coisas, o parto, etc., mas elas lidam de uma outra forma com isso.

[...] Fica muito clara a contribuição que o grupo traz. As ansiedades, as dificuldades de lidar com esse momento que exige tanto da mãe, os próprios cuidados práticos com o bebê, com o umbigo, com a amamentação. Normalmente a amamentação já está correndo risco, porque a pega está errada, porque a família já tá lá com a lata do NAN, e ela não está preparada, não teve esse apoio, não teve essa reflexão com relação à amamentação.

[...] Sim, criança mais bem cuidada, filho mais bem cuidado. Dessas que participam do grupo, poucas, raras têm problema com a mama. Aquela que não amamenta, não amamenta porque é uma escolha dela, não adianta, você não vai sensibilizar $100 \%$. Mas a gente está vendo que essas que vêm no grupo nós estamos conseguindo sensibilizar e ajudar a fortalecer pra esse ato de amamentação.

S5. [...] a gente via que os agentes de saúde falavam de um determinado tema naquele mês com algumas famílias e, de repente, a comunidade toda tava falando daquele tema! Uma família tava chamando a atenção de outra família, assim: _'Olha, os seus vidrinhos de alvejante, de cândida, estão aqui embaixo e a tua criança pode, sem querer, tomar!' [...] Então, de certo modo até a população começou a se educar.

[...] Eu observei, nos relatos das agentes de saúde, das mães, de todos, que as mães procuravam conversar mais com seus filhos, e isso graças [ao fato de] a gente começar a conversar [sobre] o que é uma criança, o que quer dizer quando uma criança de três anos fala um não, que esse 'não' não é porque ela está negando a mãe, muito pelo contrario, ela está querendo se afirmar como um ser já independente. Então, com isso começaram a acontecer muito menos discussões entre mãe e filho, começou a se ver que as famílias nem sempre são só mãe e filhinho - muitas vezes tinha o pai, e o que a gente mais queria era envolver a família toda - e os pais começaram a entender melhor seus filhos e a conversar mais com eles. Os avôs, que são muito presentes na vida das crianças, muitas vezes [porque] os pais saem pra trabalhar, começaram a entender melhor essas crianças. Começaram a entender, e a própria equipe de saúde, o quanto é importante a historinha, conversar, cantar, brincar. Que o brincar não era uma brincadeira de passatempo, mas era o jeito que a criança tem de trazer pra fora 0 seu mundinho, [de mostrar] como é que ela estava vivendo esse mundo. Então, eu acho que essa visão a gente não perde nunca mais. 
[...] Eu faço questão absoluta de trazer o companheiro da gestante, quer dizer, a pessoa que é o pai. Faço questão de conversar sobre se essa criança é homem ou mulher, menino ou menina, qual vai ser o seu nome, e já começar a chamar essa criança pelo nome.

[...] Porque a gente vê famílias que tem muita pobreza, muita dificuldade, mas tem esse calor humano, de formar, de receber um ser e dar chance pra essa criança desenvolver essa resiliência, com mais equilíbrio, e depois ser um adolescente que também consiga passar melhor por essas fases de drogas e de violência e tudo mais.

S6. Uma das coisas mais interessantes, mais dignas de nota nesse grupo de pais, foi a presença dos homens, a presença masculina, porque algumas mães trabalhavam fora e os pais traziam as crianças.

[...] Descobrimos muitas crianças expostas às drogas, tanto nos bares quanto dentro de casa. Essa abordagem levava o nosso alerta em relação à saúde da criança; também fazia com que nós interagíssemos com os pais, numa tentativa de diálogo sobre os riscos que isso traria para a criança. 


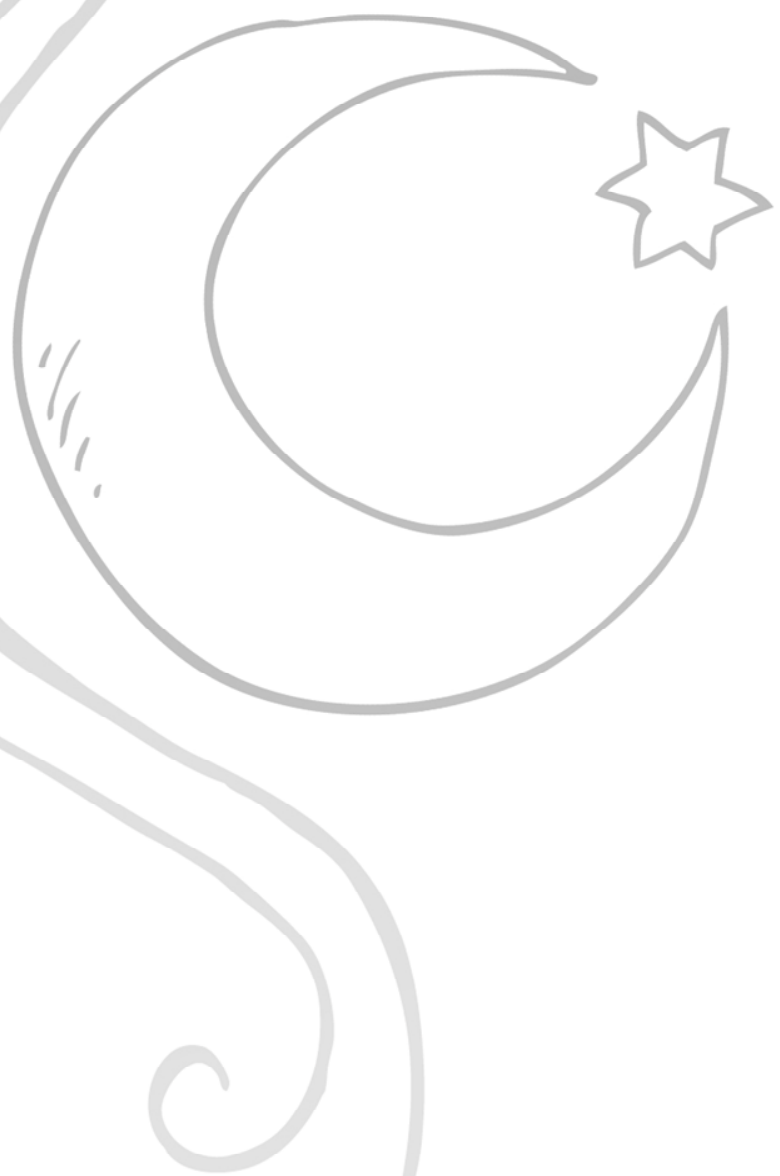

VIDA

Vida que me hiciste al día Hoy me siento noche Por eso te canto Toda, toda esa porfía Derramó ternura $Y$ hoy se me hace oscura $\mathrm{Y}$ yo sin querer De que fueras mía...

Al viento los sueños de la gran ciudad La luna me alumbra todo este pasar

Vida no me niegues nada

Porque en tus entrañas Arde la esperanza

De días, de días mejores

Que el trabajo valga

Que la gente sepa Lo que es aprender a sentirte intensa Como llama inmensa Como bien común.

Nelson Araya

Músico e compositor

CD Medicos Descalzos - marzo 2005

Santiago do Chile 


\section{CONSIDERAÇõES FINAIS}

O caminho metodológico escolhido permitiu acessar os temas de pesquisa que, por sua vez, foram muito bem desenvolvidos pelos sujeitos nela implicados. Estes conteúdos constam integralmente no Anexo $\mathrm{F}$, tendo sido tomados os devidos cuidados para a proteção da identidade dos entrevistados.

Os relatos dos sujeitos sobre a experiência de formação que receberam do Projeto Janelas e suas práticas enquanto formadores dos profissionais das equipes de saúde (a 'multiplicação') fluíram com muita vivacidade de memória e motivação. Entretanto, os conteúdos ligados à pesquisa das praticas educativas com famílias e grupos na comunidade - diretamente atendidos ou acompanhados através das ações dos agentes comunitários de saúde - fluíram menos e, portanto, exigiram maior esforço investigativo da pesquisadora.

Quanto à contribuição de outros cursos e capacitações para o fortalecimento das práticas de educação em saúde, foi quase unânime a constatação de sua inexistência, o que demonstra, no mínimo, descaso e falta de investimento da gestão pública e das instituições parceiras da Estratégia Saúde da Família da cidade de São Paulo na qualificação de seus profissionais.

Algumas características ou qualidades dos entrevistados - sua bagagem anterior chamaram a atenção e podem estar relacionadas ao seu grau de envolvimento e compromisso com a tarefa educativa em suas práticas cotidianas. Suas qualidades favoráveis referem-se a uma atitude de abertura para aprender, explorar novos campos do conhecimento e da experiência, estabelecer vínculos afetivos, além de uma visão ampliada e integral de ser humano associada à disposição para trabalhar de forma intersetorial. Por outro lado, ter ou não ter formação especializada na área de saúde da criança não é fator importante para o engajamento na proposta do Projeto Janelas.

No âmbito das práticas educativas propriamente ditas, os resultados encontrados são especialmente relevantes em um cenário de mudança de concepção teórica sem alteração significativa das práticas, preponderantemente de caráter prescritivo 
e normativo, que focalizam os comportamentos saudáveis individuais sem problematizar as raízes do processo saúde-doença e, conseqüentemente, contribuir para a transformação da realidade de diferentes grupos e classes sociais. No recorte específico das práticas educativas relacionadas à saúde da criança, o cenário não é diferente: restringe-se a avaliação ao desenvolvimento físico e motor, imunização e, no máximo, aleitamento materno, com prescrições aos familiares sobre o que devem e não devem fazer.

Portanto, a promoção da saúde da criança através do fortalecimento dos cuidados familiares para além da atenção ao corpo físico que inclui estimulação precoce, vinculação afetiva, convivência familiar, formação de redes sociais e conscientização sobre direitos de cidadania, configura-se como prática inovadora concretizada através da implantação do Projeto Janelas.

Os resultados expostos e analisados no capítulo anterior nasceram da articulação de sete categorias empíricas recortadas dos discursos dos sujeitos com algumas categorias analíticas apoiadas em Paulo Freire, Boaventura de Sousa Santos, Sérgio Resende Carvalho e Denise Gastaldo. As categorias analíticas escolhidas funcionaram como verdadeiras lentes organizadoras e significadoras dos conteúdos das entrevistas. Os principais resultados giram em torno de aspectos da formação recebida, das práticas educativas desenvolvidas com as equipes de saúde e as famílias e da percepção de impacto dessas ações com as famílias e comunidades.

Tanto a formação recebida quanto as práticas educativas desenvolvidas parecem ter sido ampliadas além do olhar biomédico porque incluem aspectos emocionais e relacionais de indivíduos, grupos e famílias. Todos os sujeitos identificam a abordagem crítico-participativa da formação que receberam e o impacto dela sobre suas atitudes e comportamentos, representando um processo de empoderamento com maior abertura para a escuta e algum tipo de transformação em suas práticas no sentido do empoderamento da população.

Especialmente em relação ao aspecto da incorporação de atitudes e condutas orientadas pelo respeito à autonomia da população entende-se que oscilaram 
entre valores normativos de manutenção e novos valores civilizatórios. Essa dialética regulação-emancipação variou de sujeito para sujeito, com uma preponderância perceptível do pólo da emancipação social.

Em relação ao impacto sobre o comportamento dos cuidadores familiares, as principais mudanças relatadas referem-se ao reconhecimento da importância da estimulação, da afetividade e do brincar infantil; maior disposição para conversar com as crianças; fortalecimento dos cuidados de higiene, prevenção de acidentes e participação do pai nos grupos educativos e nas consultas de pré-natal; entusiasmo em disseminar e orientar espontaneamente outras famílias da comunidade. Tais elementos se aproximam do conceito de competências familiares do UNICEF e revelam características importantes de famílias educadoras e promotoras de resiliência.

Os resultados encontrados permitem constatar que há uma importante lacuna na formação dos profissionais de saúde, lacuna essa que, se adequadamente compreendida, poderá embasar iniciativas com vistas à qualificação dos processos de educação permanente em saúde. Tal lacuna, muito mais do que certa falta ou carência de informações técnicas e científicas, refere-se à dimensão do 'aprender a fazer'. Seguindo os relatos dos sujeitos desta pesquisa, compreende-se que o processo ensino-aprendizagem deve acontecer dentro e fora da 'sala de aula' nos espaços acadêmicos e nos serviços simultânea e articuladamente - criando uma oportunidade ímpar de integração entre teoria e prática que resulta no exercício de uma práxis dialógica, com suas características essenciais de troca, compartilhamento e horizontalidade do poder sem negação das diferenças. Porque é neste processo dialógico que as diferenças vão sendo compartilhadas e aceitas ou rejeitadas. As subjetividades constituem-se assim no diálogo, questionam-se e atuam. Nasce a capacidade de reflexão crítica. 'Aprender a conhecer'. 'Aprender a ser'.

Também merece destaque constatar que o questionamento do modelo biomédico, onde o médico ou seu simulacro assume o maior poder pelo maior saber, cria uma possibilidade de aproximação real dos profissionais de saúde com a população. Essa aproximação vivifica o contato e faz cair determinadas máscaras e papéis 
sociais. Um contato assim mais real exige, por sua vez, uma postura de escuta. Quando as pessoas se vinculam, seus universos confrontam-se, desafiam-se, dialogam. Surgem dúvidas, angústias, incertezas, diferenças que até podem parecer intransponíveis. A necessidade de uma escuta qualificada é óbvia. Escuta sensível. Escuta-experimentação. Uma escuta que não nega a assimetria dos lugares que ocupam os profissionais de saúde e a população. 'Aprender a conviver'.

Estando a falha estrutural da formação dos profissionais da saúde mais localizada no 'aprender a fazer' do que no 'aprender a conhecer', em que pese a fragmentação do processo de produção e transmissão do conhecimento, esta falta instrumental agrava-se na medida em que cresce o hiato entre dois momentos de um mesmo processo: o da capacitação e o da atuação em serviço. Acrescente-se a isso uma avalanche de demandas cotidianas que coloca as pessoas muito sozinhas e sobrecarregadas, impedidas de pensar, de distanciar-se para refletir. Daí a necessidade de prover a sustentação do fazer profissional através de um cuidado efetivo que as redes de apoio que se formam com vistas à troca de informações e experiências podem oferecer. Essas redes são horizontais por natureza; nelas se constroem e fortalecem os laços afetivos entre seus membros, além de exercerem uma função de holding em momentos particularmente difíceis ou complexos.

Se, avançar no sentido de um agir em saúde de caráter mais emancipatório do que regulatório significa investir na formação em geral e na educação permanente em particular, tais processos formativos deverão articular conhecimentos que não fragmentem a compreensão do processo saúde-doença nem as práticas do cuidar em saúde; além disso, deverão promover o desenvolvimento de habilidades relacionais centradas na escuta, oportunizando a convivência e a aprendizagem em diferentes espaços dialógicos como a sala de aula, o serviço e a comunidade, num ir e vir dialético capaz de sustentar o novo, a transformação e a vida.

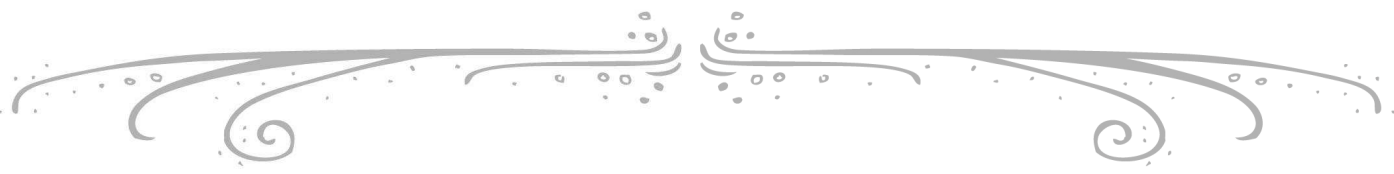




\section{REFERÊNCIAS BIBLIOGRÁFICAS}

Aguiar ZN. A qualificação dos atendentes de enfermagem: transformações no trabalho e na vida [dissertação]. São Paulo: Escola de Enfermagem, Universidade de São Paulo; 2001.

Ayres JRCM. Cuidado e reconstrução das práticas em Saúde. Revista Interface, Comunicação, Saúde, Educação, v.8, n.14, p.73-92, set.2003-fev.2004.

Barbier R. Escuta sensível na formação de profissionais de saúde. Conferência na Escola Superior de Ciências da Saúde - FEPECS - SES-GDF, Brasília, julho de 2002. Disponível através de http://www.barbier-rd.nom.fr/ESCUTASENSIVEL.PDF (acessado em 10.03.2010).

Bardin L. Análise de conteúdo. Lisboa: Edições 70; 1977.

Breilh J. Nuevos conceptos y técnicas de investigación: guia pedagógica para um taller de metodologia (epidemiologia del trabajo). Quito: Taller de Produción Gráfica ARCO IRIS, 1995.

Buss PM. Promoção da saúde na infância e adolescência. Revista Brasileira de Saúde Materno-infantil, Recife, 1(3): 279-82 set.-dez. 2001.

Cardoso de Melo JA. Educação sanitária: uma visão crítica. Caderno de CEDES no 4, São Paulo, Editora Cortez, 1981.

Carvalho SR. Os múltiplos sentidos da categoria 'empowerment' no projeto de Promoção à Saúde. Cadernos de Saúde Pública, Rio de Janeiro, 20(4):1088-1095, jul-ago, 2004.

Carvalho SR. As contradições da promoção à saúde em relação à produção de sujeitos e a mudança social. Ciência \& Saúde Coletiva, Rio de Janeiro, 9(3):669$678,2004 b$.

Carvalho SR. Saúde Coletiva e Promoção da Saúde: sujeito e mudança. São Paulo: Editora Hucitec, 2007.

Carvalho SR, Gastaldo D. Promoção à saúde e empoderamento: uma reflexão a partir das perspectivas crítico-social e pós-estruturalista. Ciência \& Saúde Coletiva, 13(Sup 2):2029-2040, 2008.

Chiesa AM. Autonomia e resiliência: categorias para o fortalecimento da intervenção na atenção básica na perspectiva da Promoção da Saúde. [tese de Livre-Docência]. São Paulo (SP): Escola de Enfermagem da USP; 2005.

Chiesa AM et al. Avaliação da implantação de novos instrumentos para o fortalecimento das ações de promoção do desenvolvimento infantil, na área de atuação do Programa Saúde da Família do Município de São Paulo. Relatório de Pesquisa. Ministério da Ciência e da Tecnologia; Conselho Nacional de 
Desenvolvimento Científico e Tecnológico (CNPq); Escola de Enfermagem da USP; UNIFESP - Departamento de Fisiologia. São Paulo, 2007.

Chiesa AM, Veríssimo MDLO, Fracolli LA. O projeto Nossas Crianças: Janelas de Oportunidades - possibilidades e limites para a atenção à criança. In. Chiesa AM, Veríssimo MDLO, Fracolli LA (organizadoras). Promoção da saúde da criança: a experiência do projeto Nossas Crianças: Janelas de Oportunidades. São Paulo: Editora Dedone, 2009.

Correia KMA. Avaliação da capacitação dos multiplicadores do projeto "Nossas Crianças: Janelas de Oportunidades", a partir da percepção dos sujeitos participantes do processo. [dissertação] São Paulo: Escola de Enfermagem da USP, 2007.

Delors J. et al. Educação: um tesouro a descobrir. Relatório para a UNESCO da Comissão Internacional sobre Educação para o século XXI. São Paulo: Cortez Editora, 1998.

Donato AF, Rosenburg CP. Algumas idéias sobre a relação Educação e Comunicação no âmbito da Saúde. Saúde e Sociedade, São Paulo, 12 (2):18-25, jul-dez, 2003.

Donato AF. Trançando redes de comunicação: releitura de uma práxis da educação no contexto da saúde. [tese] São Paulo: Faculdade de Saúde Pública da USP, 2000.

Dowbor TP. O trabalho com determinantes sociais da saúde no Programa Saúde da Família do município de São Paulo. [tese de doutorado]. São Paulo (SP): Faculdade de Saúde Pública da USP; 2008.

Feuerwerker LM. Modelos tecnoassistenciais, gestão e organização do trabalho em saúde: nada é indiferente no processo de luta para a consolidação do SUS. Interface - Comunic., Saúde, Educ., v.9, n.18, p.489-506, set/dez 2005.

Figueiredo LC. As diversas faces do cuidar: considerações sobre a clínica e a cultura. In. Maia MS. (org.) Por uma ética do cuidado. Rio de Janeiro: Garamond, 2009:121.

Freire P. Pedagogia do oprimido. 41를 ed. São Paulo: Editora Paz e Terra, 2005.

Freire P. Pedagogia da autonomia: saberes necessários à prática educativa. 36aㅗ ed. Paz e Terra: São Paulo; 2007.

Freire P. Professora sim, tia não: cartas a quem ousa ensinar. Olho d Água: São Paulo; 2007b.

Freire P. Educação como prática da liberdade. 32ª ed. Paz e Terra: São Paulo; 2009. 
Gastaldo D. É a educação em saúde saudável? Educação \& Realidade, 22:147-68, 1997.

Gazzinelli MF et al. Educação em saúde: conhecimentos, representações sociais e experiências da doença. Cadernos de Saúde Pública, Rio de Janeiro, 21 (1), janfev, 2005.

Giovanella L. et al. Saúde da família: limites e possibilidades para uma abordagem integral de atenção primária à saúde no Brasil. Ciênc. saúde coletiva [online]. 2009, vol.14, n.3, pp. 783-794.

Guerra IC. Pesquisa qualitativa e análise de conteúdo: sentidos e formas de uso. Parede - Portugal: Editora Principia, 2006.

Heckert ALC. Escuta como cuidado: o que se passa nos processos de formação e de escuta? In: Pinheiro R, Mattos RA. (Org.). Razões públicas para a integralidade em saúde: o cuidado como valor. $1^{\underline{a}}$ ed. Rio de Janeiro: ABRASCO/CEPESC, 2007.

Lalonde, M. A New perspective on the health of Canadians: a working document. Ottawa, 1974.

Lefevre F, Lefevre AMC. Saúde, empoderamento e triangulação. Saúde e Sociedade, São Paulo, 13(2): 32-38, maio-ago, 2004.

Merhy EE. Em busca do tempo perdido: a micropolítica do trabalho vivo em Saúde. In: Merhy EE, Onocko R. (orgs.) Agir em saúde: um desafio para o público. São Paulo-Buenos Aires: Hucitec-Lugar, 1997, p. 71-112.

Minayo MCS. O desafio do conhecimento: pesquisa qualitativa em saúde. São Paulo: Hucitec, 2007.

Oliveira AAP. Análise documental do processo de capacitação dos multiplicadores do projeto "Nossas Crianças: Janelas de Oportunidades" no município de São Paulo à luz da promoção da saúde. [dissertação] São Paulo: Escola de Enfermagem da USP, 2007.

Oliveira DL. A 'nova' saúde pública e a promoção da saúde via educação: entre a tradição e a inovação. Rev. Latino-am Enfermagem 2005 maio-junho; 13(3):42331.

Organização Pan-Americana de Saúde. Declaração de Alma-Ata. Disponível através de http://www.opas.org.br/coletiva/uploadArq/Alma-Ata.pdf (acessado em 08.03.2010).

PIDMU. Programa Infância Desfavorecida no Meio Urbano. Caminhos Metodológicos. CECIP. Rio de Janeiro, 2000.

Petrini JC, Alcantara M. A família em mudança. Bahia, 2001 (mimeo). 
Reyes WG, Abalo JG, Labrada MCP ¿Cómo hacer más efectiva la educación en salud en la atención primaria? Rev Cubana Med Gen Integr, Cuba, 15(2):176-83, 1999.

São Paulo. Secretaria Municipal de Saúde. Fundo das Nações Unidas para a Infância. Cartilha da família 'Toda hora é hora de cuidar'. São Paulo (SP); 2003.

São Paulo. Secretaria Municipal de Saúde. Fundo das Nações Unidas para a Infância. Manual de apoio 'Toda hora é hora de cuidar'. São Paulo (SP); 2003.

Sanicola L. Redes sociales y menores em riesgo. Buenos Aires: Lúmen Humanitas, 1996

Schall VT, Struchiner M. Educação em saúde: novas perspectivas. Cadernos de Saúde Pública, Rio de Janeiro, 15(suppl.2), 1999.

Shore R. Repensando o cérebro: novas visões sobre o desenvolvimento inicial do cérebro. Porto Alegre (RS): Mercado Aberto, 2000.

Solymos GMB, Maricondi MA, Soares MLPV. A criança e a família: as potencialidades da abordagem em rede para o contexto da promoção da saúde. In. Chiesa AM, Veríssimo MDLO, Fracolli LA (organizadoras). Promoção da saúde da criança: a experiência do projeto Nossas Crianças: Janelas de Oportunidades. São Paulo: Editora Dedone, 2009.

Santos BS. A crítica da razão indolente: contra o desperdício da experiência. In. Para um novo senso comum: a ciência, o direito e a política na transição paradigmática. Volume 1. 5aㅡ Ed. São Paulo: Cortez Editora, 2005.

Starfield B. Atenção Primária: equilíbrio entre necessidades de saúde, serviços e tecnologias. Brasília: UNESCO/Ministério da Saúde, 2002.

Soares MLPV. Rede Social no Centro de Recuperação e Educação Nutricional: uma proposta de abordagem metodológica com famílias. [dissertação] São Paulo (SP): Pontifícia Universidade Católica de São Paulo; 2001.

Stotz EM. Promoção da saúde e cultura política: a reconstrução do consenso. Saúde e Sociedade, São Paulo, 13(2): 5-19, maio-ago, 2004.

Trapé CA. A prática educativa dos agentes comunitários do PSF à luz da categoria práxis [dissertação]. São Paulo: Escola de Enfermagem, Universidade de São Paulo; 2005.

Vasconcelos EM. Educação popular como instrumento de reorientação das estratégias de controle das doenças infecciosas e parasitárias. Cadernos de Saúde Pública, Rio de Janeiro, 14(Sup. 2):39-57, 1998. 


\section{ANEXO A \\ Parecer do Comitê de Ética em Pesquisa}

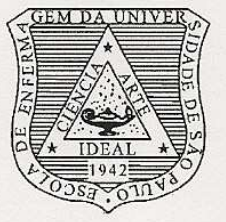

\section{UNIVERSIDADE DE SÃO PAULO ESCOLA DE ENFERMAGEM}

Av. Dr. Enéas de Carvalho Aguiar, 419 - CEP 05403-000 Tel.: (011) 3061-7548/8858 - Fax: (011) 3061-7548 São Paulo - SP - Brasil e-mail: edipesq@usp.br

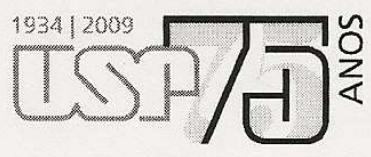

São Paulo, 25 de março de 2009.

$\mathrm{Ilm}^{\mathrm{a}} \mathrm{Sr}^{\mathrm{a}}$

Maria Angela Maricondi

Ref.: Processo $n^{\circ} 793 / 2009 /$ CEP-EEUSP

Prezada Senhora,

Em atenção à solicitação referente à análise do projeto "Caracterização das práticas educativas dos agentes multiplicadores do projeto nossas crianças: janelas de oportunidades com as equipes de saúde e as famílias", informamos que o mesmo foi considerado aprovado pelo Comitê de Ética em Pesquisa da Escola de Enfermagem da Universidade de São Paulo (CEP/EEUSP).

Analisado sob o aspecto ético-legal, atende às exigências da Resolução $\mathrm{n}^{0}$ 196/96 do Conselho Nacional de Saúde.

Esclarecemos que após o término da pesquisa, os resultados obtidos deverão ser encaminhados ao CEP/EEUSP, para serem anexados ao processo.

Atenciosamente,

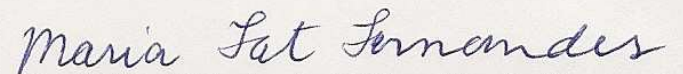

Prof. ${ }^{a}$ Dr. ${ }^{a}$ Maria de Fátima Prado Fernandes

Coordenadora do Comitê de Ética em Pesquisa da

Escola de Enfermagem da Universidade de São Paulo 


\section{ANEXO B \\ Conceitos centrais do Projeto Janelas}

CoMpetÊnCIAS FAMILIARES NA ATENÇÃo A CRIANÇAS dE ZERO A SEIS ANOS dO UNICEF

"Competências familiares são conhecimentos, saberes e habilidades que, somados à amorosidade de atitudes e práticas das famílias, facilitam e promovem a sobrevivência, o desenvolvimento, a proteção e a participação das crianças" (UNICEF, 2002).

São 28 competências organizadas em três áreas ou domínios.

Domínio 1: coesão da família em apoio à criança

(competências 1 a 5)

1. A família prioriza os cuidados com a criança, garantindo que a mãe ou responsável tenha controle sobre o orçamento. (Direito à sobrevivência, desenvolvimento, proteção e participação).

2. A família garante a participação do pai nos cuidados com a criança em atividades essenciais, notadamente durante o pré-natal, parto e o primeiro ano de vida. (Direito à sobrevivência, desenvolvimento e proteção).

3. A família estabelece e mantém uma rotina de atividades familiares com a criança. A família faz as mesmas atividades todos os dias nos mesmos horários. (Direito ao desenvolvimento).

4. A família evita que as crianças entrem em contato com os efeitos danosos do álcool e de outras drogas (desde o início da gestação e amamentação) e das brigas familiares. (Direito à proteção).

5. A família deseja a criança. (Direito à sobrevivência, desenvolvimento, proteção e participação). 
Domínio 2: comportamento familiar interativo em apoio à criança (competências 6 a 20)

6. A família garante que as crianças recebam alimentação normal balanceada segundo os alimentos disponíveis na localidade, e que sejam ricos em micronutrientes (vitamina $\mathrm{A}$, iodo e ferro especialmente). (Direito à sobrevivência).

7. A mãe oferece amamentação exclusiva desde a primeira hora do nascimento até os 6 meses conforme demanda da criança, aproveitando o momento da amamentação para fortalecer os vínculos mãe/criança. (Direito à sobrevivência e desenvolvimento).

8. A família inicia a alimentação ativa complementar aos 6 meses, oferecendo alimentos ricos em nutrientes e preparados de modo adequado e saudável, sem abandonar a oferta de leite materno até os 2 anos de idade ou mais. A família aproveita o momento das refeições para estreitar suas relações. (Direito à sobrevivência, desenvolvimento e participação).

9. Os membros da família falam, cantam e lêem para a criança, além de oferecer o máximo possível de materiais impressos com figuras e texto, estimulando assim sua linguagem e preparando-a para a leitura. (Direito ao desenvolvimento).

10. Os membros da família asseguram a reserva de um tempo adequado para passarem exclusivamente com a criança. (Direito ao desenvolvimento).

11. A família oferece oportunidades para a criança brincar com brinquedos e outros objetos da casa todos os dias. (Direito ao desenvolvimento).

12. A família oferece tratamento adequado à criança doente em casa, assegurando a continuidade da alimentação e a oferta abundante de líquidos, inclusive leite materno. (Direito à sobrevivência). 
13. A família sabe do que se constitui um exame de pré-natal e reconhece sinais de alerta e de perigo durante a gestação, o parto e o pós-parto. (Direito à sobrevivência).

14. Os membros da família lavam as mãos antes da preparação de alimentos, antes de alimentar as crianças e, principalmente, após a defecação. (Direito à sobrevivência).

15. A família protege as crianças e as gestantes em áreas atingidas por malária e/ou dengue usando mosquiteiros impregnados ou outros métodos de proteção. (Direito à sobrevivência).

16. Os membros da família ouvem a criança desde bem pequena e encorajam sua participação em suas decisões, especialmente aquelas relevantes para ela, isto é, que the dizem respeito. (Direito à participação).

17. A família oferece oportunidades para a criança se socializar, brincar e aprender a conviver com outras crianças de sua idade. (Direito ao desenvolvimento e participação).

18. A família pratica uma disciplina positiva para reorientar os comportamentos não desejados da criança. (Direito ao desenvolvimento).

19. A família protege a criança de acidentes domésticos. (Direito à sobrevivência e proteção).

20. A família assegura o uso apropriado da televisão discutindo com a criança o tempo e os programas adequados para ela. (Direito ao desenvolvimento e participação). 


\section{Domínio 3: uso de serviços / rede social} (competências 21 a 28)

21. A gestante utiliza os serviços de pré-natal, parto e pós-parto, acompanhada por algum membro da família, de preferência o pai da criança. (Direito à sobrevivência, desenvolvimento e proteção).

22. A família assegura que a criança tenha o registro civil e a certidão de nascimento assim que nascer. (Direito à proteção).

23. A família estabelece redes informais com outros membros da família e vizinhos para cuidar das crianças em situações excepcionais ou imprevistas, como doença, greve na creche ou escola, ausência dos pais. (Direito à proteção).

24. A família identifica e utiliza os serviços de saúde, educação, assistência social e sistema de garantia de direitos existentes, participando de sua gestão. (Direito a sobrevivência, desenvolvimento e proteção).

25. A família identifica em sua vizinhança e em seu município os serviços de saúde, educação, assistência social e sistema de garantia de direitos não existentes, demandando e participando de sua criação (Direito à sobrevivência, desenvolvimento, proteção e participação).

26. A família providencia para que as crianças sejam completamente imunizadas (BCG, DPT, OPV e sarampo) de acordo com sua faixa etária. (Direito à sobrevivência).

27. A família garante que as crianças recebam suplementação de micronutrientes: vitamina $A$, iodo e ferro especialmente. (Direito à sobrevivência).

28. A família reconhece quando uma criança doente precisa de tratamento em hospitais ou centros de saúde, levando-a a esses serviços. (Direito à sobrevivência). 


\section{FAMÍLIA}

Família... pessoas que se vinculam afetivamente e se relacionam em um espaço de convivência íntima...

Famílias que ouvem, conversam, estimulam e dão limites para a criança - com amorosidade -promovem desenvolvimento e resiliência.

No modelo patriarcal de família, as funções materna e paterna estão separadas, cristalizadas e hierarquizadas. Será um modelo em crise?

$\checkmark$ A família está em processo de profundas transformações;

$\checkmark$ Não existe um modelo certo ou errado de família a ser seguido ou combatido;

$\checkmark$ Existem muitos "modelos" ou arranjos familiares diferentes;

$\checkmark$ As formas como as famílias se organizam e os princípios e regras que regem suas relações são muito variados nas diferentes culturas e sociedades.

\section{RESILIÊNCIA}

É a capacidade de recuperar e manter um comportamento adaptado após um dano.

É um conceito emprestado da Física que, quando aplicado à Psicologia, significa:

$\checkmark$ Resistência a experiências negativas;

$\checkmark$ Não é uma capacidade inata; ela depende da interação dos cuidadores com a criança;

$\checkmark$ Não pressupõe características excepcionais de saúde nem experiências de vida predominantemente boas;

$\checkmark$ Depende de uma exposição controlada ao estresse e às adversidades psicossociais. 


\section{PATRIMÔNIO}

Indica um conjunto de recursos dos quais as pessoas podem dispor para garantirem, a si mesmas e a seus familiares, maior segurança e melhor padrão de vida. Tais recursos compõem-se de trabalho, saúde, educação, moradia, habilidades pessoais e relacionais - relacionamentos familiares, de vizinhança, de amizade, comunitários e institucionais ${ }^{15}$.

\section{Rede Social da Família}

É constituída de um conjunto de relações interpessoais a partir das quais a pessoa e /ou a família mantêm sua própria identidade social. Esta identidade compreende hábitos, costumes, crenças e valores característicos de uma determinada rede. $\mathrm{Da}$ rede social a pessoa e lou família recebe sustento emocional, ajuda material, serviços e informações, tornando-se possível o desenvolvimento de relações sociais. A diversidade das redes depende de como elas foram originadas e dos bens que nelas circulam (reciprocidade, dinheiro, direito). (Soares, 2001)

${ }^{15}$ O PIDMU / Programa Infância Desfavorecida em Meio Urbano, com o objetivo de contribuir para a melhoria das condições de vida de crianças e adolescentes em situação de risco pessoal e social, foi implementado por ONG's nas cidades de São Paulo, Rio de Janeiro, Salvador, Recife e Belo Horizonte durante três anos, tendo sido concluído em abril de 2000. 


\section{ANEXO C \\ INSTRUMENTO DE Coleta de DADOS}

PARTE 1. Norteadores das narrativas dos sujeitos

1. No campo das suas práticas educativas, o que mudou em você do Projeto Janelas pra cá? E o que não mudou porque você já tinha?

Aspectos relevantes para observação:

$\checkmark \quad$ Se as mudanças relatadas são internas (de atitudes, conceitos, valores) ou externas (comportamentais);

$\checkmark \quad$ Se houve mudança de percepção acerca dos saberes e valores de classe; se afirmativo, em qual direção?

2. Fale-me (mais) sobre as suas práticas educativas de 2004 para cá.

Aspectos relevantes para observação:

$\checkmark$ Onde o entrevistado coloca a ênfase de suas experiências como educador (aquisição de conhecimentos; desenvolvimento de reflexão crítica; atividades participativas; exercício de diferentes pontos de vista; relações familiares, profissionais, de amizade e vizinhança; consciência política, participação comunitária, etc.).

3. Descreva com mais detalhes a prática educativa que você considera ser a mais significativa.

Aspectos relevantes para observação:

$\checkmark \quad$ Nos conteúdos manifestos e latentes do discurso; ler texto e subtexto.

4. De quais outras experiências de formação, posteriores ao Projeto Janelas, você participou como educador (a) e como educando (a)? Em quais aspectos elas foram interessantes e significativas para você?

Obs. orientar a escuta colocando foco na relação, na interação humana, cuidando sempre para não induzir o entrevistado. 
Aspectos relevantes para observação:

$\checkmark \quad$ Se por interesse ou necessidade

$\checkmark \quad$ Se por oportunidade

$\checkmark$ Se por iniciativa própria ou estímulo de colegas, familiares ou instituição empregadora

$\checkmark$ Dificuldades e facilidades para acompanhar ou ministrar o curso / oficina de formação.

PARTE 2. Questionário para caracterização dos sujeitos participantes

1. Sexo

( ) masculino ( ) feminino

2. Idade

( ) menos de 25 anos

( ) de 26 a 30 anos

( ) de 31 a 35 anos

( ) de 36 a 40 anos

( ) de 41 a 45 anos

( ) de 46 a 50 anos

( ) mais de 51 anos

3. Etnia/Raça/Cor

( ) branca

( ) parda/morena

( ) preta/negra

( ) amarela/indígena

4. Grau de escolaridade

( ) fundamental completo

( ) fundamental incompleto

( ) médio completo

( ) médio incompleto

( ) superior completo Qual?

( ) superior incompleto Qual? 
5. Formação profissional

( ) especialização em

( ) mestrado em

( ) doutorado em

( ) outro(s) Qual (is)?

6. Possui especialização em Saúde da Criança ou similar? Indicar onde e ano da conclusão do curso:

7. Cargo ou função que ocupava à época da implantação do Projeto Janelas (2004):

8. Cargo ou função que ocupa atualmente (2009):

9. Indicar experiências anteriores ao Projeto Janelas como 'agente multiplicador':

10. Indicar experiências posteriores ao Projeto Janelas como 'agente multiplicador':

Data:

Local:

Assinatura: 


\title{
ANEXO D
}

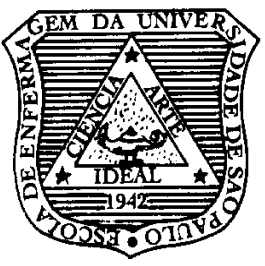

\author{
UNIVERSIDADE DE SÃO PAULO \\ ESCOLA DE ENFERMAGEM \\ DEPARTAMENTO DE ENFERMAGEM
}

EM SAÚDE COLETIVA

Av. Dr. Enéas de Carvalho Aguiar, 419 - CEP 05403-000

Tel.: (011) 3061-7652

\section{TERMO DE CONSENTIMENTO LIVRE E ESCLARECIDO}

Eu, Maria Angela Maricondi, aluna de mestrado em Enfermagem em Saúde Coletiva da Escola de Enfermagem da Universidade de São Paulo, estou desenvolvendo a pesquisa intitulada Caracterização das práticas educativas dos 'agentes multiplicadores' do Projeto Nossas Crianças: Janelas de Oportunidades com as equipes de saúde e as famílias, sob a orientação da Profa. Dra. Anna Maria Chiesa, cujo objetivo é o de conhecer as práticas educativas desenvolvidas por esses profissionais, de 2004 até o momento atual. Tendo você vivenciado tal processo como 'multiplicador', sua colaboração é muito importante e por isso solicito a sua participação. Seu consentimento deverá considerar que: (a) o relato de sua experiência pessoal no âmbito dessas mesmas práticas ocorrerá em situação de entrevista individual; (b) será necessário gravar para transcrever na íntegra as informações fornecidas por você em tal situação; (c) sua participação é voluntária, sendo possível interromper o processo de entrevista a qualquer tempo se, por alguma razão, assim o desejar, e tal fato não lhe causará qualquer prejuízo; (d) nada será cobrado ou pago por esta sua participação.

Você poderá solicitar informações adicionais sobre este trabalho diretamente à pesquisadora, bem como contatar a EEUSP através de seu Departamento de Enfermagem em Saúde Coletiva pelo telefone 30617652 ou de seu Comitê de Ética em Pesquisa através do telefone 3061 7548. Por ocasião da divulgação dos dados, será mantido sigilo de sua identidade e, conseqüentemente, a confidencialidade de suas informações.

Concordando em participar, por favor, assine este documento, e receba uma cópia do mesmo.

$\mathrm{Eu}$,

concordo

em

participar da pesquisa sobre práticas educativas dos 'agentes multiplicadores' do Projeto Janelas.

São Paulo,

12009

Ass. 


\section{ANEXO E \\ Mapa da Implantação do Projeto Janelas}

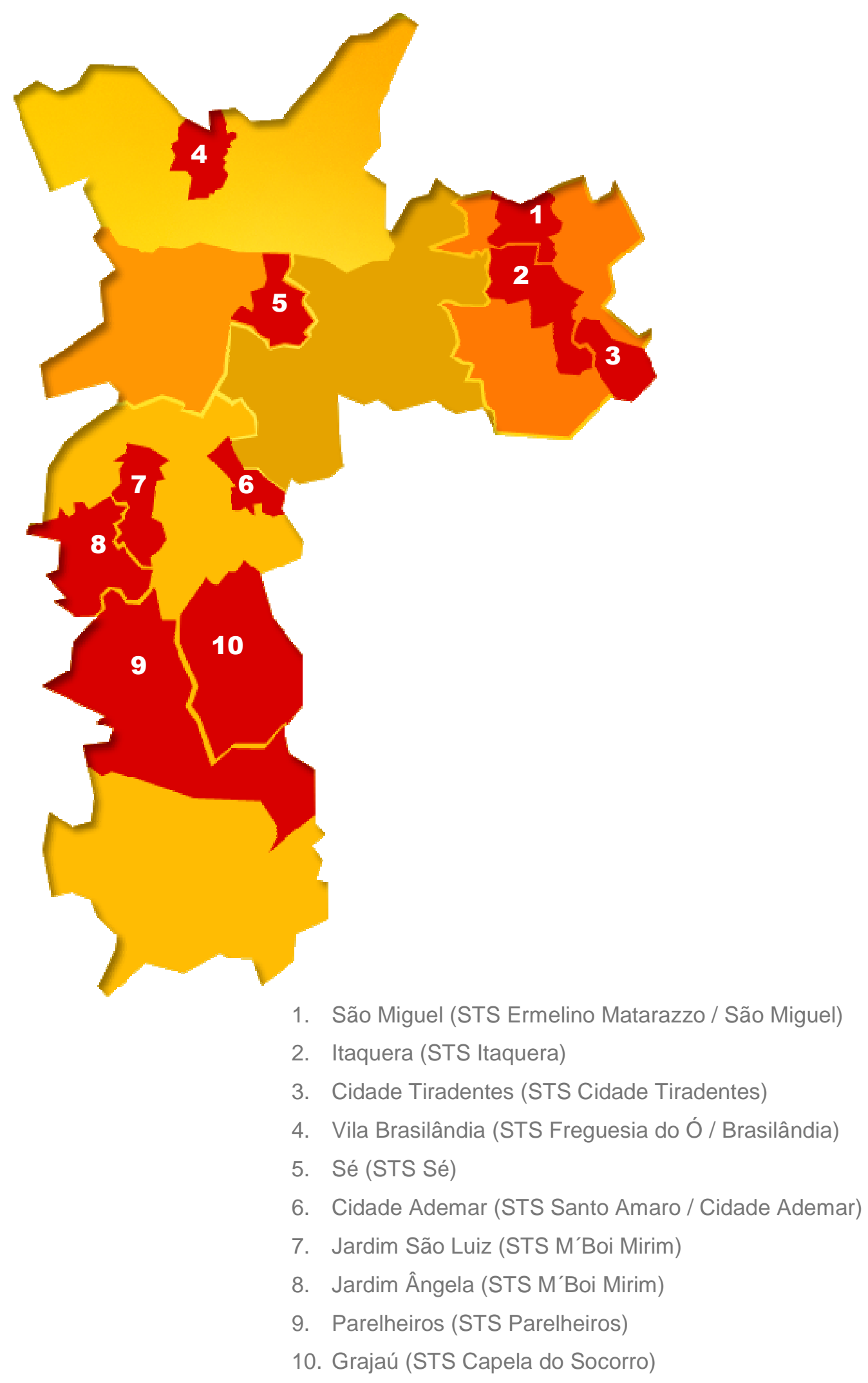




\section{ANEXO F}

\section{As ENTREVISTAS}

Entrevista ํo 1 realizada em 11.05.2009 (duração: 51 minutos)

Local: consultório particular

Angela: Eu queria que você me contasse o que mudou em você, em relação às suas práticas educativas, do 'Janelas' prá cá. E o que permaneceu igual, porque você já tinha? Fale-me dessa experiência no sentido da mudança, se houve alguma mudança, descreva um pouco isso, tá?

S1: Eu acho que houve mudanças sim, Angela. Na minha avaliação, eu acho que foi uma das melhores capacitações que eu fiz até hoje. Eu sempre tive um pezinho na educação, muito embora eu tenha uma formação na psicologia, mas assim, sempre estou às voltas com as práticas educativas, seja na sala de aula, seja como professora, seja na Prefeitura, muito embora na Prefeitura eu não seja efetiva como psicóloga; eu sou AGPP, ou seja, administrativa, e continuo como administrativa, e fui fazer aquele curso porque na Prefeitura é aquela coisa, não tem concurso, não tem concurso de acesso, e aí, até porque pela formação em psicologia, naquela época, a minha gerente me deu a oportunidade de participar desse curso, era o momento da implantação do PSF na Unidade, para depois ser multiplicadora com as agentes comunitárias, e depois disso eu acabei saindo da Saúde. Eu saí em 2004, em junho de 2004; estou na Assistência Social, que é outro lugar que também requer toda uma vivência, um conhecimento de práticas educativas, né? E assim, tenho feito outros cursos nesta linha, inclusive com algumas instituições que são de formação mesmo de educadores sociais. $O$ que foi muito legal, é que, assim, depois de todo esse trajeto, a validade desse curso do 'Janelas', essa capacitação, porque deu prá comparar... (Conta um pouquinho!) Então é assim, o que eu gostei muito no 'Janelas', a gente tinha aí a questão das vivências nas oficinas, seja a partir de trabalhos gráficos, seja através da vivência corporal, a gente teve várias experiências, e eu sempre tive uma reserva, muito embora fosse psicóloga, eu sempre tive uma reserva, não era uma coisa que eu gostasse bastante; eu acho importante, mas eu acho que tem uma medida, e em muitas capacitações que a gente participa eu acho que há um uso excessivo dessas dinâmicas e que acaba sendo uma chatice mesmo. E lá, o que eu gostava muito é que a gente tinha vivência, mas a gente tinha conteúdo teórico, e isso para mim é muito importante, atrelar uma coisa a outra, né? E quando eu falo que hoje eu comparo é que eu participei de formações com outras organizações, que desenvolvem exatamente isso, dentro dessa perspectiva, mais vivencial, de práticas de educação não formal, dentro desta perspectiva mais vivencial, e aí me irritava muito porque ficava só na vivência, o tempo todo, e quando você precisava que a discussão começava a pegar e você precisava embasar isso com as questões mais conceituais, mais teóricas, ou mesmo aprofundar as discussões, aquilo [não] era ouvido porque a gente já tinha outra vivência em seguida, tinha um cronograma de horário e a gente tinha que estar fazendo outras vivências ( $E$ ela entra meio que ela por ela mesma). Sim, ela pode até trazer um sentido pra gente 
e a gente conseguir transpor pras nossas práticas, mas eu acho que às vezes falta aprofundamento, discussão, debate, um aporte teórico mesmo, inclusive em uma das organizações que eu fiz, eu comecei dois cursos, o primeiro eu fui até quase o final, fiquei sem o certificado porque eu não agüentava mais, né? Depois, passado um tempo, fui inscrita para outro curso pela própria Secretaria, comecei a fazer e era a mesma instituição, com as mesmas técnicas, do mesmo jeito. Fui um mês e não fui mais. Então, quando eu falo que eu pude comparar com o 'Janelas' é nesse sentido, e fora isso, hoje, no meu trabalho como Supervisora Técnica de serviços conveniados com a Prefeitura, em que trabalho exatamente com práticas sócioeducativas, ou seja, com idosos, famílias, crianças, adolescentes, jovens, eu trago muito daquela experiência para a minha atuação enquanto Supervisão Técnica.

Angela: Ah, sim, pelo que estou entendendo você colocou muito um aspecto de aproveitamento da própria capacitação no sentido de fazer sentido, de estar integrada nas várias atividades dentro do próprio corpo da oficina. Na sua prática cotidiana, o que você poderia identificar como sendo o que mais contribuiu, o que mudou para vc, até no sentido do seu trabalho de Supervisão?

S1: Eu acho que hoje, dentro da nossa Secretaria, o foco são as famílias, né? Eu acho que muito embora essa capacitação tenha sido feita em 2003 e 2004, a gente fez um resgate aí. Eu já estava formada há algum tempo, a gente tem sempre aquela coisa, tava ainda naquele modelo da família nuclear, e a gente foi vendo que na prática não é nada disso. Então, aquele momento serviu como um disparador mesmo de reflexão. E hoje, quando eu vou para os serviços, eu vivencio ainda muito daquilo que a gente discutiu lá atrás, seja na questão do que são as famílias hoje, seja nas questões sociais, muito embora tenha sido uma capacitação para a área da Saúde, eu acho que a gente peneirou e entrou por várias vezes, não dá para dissociar, nas questões sociais. Hoje, a gente tenta de toda forma articular a rede. Então, o que é isso? Buscar a Educação, buscar a Saúde, porque as demandas vêm de todos os lados, né? Então, eu vivo me deparando, eu chego ao serviço para a Supervisão, e aí a gente tem as questões da Saúde travando alguns encaminhamentos dos serviços, e, assim, quando eu me lembro de toda aquela experiência e da própria multiplicação que a gente fez com as agentes comunitárias e de tudo o que a gente conseguiu passar para elas, de vê-las amadurecendo e tal, então, eu tenho plena confiança em buscar o PSF como referência para subsidiar o nosso trabalho. A gente está recorrentemente buscando ações articuladas com o PSF.

\section{Angela: Você está na mesma região do Jardim S. ?}

S1: Não, eu estou na Subprefeitura de M. e lá nós somos... Agora chegaram mais assistentes sociais... Nós estamos agora em 14 técnicos e cada técnico é responsável por um território de supervisão; eu estou com aquele pedaço que a gente chama de Fundão, bem longinho, e é um lugar assim, onde todas as práticas educativas se fazem necessárias, não só as práticas educativas e sim todos os recursos sociais.

Angela: Estou entendendo que você está valorizando bastante os conteúdos teóricos (do 'Janelas'), que são atuais, que são aplicáveis nas várias áreas, não 
apenas na Saúde, aplicáveis na Educação também, na Assistência Social, enfim, você está me dizendo que a qualidade dos conhecimentos adquiridos, do ponto de vista teórico, da informação mesma, articulados com as vivências, que tudo isso é algo que ajudou na sua formação, que você vem fazendo outros cursos e pode fazer um comparativo.

S1: Hoje, por exemplo, a gente também tem dentro da nossa profissão a atribuição de capacitar os profissionais do serviço - se eles solicitam, a gente pode - a gente não faz isso, não vem fazendo, pelo menos porque a gente tava ai até o ano passado com um número de profissionais muito reduzido pra dar conta, tanto da supervisão técnica dessas parcerias quanto do atendimento ao munícipe e de todos esses programas sociais que estão ai, tava muito, a gente não estava dando conta de tudo isso. Chegaram mais profissionais e a idéia é exatamente resgatar isso, a gente poder inclusive estar fazendo esse papel de formação dentro do serviço (Vc quer dizer que vai poder iniciar agora). É, a gente espera, porque você sabe que dentro do poder público as coisas surgem, mudam, de repente você faz todo um script de trabalho e de repente vem outra coisa, um programa, alguma coisa que você precisa implementar com urgência e tudo aquilo vai ficando pra depois. Mas, esta é uma das nossas atribuições. Eu me lembro muito dos 'Janelas', tanto é que eu tenho todo o material guardado, inclusive as folhinhas com os planejamentos, eu tenho tudo muito guardado, e me ajudou inclusive nisso, porque muito embora eu tenha sido professora, e a gente tem aquele modelo da escola, de fazer os semanários, é tudo muito seco, conteúdo tal, aplicar dessa forma - esse era o modelo que eu tinha - eu uso aquele modelo (do 'Janelas') até hoje, quando eu preciso desenvolver qualquer coisa. Inclusive estes dias, eu voltei das férias, e com a equipe nova que chegou eu tive que falar um pouco sobre supervisão técnica com os novos colegas, e até como montar eu uso aquele material (Ah, sim, que interessante!). Porque eu acho que é uma ferramenta, que é bastante detalhada, não é aquela coisa seca, tem mais flexibilidade, inclusive dá para ir trabalhando com o que vai emergindo, você tem ali uma seqüência, tem inclusive a divisão dos horários, mas ela é uma coisa que não te engessa, né? Se, de repente, você precisa não aplicar uma dinâmica que está ali prevista - isso é uma das coisas que eu achei muito rica no processo de capacitação - se a gente precisar de repente dar uma segurada em alguma coisa, porque quer aprofundar a discussão, isso é possível.

Angela: Tá valendo, não é para ser uma camisa de força, pelo contrário, é para dar um norte. Isso você pôde fazer na multiplicação - que não é uma multiplicação, uma replicação - que na verdade é uma adaptação à realidade de cada um ali.

S1: Naquele momento, quando foi para capacitar os agentes comunitários de saúde, é claro que a gente faz algumas adaptações em função do espaço físico, em função do tempo, em função do próprio momento, porque precisa fazer isso dentro da Unidade, então isso tem um diferencial, mas não perdeu a sua riqueza.

Angela: E me conta uma coisa: você fez, lá trás, a formação dos agentes e da equipe como um todo, trabalhou a Unidade toda, e chegou a acompanhar pessoalmente o trabalho com as famílias ou ficou mais no processo formativo? 
S1: Nos primeiros meses eu consegui acompanhar, mas depois eu saí da Saúde para ir para SAS, e aí ficou a M. acompanhando, que era a outra colega. Porque foi feita a capacitação com os profissionais em um sábado. Então, o que nós fizemos? Nós demos uma enxugada em tudo aquilo e ficou em um sábado o dia todo. Foi muito interessante porque eu estava morrendo de medo, porque iam os médicos, enfermeiros, e você sabe o quanto é difícil às vezes, muito embora eu tendo a formação em psicologia, lá dentro eu era uma auxiliar administrativa ( $V c$ era vista como ATA, me lembro bem de como vc se apresentou na oficina). Então, eu estava com muito receio, muitos médicos do PSF super novos, alguns que chegavam com uma certa arrogância; tinha outros que, por outro lado, não tinham essa arrogância, eram colegas antigos, mas eram pessoas que estavam há anos no trabalho, e você vinha com uma proposta de discutir além do papel médico, uma proposta que discutia outras questões e que o pessoal tinha que fazer uma mudança de paradigma na realidade. Eu tava com muito receio, então eu preparei aquilo com muito carinho, estava eu e a M. - a gente sabe que para o pessoal que trabalha na Equipe de PSF é muito complicado ter tempo para fazer outras atividades, especialmente essa - então, na verdade, eu acabei preparando quase que sozinha; a M. estava do meu lado nos dias para me dar, mas toda hora era interrompida, isso porque a equipe solicitava, o usuário; nesse sábado não, porque a atividade foi no sábado, e foi muito legal. Eu saí de lá super feliz, isso me deu gás, uma autoconfiança, porque o pessoal ficou o dia todo lá, foi possível prender a atenção das pessoas, foi um despertar de interesses. Eu usei muito as dinâmicas que nós usamos na capacitação e as pessoas se envolveram mesmo, participaram, deu um suporte legal para as discussões, e foi meio que um despertar pra certas pessoas que vão ficando aí. E teve uma outra questão que foi muito legal, foi que eu saí um pouquinho desse lugar de ATA quando terminou. Muitas pessoas depois vieram conversar comigo dizendo:_Nossa, eu não sabia que você tinha essa facilidade pra dar aula.

Angela: Porque você exercia essa função administrativa de fato, não estava em desvio de função. Eu me lembro muito bem quando você falou, na oficina, que tinha um cargo de ATA, mas era psicóloga. O tempo vai passando e as lembranças vão ficando apagadas; eu não tinha clareza se você estava em desvio de função ou se você trabalhava mesmo como administrativa.

S1: Eu trabalhava como administrativa.

Angela: Assim, entendo bem como essa experiência te colocou em um outro lugar dentro da Unidade.

S1: Isso me deu uma autoconfiança para depois poder trabalhar com as agentes, muito embora eu estivesse menos ansiosa em trabalhar com elas, porque para mim era como se eu estivesse indo para a sala de aula, os alunos que tem menos 'know how' aí. Então, o meu grande receio era trabalhar com os profissionais.

Angela: Especialmente os médicos, né? [risos gerais]. Como é que eles vão receber essa história de trabalhar além do biológico, né? 
S1: É, especialmente os médicos. Tinha um médico que era bastante - uma pessoa ótima, mas era dono de um saber, que era muito peculiar - ele ficou o dia todo lá conosco, contribuiu bastante, então isso foi muito legal.

Angela: Este ponto me interessa muito, a tua percepção em relação a alguma alteração de prática educativa em você, e nos outros com quem você trabalhou. Bem, vc acabou de pontuar, neste médico parece que a arrogância se alterou naquele processo, quebrou o gelo, começou a ser mais receptivo, acompanhou, não foi embora. Você tem mais elementos, alguma coisa interessante que você tenha identificado?

S1: Em um segundo momento a gente ia capacitar os agentes comunitários e isso deu uma validade para o projeto, a questão da seriedade, não era mais uma coisa que vinha né? Porque eles faziam as reuniões de equipe, eles também iam ter que estar dentro do projeto; então, isso assegurou uma validação do projeto, o fato de você ter sensibilizado inicialmente esses profissionais que de alguma forma estão ali no seu lugar, eles foram privilegiados (E vocês começaram por ai, para depois formar os ACS). Nós fizemos, acho, que cinco encontros de oito horas cada um, seguindo mais ou menos aquele roteiro, aquele modelo que a gente experimentou lá, com algumas adequações, inclusive de dinâmicas, por conta do espaço físico e tal. Também foi muito rico. Num primeiro momento foram mobilizadas muitas questões internas, pessoais desses agentes comunitários, porque era um modelo novo, então eles traziam questões vividas nas suas visitas domiciliares, era lidar com a impotência frente a determinadas situações, com a angustia de ir na casa da pessoa e se deparar com as faltas, as privações, as dificuldades e, por outro lado, a questão de como lidar com essa prática nova naquele modelo novo de saúde que estava sendo proposto, mas que ainda tinha muito resquício do modelo anterior dentro dessas equipes. Então, eles traziam muitas angustias, e aí a gente percebeu que no primeiro e no segundo encontros eles precisavam falar, falar dessas angústias, de uma mistura, né? Como eles moravam no território, mais particularmente dentro das micro-áreas pelas quais eles eram responsáveis, não tinha uma dissociação aí do que era o funcionário, do que era o vizinho; eles traziam muito que no final de semana as pessoas iam até a casa deles, à noite, super tarde, para resolver os problemas que teriam que ser resolvidos na UBS, e a dificuldade de se colocar como profissional nesse momento e de perceber que aquela não era a hora, aquele não era o momento, e que ali eles não eram os ACS, e sim pessoas cuidando das suas famílias também.

Angela: Você está me falando de um primeiro ponto que era este, o de perceber nitidamente uma mudança interna, mais no campo afetivo, é isso? E pra você, também aconteceu assim? No seu processo como é que isso apareceu para você, nos processos de formá-los, você identifica alguma coisa nova, significativa? Porque tem toda essa contribuição teórica, conceitual, mas tem também, isso que você está falando em relação a eles, uma contribuição que mexe em outro campo, que é do afeto, da reflexão sobre si. Com você isso também aconteceu, eu suponho pelo que vc está me falando. Enfim, teria uma tradução aí que poderia caracterizar uma nova prática de educação, como educadora? 
S1: Eu acho que o que foi possível mudar, que eu nem sei se é uma mudança, porque a gente sempre tem aquela coisa de rever, voltar, quando eu te falo que a gente não se sente engessada por um planejamento, acho que esse foi um momento quando eu comecei a captar que essa angustia precisava ser ouvida, que a gente precisava refletir sobre isso, e a gente foi permitindo.

Angela: Olha, veja se eu entendi, veja que interessante. Você é psicóloga, você tem uma formação diferenciada do modelo biomédico, não tava tendo um espaço para executar, praticar o que você sabe fazer. $O$ 'Janelas' te trouxe esses conteúdos, essa possibilidade, então eu estou entendendo que você pôde desabrochar nisso, trazendo o que você já podia, mas não tinha lugar para fazer. Pôde facilitar que esses processos ocorressem com os agentes comunitários de saúde. Com os demais profissionais de saúde foi mais uma sensibilização, eles se engajaram, talvez não muito, é isso? Ou bastante?

S1: Eu acho que até bastante, eu avalio como bastante.

Angela: Mas o maior investimento de formação foi feito com os ACS.

S1: Sim, se esse espaço não fosse propiciado, eu acho que a gente não caminharia. Eles estavam num nível de angústia, você imagina, eram uns quarenta ACS, não me lembro bem a quantidade, mas era um grupo grande de ACS; nós tínhamos onze equipes, não lembro se nesse momento a gente tava com nove equipes e depois entraram mais duas, só sei que era um número grande de equipes. Todos os ACS trazendo essas angústias, sem nenhum lugar pra falar sobre isso, porque as reuniões de equipe que ocorriam diariamente eram pra falar exatamente dos encaminhamentos da semana, do dia, que tal caso precisa de visita. Não tinha espaço pra falar de si dentro desse processo [do PSF], então eu senti que se a gente não permitisse um momento dessa capacitação pra isso, a gente não andaria. $E$ foi muito rico, foi muito válido.

Angela: A M. que fazia dupla com você, ela também acompanhou esse processo. Fico me perguntando se os agentes aprenderam alguma coisa disso, será que eles conseguiram levar isso até as famílias de alguma forma?

S1: Acho que sim, até depois, pelo próprio acompanhamento que a gente fazia. A gente fazia reuniões, eu não me lembro da periodicidade, eram reuniões de acompanhamento (Onde este jeito, esse processo de trabalho era sustentado). Então fez sentido, mexeu muito com eles. E foi... ah, tá, tinha uma outra experiência que depois eu vivi, depois de eu estar lá na SAS, ainda com a Saúde. la ter uma capacitação de agentes, capacitação não, uma formação, uma qualificação para técnicos, para eles se tornarem técnicos como agentes comunitários de saúde, que era um Programa do Ministério. Eu já estava na SAS e Dra. S. me convidou. Eu tinha acabado de entrar, negociei com minha chefia e fui trabalhar como docente da Escola Técnica, eu fiquei um semestre com a turma. Nós fizemos uma capacitação também pra isso. E foi muito interessante porque eu fui trabalhar com os mesmos ACS, na realidade com os mesmos e outros da região, porque as turmas eram mistas, eram de algumas Unidades do entorno da UBS X. E são momentos muitos especiais. Aí já era uma coisa mais conceitual 
mesmo, porque tinha apostila, a gente tinha que avaliar, mas tinha também todo aquele conteúdo trabalhado de uma forma vivencial, talvez um pouco menos vivencial que o 'Janelas'. Aí deu pra perceber a diferença de como essa capacitação foi feita em outras Unidades, porque nós tínhamos os nossos agentes comunitários de saúde e tínhamos agentes comunitários de outras Unidades que também passaram pelo processo de capacitação do 'Janelas'.

Angela: E você identificou diferenças?

S1: Diferenças de como essas multiplicações foram feitas.

Angela: Você diria que tem a ver com esta oportunidade de trabalhar com o emocional?

S1: Também. Eu acho que tem diferença nesse sentido, acho que em termos de duração, porque a gente tentou seguir, meio que na íntegra, o que a gente recebeu, a importância que foi dada a essa multiplicação nas diferentes UBS, qual o lugar que ela ocupou. Então, vc via que em umas tinha um lugar de um pouco mais de destaque do que em outras, pelo que os ACS nos traziam, comentavam: _Ah, na capacitação... Porque também a gente falou de SUAS, falamos de família, então alguns dos nossos falavam e os outros complementavam. Então, duração, como foi feito. Eu percebia pelo que alguns agentes traziam, que em algumas foi muito enxuta, uma coisa seca (Muito reduzida, né? Aí não pegou). Não sensibilizou. Não pegou. Este também foi um parâmetro.

Angela: A subjetividade está em discussão na Saúde, ela é importantíssima pra você superar o modelo biomédico, você tem que trazer à luz as vivências, os vínculos, a responsabilização profissional pelo outro, e isso tudo está aí pra gente pensar. Essa oportunidade de trabalhar mais a fundo, de um jeito que pegue 0 outro de uma forma mais significativa, parece ser uma coisa fundamental para que qualquer projeto caminhe. Mas, eu também me pergunto sobre um outro tipo de sentido, mais social. Vc identifica na sua experiência, do 'Janelas' pra cá, algum sentido assim, alguma mudança de valores? É que já falamos do campo intelectual, conceitual, do afetivo. E sobre os valores, a convivência comunitária, a relação do profissional de saúde com a população, a posição dele na relação? Essa questão da arrogância e do autoritarismo que vc já apontou...

S1: Só vou resgatar outra questão de que estava te falando anteriormente. Quando eu te falo que consigo perceber essa diferença dos modelos de capacitação, eu acho que não é somente pelo fato de ser psicóloga ou não, porque as pessoas são capazes de fazer as coisas, mas eu alio isso ao fato de que talvez eu estivesse mais disponível também em termos de tempo, né? Porque os enfermeiros tinham seus afazeres com suas equipes, aquelas demandas todas, e eu como ATA, deslocada de lugar para fazer isso, pude me dedicar pra fazer isso, coisa que talvez os outros profissionais não tivessem tido a oportunidade. Então, esse foi um fator bastante importante. Agora, em relação aos valores, Angela, acho que teve sim, inclusive para mim. (Como?) Vou pegar esse exemplo da família, talvez porque foi uma das coisas com que a gente iniciou e que me marcou muito. A 
gente vem vivendo as coisas, as mudanças sociais, aquela coisa toda, e vai vivendo no dia a dia, às vezes uma coisa incomoda aqui, outra ali, mas a gente vai fazendo; e naquele lugar que eu estava tava muito tranqüilo, como ATA fazendo um trabalho administrativo, tudo bonitinho. Eu trabalhava mais na parte que a gente chamava de 'expediente dois' que era junto com a Administração e com o $\mathrm{RH}$, então, mais ali com os funcionários; a minha experiência com munícipe era um pouco mais distante. Então você vai caminhando naquele mundinho e não vai refletindo muito sobre as coisas que estão aí à tua volta. Quando a gente foi para aquela capacitação, o que me marcou muito quando a gente começou a discutir família, entrou modelo do PSF, foi assim, opa, cai a ficha. Porque às vezes a gente fazia algumas críticas, porque acontece isso, a criança faz aquilo, isso independente do meio profissional, na família, nas nossas discussões com os amigos. E aí cai a ficha. Opa, o modelo mudou! Eu acho que a gente já sabe, mas a gente não discute. Então, prá mim foi muito importante, porque eu acho que eu pude amadurecer tudo isso, que já tava ali incomodando e eu não tinha permitido espaço para pensar sobre isso. Aí fez todo sentido porque muda toda a tua concepção frente as pessoas, frente as situações, frente ao que você observa no âmbito social, e aí, conseqüentemente, muda valores. Então, quando a gente começa a discutir como articular rede, que já era uma discussão que vinha, hoje a gente ainda está se debatendo nisso, sempre se debate nisso, eu pude pensar um pouquinho melhor sobre isso, dessa importância, então tudo isso muda valores, muda o olhar quando você começa a discutir as recomendações dentro de um modelo médico, que é o que a gente vive dentro de uma Unidade Básica de Saúde, em relação a alimentação, aos cuidados, e ai você vai vendo que lá fora essa família, às vezes, não tem condições de dar aquilo que é recomendado lá dentro, e aí você começa a perceber aonde é que está essa distância, o que pontua essa distância, e isso certamente muda valores, muda o olhar.

Angela: Você identificaria mais alguns temas que mexeram com vc, que resultaram nessas mudanças significativas?

S1: Ah, acho que até a questão da violência, que foi um dos temas que a gente passou, ficou muito marcado pra mim. Quando a gente trabalhou, não me lembro do conteúdo, acho que a gente trabalhou a questão da adolescência, da violência, daquele menino daquela música, o 'Meu Guri'. A gente trabalhou um pouco essa música, esse olhar para essas questões.

Angela: Seria no sentido de prestar mais atenção, de sensibilizar, o que mais?

S1: Acho que muda a postura. (Postura? Explica mais). Porque a partir do momento em que você muda o seu olhar, você muda a forma de você entender e enxergar as pessoas, as situações, o modelo que está posto aí, você também muda o seu modo de agir, a sua postura em relação ao outro, em relação a determinados encaminhamentos que se faz.

Angela: Eu estou insistindo um pouco, este tema é delicado, particularmente esse da violência contra a criança. O que você identifica que possa ter mudado um comportamento seu? 
S1: Muitas vezes a gente vai pelo senso comum, e como eu te falei, na minha trajetória eu fiquei meio extasiada durante um período com tudo isso, com aquela questão de ser ATA, trabalhava com educação infantil, então eu estava assim, meio que naquele mundinho, e quando a gente participou e fez aquela discussão, aquele debate, muito embora eu tivesse algumas idéias a respeito disso, mas nunca foi uma coisa que a gente tem, muitas vezes a gente se vê levada a pensar pelo senso comum. Quando a gente adentrou as questões da violência - eu me lembro muito daquela música, do que a gente discutiu, foi muito forte - aí a gente vê a violência ir se construindo e começa a pensar com um pouco mais de profundidade, isso muda a forma de você entender como essa violência surge, isso faz com que, tudo bem, ali foi um momento, foi um dos capítulos da capacitação que a gente teve, mas te faz buscar mais elementos. E eu me recordo que comecei a me interessar pelo ECA, que depois disso eu fazia voluntariado no CEDECA, que é um centro de defesa da criança e do adolescente que atendia crianças em situações de violência, violências gerais e especificamente violência sexual, então foi super útil, aquilo fez muito sentido. Tinha um trabalho lá com famílias, eu comecei a pensar na produção dessas violências diversas. Mais pra frente, agora como técnica de um grupo de proteção psicossocial que trabalha com adolescentes com medidas sócio-educativas em meio aberto - LA, PSC - eu acho que de uma situação ali, você vai refletindo, e é engraçado como as coisas vão acontecendo na sua vida, eu não sei se vão acontecendo ou se a gente vai buscando, você se sente mais instrumentalizada, mais cutucada e aí também você vai buscando. Quando eu penso no processo de voluntariado fui eu que fui buscar, ele não veio me chamar; o NPP não, foi uma coisa que veio mais em função do trabalho; mas, mesmo os outros serviços que a gente supervisiona, a gente trabalha com crianças em situação de risco e vulnerabilidade social, crianças em situação de rua, então eu acho até mesmo que essa coisa de ter topado ir para a Assistência Social foi uma das coisas que, quando te falei de mudança de valores, de atitudes, eu acho que provocou sim.

Angela: Ficou claro para mim. Olha que eu não tinha pensando nisso, nesse tipo de resultado.

S1: Eu acho que essa capacitação foi uma cutucada, eu sempre falava que ia fazer uma faculdade de Serviço Social. Hoje eu vejo que não preciso fazer faculdade de Serviço Social. Depois que eu entrei na Assistência, eu não preciso. ( $A$ Educação vem a calhar... [risos]). Vem, faz todo o sentido, pra mudar o seu olhar, sua abertura, não precisa ter necessariamente formação especifica.

Angela: Você está aí formando pessoas, como eu... Fiz clínica psicanalítica durante quinze anos, não sei se te contei isso alguma vez...

S1: Não. Não! [risos]

Angela: Sim, sou colega sua de profissão, fiz todo um percurso de psicanalista, começando com análise de crianças, depois de adultos, e depois resolvi - não consegui articular assim, como você, ambas as coisas, ou bem estou numa coisa ou noutra, não consigo juntar - desde 1990, resolvi largar a atividade de consultório, deixando assim de acompanhar pessoas com muita proximidade e 
profundidade para entrar em um campo de intervenção macro, das políticas públicas e, mais recentemente, em 2001, através da Monte Azul, nas políticas públicas de saúde, especificamente no PSF, que foi quando conheci vocês. Fui aprender Saúde da Família acompanhando as equipes das unidades de saúde daquela região, as reuniões com agentes comunitários de saúde. Eu também morria de medo de me confrontar entre aspas com os médicos, eles pareciam Deuses! [risos]. Fui assim tocando o processo de construção de uma fase nova da minha vida, no campo da educação, da formação, e estou agora às voltas com o meu mestrado, pesquisando as práticas educativas dos profissionais com quem a gente trabalhou no 'Janelas', as suas práticas educativas neste nosso diálogo... Bem, voltando a você, como você trabalha com as pessoas para promover alguma mudança nelas, nessa direção do afetivo, da mudança de valores, que são mudanças bastante significativas?

S1: Acho que é partir de uma escuta qualificada mesmo, viu Angela, porque eu acho que essa mudança de olhar, essa mudança de leitura, atrelada à questão da formação também faz... ah, e um olhar crítico também, eu acho que é muito importante, porque às vezes eu brinco no Serviço, lá na Assistência: Ah, meu Deus, que lugar é esse aonde eu vim parar! Eu me incomodo com essa posição acrítica que as pessoas têm, num lugar onde eu esperava, pelo menos, que tivesse isso muito forte (Mais desenvolvido que na Saúde?). Eu esperava sim, tanto é que, quando me convidaram, putz, que legal, vou trabalhar com pedagogo, psicólogo, assistente social... Me decepcionei re-don-da-men-te!. Hoje eu escuto a assistente social defendendo redução de maioridade penal! Isso me deixa... e algumas posições... Então, nas reuniões de equipe, eu penso:_Ah, não vou nem falar nada, porque você acaba sendo chata. Mas não dá prá gente não falar nada, acabo me contrapondo. Mas eu não vejo isso como uma coisa negativa, eu acho que eu não conseguiria ser de outro jeito. Lembra quando a gente falou da questão do consultório, da clínica? Eu acho que eu ainda trago muito desse olhar aqui para dentro, mesmo atendendo pessoas de outra classe social, eu acho que as políticas públicas perpassam a vida das pessoas o tempo todo. Então, por exemplo, quando eu atendo pessoas em cargos executivos de empresas, a gente pega aí a crise que as empresas vêm vivendo e as pessoas atordoadas. Não é à toa que tem tanta depressão, síndrome do pânico, ta-ra-ra-ta-ra-ra, isso tem um reflexo nas pessoas. E aí, mesmo não sendo pobre, sendo diferente daqueles com quem a gente trabalha nos grupos educativos e sócio-educativos, é possível fazer uma leitura do impacto disso na vida também dessas pessoas.

Angela: E como você faz isso? Você aponta a relação de classe, do patrão e do empregado?

S1: É tão engraçado o consultório, ele tem uns movimentos... e a gente brinca muito aqui... tem época que você recebe muita gente com depressão, são períodos, parece um problema do momento. Teve um período aqui que começaram a surgir muitas pessoas atordoadas com a pressão do trabalho. Eu tinha uma paciente que falava que ela se via presa com algemas de ouro, que ela não suportava mais o local onde ela trabalha, com muita competitividade, mas ela não podia sair por conta do salário, dos benefícios, do isso, do aquilo, do aquilo outro. Não dá prá dizer que o social não está envolvido aí, que a questão político- 
social e econômica não está envolvida aí. É claro que você não vai fazer nenhum discurso sociológico, aquela coisa toda, mas vai fazer com que as pessoas percebam determinadas relações.

Angela: $A$ isso é que você está chamando de escuta qualificada articulada com alguns aspectos da vida social? Nem que seja só para você, que você não vá dizer aquilo naquele momento. É nesse sentido?

S1: É, esse é o universo, e até mesmo... No mês passado, eu fui participar de uma reunião com famílias de pais de um dos serviços que eu acompanho. A idéia era que eu fosse falar um pouco da Política da Assistência dentro daquele serviço, porque como a gente tem muito convênio com organizações religiosas, então fica aquela coisa de que é a igreja quem dá o curso para o garoto. Então, a gente vai falar um pouquinho desse conveniamento, qual o papel da Assistência Social lá dentro, que é um serviço gratuito, que tem que ser laico, que a política pública é isso - é claro que você fala com outras palavras para as pessoas compreenderem - depois de eu ter falado do que é SUAS, o que era aquele curso, um curso de informática, ta-ra-ra-ta-ra-ra-ta-ra-ra. Aí o pessoal do serviço falou da questão mais técnica do funcionamento, era reunião de primeiro bimestre, tal. Aí um pai levanta a mão e:_Ah, eu queria agradecer muito a vocês, agradecer muito a Prefeitura por essa ajuda que está dando pra gente. Aí eu pedi para intervir e falei: _Olha, isso não é uma ajuda, isso é um direito seu, o senhor falou há pouco que não tem dinheiro para pagar curso para os seus filhos, que o senhor não tem dinheiro para pagar uma faculdade, mas o senhor está pagando os impostos! Aí, você olha e todo mundo parece que se empondera de alguma coisa. Esse pai, assim, foi como se... você vê mudança na postura, no olhar, sabe aquela coisa, aquele lugar de se sentir reconhecido, ele não tá ali pedindo um favor, ele não está recebendo um favor. Isso é muito rico, eu acho que isso é um salto.

Angela: Valeu! Muito bom. Eu te agradeço muito.

S1: Ah, eu espero ter contribuído... 
Entrevista № 2 realizada em 27.05.2009 (duração: 47 minutos) Local: na Unidade de Saúde

Angela: No campo das suas praticas educativas em saúde, o que mudou em você do Projeto Janelas pra cá? E o que não mudou, porque você já tinha?

S2: É, eu realmente já tinha um histórico de práticas educativas em saúde. Sempre tive bastante interesse e sempre procurei introduzir em todos os locais que eu trabalhei e eu realmente consegui trazer isso. O 'Janelas' trouxe um conteúdo assim, muito importante, trouxe novos conhecimentos, e parece que ele trouxe a organização de idéias que em alguns momentos parecia que eu queria colocar na minha prática, mas não tinha uma coisa pronta, parece que não tinha uma coisa autorizada. É como se o 'Janelas' tivesse me autorizado a trazer conteúdos pra minha pratica que pra mim já eram muito importantes: a questão da humanização, a questão do afeto, a questão do vínculo que em alguns momentos eu até poderia ter trazido, porque eu já sou formada há muitos anos e, na época da minha formação, a questão que era exigida de nós, alunos de enfermagem, era uma postura emocional que não se envolvesse com o paciente.

Angela: A neutralidade, né?

S2: Aquela neutralidade, o que não tinha nada a ver comigo. Então, na época em que eu fiz a graduação eu já tive alguns embates com alguns professores. Por exemplo: com minha professora de pediatria. Eu fiz meu estágio de administração em pediatria na cirurgia pediátrica da Santa Casa. E naquela época não tinha alojamento conjunto. Então, as crianças eram arrancadas da mãe, ficavam lá pra fazer uma cirurgia que fosse, sei lá, de uma fimose e, às vezes, por conta dessa separação ficavam febris, e no dia seguinte a cirurgia era suspensa. Então, isso pra mim era uma coisa péssima. Era inadmissível pra mim, como se pode arrancar alguém assim, né? Impor a uma mãe e uma criança esse sofrimento! Então, naquele estágio [de pediatria], eu já era muito afetiva, sempre gostei muito de criança. Eu ficava com a criança no colo, eu pegava, eu tentava amenizar, sabe, e isso era muito mal visto! Eu tive a minha nota de pediatria baixa. Ela só não deu uma nota mais baixa porque eu era uma boa aluna, eu tinha sempre notas boas, mas ela me falou disso na minha avaliação. Então, parece que a sua formação já te desautorizava a trabalhar conteúdos que parece que não fazem parte da saúde, o que na minha visão não era (Não combinava com você). Não combinava, não combinava com a minha experiência de vida, com a construção de um trabalho que a gente quer fazer, e aí eu acho que tanto o PSF como o Projeto 'Janelas' trouxeram uma autorização, pra quem acredita nisso, pra você investir realmente, valorizar e trabalhar muito com eles, né? Então, tanto desde que eu estou no PSF, tanto depois com o 'Janelas', isso me trouxe uma estruturação. Então hoje, eu não trabalho mais com a ficha, hoje eu tenho pouquíssimas cartilhas, eu tenho só algumas que eu guardei, porque eu usei o máximo que eu pude no grupo de gestantes, no grupo de crianças. Mas, todo o embasamento que o 'Janelas' usou pra construir esse projeto, todo esse trabalho, eu acho que permeia muito o meu trabalho. 
Angela: Entendi, é como se tivesse ressoado em você. Acho que a gente contribuiu pra trazer alguma organização no que você já tinha.

S2: Exatamente! Uma organização, um fortalecimento. É lógico que alimentar, porque a gente aprendeu muito com o material do 'Janelas', com todo o conteúdo. Até hoje eu tenho os slides do 'Janelas', aqueles que falam da estruturação cerebral, da questão do estimulo, sabe? E quando tenho que fazer alguma coisa eu uso, eu uso muito! Uso muito com o grupo de gestantes que a gente tem que é muito legal. Então, eu acho que trouxe realmente um alimento, uma organização, novos conhecimentos, uma coisa muito boa. É isso que eu queria te contar, não sei se fica pra depois ou agora (Conte sim, conte agora). Eu usei muito isso porque eu fui professora do Módulo I do Curso Técnico de Agente Comunitário de Saúde. Fui uma professora que formou 15 ACS desta unidade e 15 ACS da UBS T. E esse curso, que tem toda uma estruturação muito legal, pena que esteja parado, né? Parou. O Módulo 1. E até hoje eles cobram. Eles me chamam de 'prô': _'Prô, e o curso?' E eu não sei do curso. Eu usei muito todo esse embasamento, todo esse alimento que o 'Janelas' me trouxe, eu usei muito pra discutir com eles várias questões da visita, do olhar, das relações, o trabalho do apoio... Eu acho que ele faz parte da minha vida, realmente.

Angela: Eu acho que uma segunda questão faz parte naturalmente da continuidade do que você já está dizendo. Fale mais dessas práticas educativas que você vem fazendo nestes últimos quatro anos, de 2004 para cá.

S2: Então, de 2004 prá cá eu continuo fazendo o grupo de gestantes. É um grupo que realmente acontece, tem uma estrutura, tem todo um ritual aceito aqui, tanto pelos profissionais, porque primeiro eu cheguei aqui, e de onde eu vim eu já fazia o grupo, já fazia alguns encontros, e a experiência vai trazendo, você vai aprimorando, procurando sempre estar inovando. Então, é um grupo que a gente oferece, são quatro encontros, a gente divide por assuntos; e a gente trabalha muito na consulta [de enfermagem], os agentes nas visitas, a auxiliar [de enfermagem] quando vai na minha consulta ou na consulta da médica da equipe, que é um grupo que a gente chega a falar que faz parte do pré-natal, que é obrigatório como uma consulta de pré-natal, que não pode ser abandonado. É lógico que algumas vêm e não querem sair; outras a gente precisa fazer um esforço danado pra que venham e nunca vem; e quando vem, depois gostam e continuam vindo...

\section{Angela: Do que você acha que depende essa continuidade ou não no grupo?}

S2: Primeiro, elas darem abertura pra conhecer o que você está oferecendo, porque elas não têm idéia do que é que você está oferecendo. Normalmente, elas têm uma idéia de que você vai lá ouvir uma palestra. Nosso grupo não é uma palestra. E depois, eu acho que é você saber mostrar pra elas a quê você está dando tanto importância. É um produto, um grupo de gestantes. É o que eu falo pras minhas agentes comunitárias, que não adianta ir lá combinar de vir, fingir que está vendendo um produto. A gente tem que sensibilizar essa grávida pra que ela tenha força, porque a gestante precisa ter força. Não é uma questão de 'ah, eu não quero porque não tenho interesse'. Dentro do contexto de cada pessoa, ela precisa 
ter muita força pra conseguir vir no grupo, pra vir aqui e receber. E aí, quando elas vêm e começam a participar, a gente percebe ao longo dos encontros elas desabrocharem. Então, são quatro encontros: no primeiro encontro, a gente faz uma apresentação, uma dinâmica pra descontrair, elas se apresentam, e tem um momento em que elas também falam sobre como foi saber da sua gravidez. Aí, umas falam que ficaram muito felizes porque planejaram, outras se sentiram péssimas, infelizes, por não quererem a gravidez, ou foram abandonadas pelo parceiro, [enfim] tem mil histórias, né? Normalmente também aparece a questão de não querer o filho, sofrendo porque é um momento de vida dela que tá muito difícil, não foi uma gravidez planejada, e ao mesmo tempo elas se sentem culpadas:_'Como eu, mãe, tô rejeitando um filho? Um dia eu quis ou um dia eu vou querer, sei lá, né?' E depois disso a gente faz algumas discussões no sentido de trabalhar elas mesmo, assim, de olharem pra elas, saberem que a questão da rejeição não acontece só com elas, que pode acontecer com qualquer mulher, com qualquer pessoa, de trazer pra elas que a própria gravidez traz realmente uma sensibilidade maior, há toda uma mudança hormonal. O significado da gravidez na vida de uma mulher também deixa a mulher muito fragilizada, porque a vida nunca mais vai ser como antes mesmo, né? $\mathrm{E}$ daí elas perceberem que precisam ter um pouco de paciência com elas, de aceitarem esse momento, né? $\mathrm{E}$ acho que o fato delas perceberem que não é só elas, que nós não estamos condenando o fato delas não estarem querendo, mas sim apoiando, aceitando, recebendo aquilo, entendendo o momento delas, eu acho que isso já se torna mais confortável pra elas, elas já começam a ter um vínculo diferente com você. Porque realmente tem muito disso, tem umas que estão grávidas do sétimo filho e chegam aqui morrendo de vergonha: _'Como é que você não procurou a gente antes?' Às vezes o agente tem que insistir muito pra elas virem fazer o pré-natal, porque elas ficam com vergonha da gente, como se o nosso papel fosse o de oferecer a crítica ou o julgamento por aquilo que está acontecendo na vida delas. E quando elas percebem que não é isso, que não acontece assim, eu acho que elas já começam a ter uma relação diferente com você.

\section{Angela: O vínculo...}

S2: É. E depois desse momento, no mesmo dia, a gente faz um momento em que elas fazem uma rodada - algumas vivenciam, outras não - perguntando: _'O quê que vocês desejam pro filho de vocês?'. Elas todas falam que sejam inteligentes, lindos, que vão bem na escola, la-la-la-la-la, elas vão falando. Aí, a gente começa a discussão: 'E quem que vai ajudar essas crianças então, depois que crescerem, a conquistar tudo isso?'. Aí elas pensam:_'Acho que nós, né?'.

_Mas de que jeito?'. E a gente vai tentando provocar, discutir. Aí vem a questão do vínculo, vem a questão do estímulo, do estímulo positivo, do estímulo negativo, como que começa a preparar a questão do vínculo através da barriga, como nasce uma criança, e vem muitos conceitos do 'Janelas'. Que uma criança não nasce pronta... daí a gente fala de uma criança que não tenha problemas de má formação, que não tenha nada, que o cerebrozinho dela está pronto, mas que precisa começar a fazer as ligações [sinapses]. A gente vai falando de um jeito... _'E como é que isso se faz?'. A gente fala das 'janelinhas', que com a estimulação, dependendo do que a criança está experimentando, vão se abrindo algumas 'janelinhas', que no futuro vão ajudar na escola, vão ajudar nisso, naquilo, no 
vínculo com as pessoas, num monte de coisas. E elas começam a falar da questão do afeto. _'E como é que a gente vai estimular? Aí elas vão trazendo - o amor, carinho, o cuidado com a higiene, não sei o que, la-la-la-la-la-la, essa coisa mesma do vinculo, das relações, é onde elas começam a perceber a importância de conversar com o bebê dentro da barriga, de pensar nomes. E muitas, nesse primeiro dia, nem falam, se apresentam com muita dificuldade por conta da timidez, por conta do momento de sofrimento. Aí, quando você vai pro segundo grupo - isso aconteceu nesse grupo que está tendo agora, e quinta feira vai ser o quarto encontro desse grupo - eu sinto que elas vão desabrochando. Então, você vê aquela que não falava nada, que ela está ali pra se colocar... E a gente pergunta: _'Você quer falar do que está levando, do que trouxe, como está se sentindo?'. Elas dão depoimentos... A gente nunca registrou esses depoimentos. A gente está pensando agora que a gente tem que registrar. Afinal, é um trabalho que a gente faz, né?

\section{Angela: Daria um material maravilhoso!}

S2: Daria um trabalho maravilhoso. Aí a gente vai fazendo os encontros e em todos os encontros a gente vai trabalhando muito a questão do vínculo, do afeto com a criança como alimento fundamental, como proteção da saúde mental da criança, a gente traz alguns exemplos, e aí a gente vai trabalhando.

\section{Angela: E por aí vai até o ultimo encontro?}

S2: Sim, até o último encontro.

Angela: Pelo que eu estou entendendo, você alia tudo ali, no vínculo, na estimulação, já articulando os conteúdos com os cuidados.

S2: Com os cuidados, exatamente. Então, em todos os encontros a gente fala de vínculo, de afeto. Agora a gente tem uma TV de plasma lá; eu trago o meu notebook, com coisas que eu pego, imagens bonitas, textos, músicas, coisas de amamentação que eu mostro pra elas, que elas adoram! Em todos os encontros a gente permeia esta questão do vinculo, do afeto.

Angela: Então, essa é uma pratica que se mantém na sua...

S2: Na minha vida profissional. No grupo de gestante que, ao longo dos anos foi se aprimorando. E todo esse conteúdo do 'Janelas' contribuiu muito.

Angela: Você teria outras práticas para...

S2: A gente faz grupos de mães, grupos de crianças. O grupo de crianças a gente sempre faz, o que muda é a faixa etária. Nós estamos fazendo agora, do mês de maio ao mês de junho, toda segunda-feira, um grupo de crianças maiores - de sete, oito, nove anos - que é uma idade em que elas já não aparecem muito, que elas só aparecem quando estão doentes. Tem famílias que procuram, aquelas que são mais cuidadosas, mas normalmente são crianças que não são vistas. $E$ o que a gente tem ouvido das escolas dos arredores são muitas queixas de crianças com 
dificuldade escolar. Nós recebemos até as fichas das escolas. Quais são as crianças? Quando você pega a ficha das crianças que eles mandaram: _'Ah, essa criança é filho de fulana de tal, uma pessoa que faz acompanhamento de saúde mental com a gente; tem uma questão familiar desse rapaz que tem todo um processo de saúde mental ligado a uma mãe que o domina, etc.'. Você começa a entender o que está acontecendo com essa criança lá na escola, e a gente já queria mesmo ver essa criança mais de perto. Então, a gente tem feito esses grupos de segunda feira, e eu tenho discutido com o pessoal do NASF [Núcleo de Apoio ao Saúde da Família] porque eu estou muito preocupada. 'O que é que tem chegado?'. Além da questão alimentar que é absurda, porque hoje a cultura é de valorizar 0 industrializado - e esse industrializado está substituindo muito as refeições principais - então a gente está tendo criança dessa faixa etária com muita anemia. $O$ que os pequenininhos não estão tendo mais porque vêm todo mês com a gente, estes maiores, que vão ficando mais distantes, estão tendo. $\mathrm{E}$ outra coisa que a gente tem percebido e que está me preocupando é a questão da falta de habilidade, de recurso [relacional] que essas famílias tem nas relações com essas crianças, de maus tratos - emocionais e morais - de na frente do grupo chamar a criança de burro, de gorda, de que come mesmo... um caso no grupo da segunda feira retrasada de uma criança de oito anos que chega em casa com fome e ela só vai almoçar às três horas porque ela não almoça enquanto ela não faz o trabalho doméstico. Um trabalho doméstico de lavar toda a louça, varrer a casa, limpar o fogão, e daí pra frente. Isso porque a mãe não quer que a criança fique preguiçosa, porque 'o tipinho dela é ser preguiçosa'. Isso de uma mãe falando de uma criança de oito anos. E aí a gente percebe que - e isso ficou muito claro pra mim - é realmente a pobreza nessa questão das relações familiares, o empobrecimento nessa relação maternal em alguns casos - é lógico que a gente não está generalizando, porque tem aquelas mães super amorosas que vem - e tem aquelas que são [amorosas] em excesso, outras superprotetoras, o que também é complicado. Mas nós temos casos aqui de mães amorosas, batalhadoras, mulheres que estão aí - que são malabaristas - tentando fora, dentro, tanta coisa, e são amorosas e que tem essa relação legal.

\section{Angela: Sim...}

S2: Nós fazemos também como prática educativa o grupo de planejamento familiar que, do ano passado pra cá, começou a ser mensal e para toda a unidade. Antes, esse grupo de planejamento cada equipe fazia o seu. E aí a gente percebeu que cada mês um enfermeiro faz, né? [era melhor]. A gente começou a fazer agora terapia comunitária. Com a vinda do NASF, a gente tá começando a aprender essa prática com o pessoal que veio e que tem essa experiência. Os grupos de hipertensos e diabéticos, [onde] a gente também sempre traz esta questão [que] eu chamo de postura emocional, que jeito, que postura que eu tenho diante da vida que pode me adoecer ou não, essas coisas pra trabalhar um pouco a questão emocional, essas discussões que são fundamentais pra controle de qualquer doença crônica. Então, a gente tem isso, a gente tem feito, não com muita freqüência, mas a gente tem feito grupo de meninas pequenas que começaram a menstruar. Porque aí fica a mãe ansiosa, a criança também, e a gente faz um grupo de menininhas pra conversar sobre as mudanças do corpo, como se cuidar, [sobre] esse momento, pra não ficar só, porque algumas vêm felizes, outras vêm 
como se tivesse acontecido a pior coisa da vida. Sem nenhuma orientação. Tem mães que conseguem orientar, tem mães que não conseguem orientar.

Angela: que idade?

S2: Nove, dez, onze, doze anos, que é uma faixa etária que ainda não está desperta, são aquelas que não estão ainda voltadas pro sexo, pra questão da sexualidade, estão no momento anterior.

Angela: São grupos de conversa? Tem alguma coisa lúdica?

S2: Não. A gente faz uma coisa interativa, colocando música pra elas, elas falam; é participativo. Todas as nossas praticas educativas aqui são participativas. Eu não sei fazer...

Angela: Como você alinhavaria todas estas praticas que você me contou? Uma característica seria essa, ser pratica participativa. Teria mais alguma característica?

S2: Ser participativa, de uma forma bem descontraída, buscando a proximidade. Eu acho que nessas faixas a gente consegue construir um vínculo. Que nem no grupo de gestantes, uma coisa que a gente faz, já há muitos anos, a gente providencia um lanche pra elas. Porque é um grupo [em] que elas acabam ficando um período grande, elas almoçam e vêm. Grávida tem mais fome. Nesta região, que a gente sabe que a condição socioeconômica... às vezes você vai na visita na hora do almoço e você vê que não tem nada, não vê uma fruta, nada, né? Você sabe, eu nem preciso entrar em detalhe com relação a isso. Então, a gente providencia um lanche - um suco, fruta, alguma coisa salgada - e elas adoram. Então fica aquela mesa ali, pra elas se servirem.

Angela: Isto faz parte do cuidado, né?

S2: Isso, faz parte do cuidado. No grupo de gestante a gente consegue manter isso. Esse grupo de gestante, quando eu cheguei aqui, é que eu venho da UBS $X$ pra cá, era só um grupo da equipe $B$, que é a minha equipe. Eu fazia, minhas gestantes vinham, sempre vinham, porque a gente fazia um esforço enorme pra vincular elas a esse grupo. As outras equipes olhavam meio de longe, os enfermeiros não estavam num momento muito maduro de troca, e a gente foi crescendo, passando por algumas dificuldades, e conseguimos adquirir um momento de mais proximidade e troca. Aí, chegamos num momento que eu comecei a oferecer vagas, porque as agentes comunitárias estavam tão interessadas no grupo, quando estavam grávidas elas queriam ir, tinha agentes grávidas de outras equipes que vinham e perguntavam se podiam ir, e a gente falava que sim, que podia. Aí eu comecei a oferecer vagas pra algumas equipes que eram mais abertas, e essas equipes começaram a mandar. Enquanto isso, os enfermeiros foram crescendo, evoluindo também, então hoje o grupo não é só mais da equipe B. O grupo de gestantes é da UBS $Y$, porque todas as equipes mandam, sabem as datas e podem mandar; então, o grupo não tem só as nossas gestantes, tem de todas as equipes. 
Angela: Entendi.

S2: E os enfermeiros começaram a entrar pra ver como era.

Angela: E aí você começou algum trabalho com eles?

S2: E aí eles começaram a participar, e eu deixo o espaço aberto pra todos os que vão - se tiver alguma coisa que eu esqueci de falar, falar; se tiver alguma coisa que quiser assumir, assumir. Então, tem a enfermeira da equipe B que agora ela assumiu o dia em que se fala do parto. Ela tem uma experiência hospitalar, fez obstetrícia, ela traz um conteúdo legal sobre o parto humanizado, ela assumiu isso. De um jeito assim, que ela adorou! Tem os outros enfermeiros vindo, mas que não têm muita habilidade ainda com o grupo, ainda se sentem um pouco [inseguros] mas acabam dando alguma contribuição. Neste ultimo grupo, os profissionais do NASF entraram pra conhecer e já fizeram uma prática de relaxamento com elas, quer dizer, nós estamos num momento que, conforme você vai conseguindo essas adesões, que as pessoas se sintam à vontade pra trazer sua experiência, com certeza eu acho que é um momento maravilhoso, porque cada um tem uma riqueza e as pessoas estarem abertas pra levar isso pro grupo com certeza é uma experiência que vai ficar.

Angela: E você vai aproveitando isso, os talentos, os recursos de cada um...

S2: Claro! Então, tem sido um momento muito importante. Com relação às crianças, seja de qual faixa etária forem, então a gente pega, a gente mede, a gente fala da dieta alimentar, a gente procura estimular muito a amamentação, que é uma coisa forte aqui também. A gente tem mandado, ao longo destes anos, os agentes comunitários fazerem esses cursos de amamentação, e eles estão craques em orientar a amamentação! Todos que trabalham comigo - só a que foi contratada ultimamente que ainda não foi, não deu tempo - todos da minha equipe já fizeram curso de amamentação, vários de outras equipes já fizeram também.

Angela: Quando você fala 'nós', de quem você fala? Quem são?

S2: Como assim?

Angela: Sim, você fala em 'nós', só que você está começando a ganhar adesão agora...

S2: Sim, tô ganhando adesão dos colegas agora, mas a minha equipe aderiu desde quando eu cheguei aqui e trouxe a experiência do grupo que eles começaram comigo, [meus] agentes comunitários, auxiliares de enfermagem, eles participam disso.

Angela: Então é você com os seus agentes e auxiliares de enfermagem? 
S2: Agentes, auxiliares e a médica, que já é a terceira médica da equipe. Essa não está participando porque são só quatro horas, é uma médica de 20 horas, mas ela incentiva as grávidas a irem.

Angela: Então, você coordena esse grupo e conta com o apoio de uma agente, por exemplo?

S2: Todo grupo tem um agente junto, sempre tem. Agora tem uma agente comunitária minha que não quer mais sair, e a gente tem que rodiziar. Esse mês, nos quatro encontros o mesmo agente fica: ajuda a preparar o lanche, ajuda na hora de mostrar a técnica correta da amamentação, ele mostra. Eu trago a filha da minha filha (referindo-se à boneca da filha), que é minha netinha (risos), e eles mostram. Tem toda uma dedicação pra esse grupo. É um ritual mesmo. Trago meu porta-malas cheio de coisas: computador, TV, música, boneca, as coisas que a gente providencia e que agora as outras equipes estão contribuindo financeiramente para esse lanchinho, mas antes era a gente mesmo que providenciava - eu trazia e elas preparavam, né? Então, tem toda uma participação mesmo, elas estão envolvidas nisso, de uma forma muito intensa.

Angela: Entendi, perfeitamente bem.

S2: E com relação aos outros grupos de criança, a gente também faz toda essa questão do olhar biológico - nos meus grupos a gente tem isso muito forte - e sempre procura estar focando também a questão das relações, do afeto. Então, eu não quero só saber como é que come, eu quero saber como está na escola, é com este pensamento que a gente acaba descobrindo o trabalho infantil, os relatos que algumas mães trazem de como o filho está sendo tratado na escola. Então, porque a gente procura ter esse olhar ampliado - é deste olhar ampliado que eu falava pra eles no curso - assim, quando você entra numa casa, o que você vai olhar? Então, quem tinha passado pelo 'Janelas' e teve incentivo para esse olhar, trazia coisas, nossa, você ia adorar ouvir o que é o olhar deles! Você ia amar! Eu lembrava muito de você. Quem não tinha, a gente foi trabalhando isso, tanto é que se você perguntar pros agentes que fizeram esse curso, pra essa turma da gente, eles vão falar, eles falam na reunião: _'Hoje a gente tem um outro olhar na visita [domiciliar]'.

Angela: E que é ampliado por essa dimensão do vínculo, do afetivo. Haveria alguma outra dimensão que você identifica?

S2: Do vinculo, do afetivo, do respeito à cultura de cada pessoa, de que é diferente você estar aqui pra apoiar o desenvolvimento das pessoas, apoiar 0 empoderamento das pessoas. Você está aqui pra isso: apoiar, você pode apoiar através das suas orientações, apoiar de várias formas, mas que nós não estamos aqui pra criticar nem pra julgar. Então, isso faz a diferença do olhar. Eu acho que se você tivesse a oportunidade de ver isso, você vai ver a diferença, [vai ver] como eles pensam e têm realmente uma sensibilidade pra isso.

Angela: É muito bom saber que tem esse grupo aqui... 
S2: E aqui tem sempre essa questão mesmo, do vínculo, do respeito, do apoio ao desenvolvimento, do apoio pra que cada um assuma sua responsabilidade, que eles percebam a responsabilidade deles para com eles, para com os filhos.

Angela: Essa sua prática com as gestantes seria a sua prática educativa mais importante?

S2. Antes disso, eu só queria completar pra você - que eu não disse antes - que essas mulheres que participam do grupo de gestantes, que trazem seus medos, suas angustias, suas decepções, seus sofrimentos, e que têm espaço pra dividir, que são acolhidas, e que ao mesmo tempo têm a oportunidade de estar recebendo orientações, conhecimentos diferentes, de estar se preparando pra ir à maternidade, que conseguem perceber que se preparar pra ter um filho não é só ter um enxoval, ou a fralda, que a responsabilidade é muito maior do que isso. $E$ quando você vai fazer a visita do recém nascido, que é a primeira consulta, aí é muito bom, porque as que vêm no grupo, as que fizeram o pré-natal com você - eu digo comigo assim, [quero dizer] no posto de saúde e que participaram do grupo têm uma outra relação com o bebê, tem uma outra relação com as dificuldades dos primeiros dias do bebê - porque a gente sabe que tem sim, que é muito difícil os primeiros meses do bebê, a chegada desse bebê em casa, elas ainda estão desgastadas com tantas coisas, o parto, etc, mas elas lidam de uma outra forma com isso. Eu quero criar um instrumento, eu preciso arrumar um instrumento pra registrar isso. $E$ as grávidas que a gente vai [visitar] - assim que a criança nasce, a gente vai fazer a primeira consulta, é o enfermeiro que faz em casa [visita domiciliar], tanto pra puérpera quanto pra criança, em torno do sétimo dia ou dois, três dias a mais, dependendo do dia que [ela] tem o bebê - é nítido [identificar quem fez o grupo e o pré-natal na UBS] e aquelas que não participaram do grupo, aquelas que não fizeram o pré-natal com você, porque a gente vai fazer visita de qualquer recém-nascido, mesmo que tenha feito o pré natal pelo convenio, mesmo que tenha feito o pré natal em outro lugar e mudado agora, nasceu, tá na nossa área, nós vamos ver!

Angela: Identificando o que você não encontra nelas, talvez fique mais claro saber...

S2: Fica muito clara a contribuição que o grupo traz. As ansiedades, as dificuldades de lidar com esse momento que exige tanto da mãe, os próprios cuidados práticos com o bebê, com o umbigo, com a amamentação. Normalmente a amamentação já está correndo risco, porque a pega está errada, porque a família já tá lá com a lata do NAN, e ela não está preparada, não teve esse apoio, não teve essa reflexão com relação à amamentação. Tem um dia [no grupo] que a gente fala só de amamentação, a gente mostra a mama, como produz o leite, como é a pega, faz uma reflexão do que é mais fácil, amamentar ou dar mamadeira? E a gente não pode ser ingênua de achar que amamentar é mais fácil, não é mais fácil, mamadeira qualquer um dá, em cinco minutos, e a criança mama. A gente faz essa reflexão, porque pra você iniciar a amamentação você 
precisa ter essa consciência, você vai fazer uma escolha, de uma coisa que vai exigir dedicação, não é?

Angela: Por estarem mais bem preparadas, do ponto de vista emocional e da informação, pra lidarem com mais tranqüilidade, elas agüentam melhor, quer dizer, maior tranqüilidade, maior possibilidade de lidar com as dificuldades, é isso?

S2: Sim, criança mais bem cuidada, filho mais bem cuidado. Dessas que participam do grupo, poucas, raras têm problema com a mama. Aquela que não amamenta, não amamenta porque não é uma escolha dela, não adianta, você não vai sensibilizar $100 \%$. Mas a gente está vendo que essas que vêm no grupo nós estamos conseguindo sensibilizar e ajudar a fortalecer pra esse ato de amamentação.

Angela: E aí vem toda essa sua satisfação, por esse retorno pra você!

S2: Tem toda essa satisfação, e não dá pra deixar de fazer o grupo, porque o grupo é muito importante. Eu até deixo de fazer outras atividades que o PSF exige de mim, tem mês que as minhas visitas na área estão mais baixas, porque eu fico aqui dentro fazendo o grupo de gestante, porque eu valorizo muito isso. Mães melhor preparadas, (risos) filhos melhores...

Angela: Mais resilientes, mais fortalecidos... (risos)

S2: Mais resilientes, exatamente! É por isso que eu valorizo muito.

Angela: Você começou me contando que tem esse interesse, que isso já é teu, que vem com você desde a sua formação na Universidade, uma motivação desde a sua formação inicial, essa coisa com esse período...

S2: ...esse período, com a grávida, com a criança.

Angela: Pensando nas suas experiências de formação, não só de cursos que você recebeu, como também de cursos que você deu, como esse do módulo de formação dos agentes... Depois do 'Janelas', fale-me de outras experiências que você teve como educadora e como educanda, de cursos que marcaram você, que você acha importantes.

S2: O próprio 'Janelas', ter tido a oportunidade de passar por aquela formação foi muito importante. Eu comecei no 'Janelas' desde aquelas primeiras reuniões. Eu vi, não sei se no Diário Oficial, eu me inscrevi, eram reuniões sobre a cartilha...

Angela: Você era do grupo que construiu...

S2: Eu fazia parte. Não, não construí, eu ia nas reuniões, fiz alguns workshops foi em hotel, lembro que tinha almoço - e eu participava, eu sabia o que tava acontecendo, tinha esses grupos de discussão, tinha grupos de trabalho e a gente ficava o dia inteiro, opinava, então eu comecei a participar da questão do 'Janelas' 
daquela vez que eu vi, não lembro como foi a divulgação, eu me interessei demais e fui atrás. Por isso que fui ser multiplicadora.

Angela: Então você é mais antiga do que eu, sabia? (risos)

S2: Sou mais antiga que você. (risos)

Angela: Porque eu comecei no 'Janelas' depois. Das oficinas anteriores, das quais você participou, eu não participava, era a Iracema, lembra da Iracema? Médica da Monte Azul? Foi ela que me cooptou (risos), ela que me puxou pro 'Janelas'.

S2: Então, eu sou daquele tempo! Ah, era muito bom, era um alimento, aquilo pra mim era muito bom, porque na minha vida eu sempre amei criança, eu nasci gostando de criança, assim, é uma coisa inata, né? (risos). Aí, meus filhos, por conta disso, e por conta de eu querer uma coisa diferenciada pros meus filhos, eles estudaram em Escola Waldorf.

Angela: Ah, você tem também esse pezinho na Antroposofia...

S2: Agora a minha filha não está mais, mas os meus dois filhos mais velhos fizeram até o nono ano na Escola Waldorf. Eu fui uma mãe Waldorf por 15 anos, lendo, procurando aprender, trazendo o carrilhão da noite - às vezes eu trago pra ela o carrilhão da noite. Conhece o carrilhão da noite?

Angela: Não, porque eu não sou 'Mãe Waldorf'...

S2: Quem não é mãe Waldorf desconhece.

(Risos, gargalhadas)

S2: O pediatra dos meus filhos é antroposófico. Minha irmã é apaixonada por isso; eu conheci a Antroposofia pela minha irmã. Depois, depois conheci a Aliança pela Infância. Fui a alguns encontros da Aliança pela Infância. Porque não tem jeito, não dá pra separar, não é? Não dá pra você ser um profissional daquilo e não ser aquilo. Você é uma coisa só, não é? Então, eu acho que até levei minha irmã num dos encontros do 'Janelas', até dei a cartilhinha pra ela, porque a gente recebeu a primeira cartilha lá. Numa das oficinas, foi aquele senhor da UNICEF, apresentar tudo aquilo pra gente,

Angela: Foram parcerias que deram muito certo, PSF da Secretaria, Pastoral, Monte Azul, UNICEF, CREN, com quem a gente aprende muito...

S2: Muito, como a gente aprende!

Angela: E como ficou claro que o 'Janelas' fez um grande sentido na sua vida, contribuindo pra, como você disse inicialmente, legitimar, te autorizar...

S2: Legitimar, pra me autorizar, pra organizar, pra alimentar, trazer novos conhecimentos, pra fortalecer, lógico, a gente aprende muito, né? 
Angela: E em relação a outros cursos, afora o 'Janelas'?

S2: Essa capacitação que eu fiz, que foi uma capacitação pedagógica pra gente dar o curso técnico pros agentes comunitários. Outro curso que a gente faz aqui na zona norte, de Saúde Reprodutiva, que quem começou - foi fundador disso - foi o Dr. Nilson, que agora não está mais. É um curso voltado pra atenção educativa na saúde reprodutiva, trazendo um preparo e um olhar diferenciado para o trabalho com grupos de gestantes, planejamento familiar, puerpério. Este grupo foi de três anos, duas vezes por mês, que também trouxe uma contribuição importante.

Angela: Mas você estava no papel de facilitadora, de educadora? Coordenando?

S2: Não, não, recebendo.

Angela: Ah, recebendo, como educanda.

S2: Como educanda. De lá pra cá, a gente fez a multiplicação do 'Janelas', deu o curso dos agentes. Sempre que a gente tem oportunidade, dá o curso pros auxiliares, pros agentes, nada muito oficial, mas a gente faz um pouco.

Angela: Você quer dizer que continua fazendo formação com eles? É isso?

S2: Sim. Só que é uma coisa mais intensa. [intensiva?]

Angela: Seria educação permanente?

S2: Sim. Às vezes, você não consegue formatar isso assim. Mas, você...

Angela: Quer dizer que, no seu cotidiano de trabalho, você continua cuidando de formá-los. É isso?

S2: Sim. Também teve umas oficinas que nós participamos - depois nós tivemos que vir e fazer um trabalho com os agentes comunitários - que foram oficinas que a Associação Saúde da Família fez com a gente. Enfim, a gente sempre está envolvida nisso.

Angela: Pronto, acho que concluímos. Muito obrigada!

S2: Concluímos? Muito bom falar sobre tudo isso, viu? 
Entrevista no 3 realizada em 05.06.2009 (duração: 42 minutos) Local: na Unidade de Saúde

Angela: no campo das suas práticas de educação em saúde, o que mudou em você do 'Janelas' pra cá? E o que não mudou, porque você já fazia e que, portanto, já era seu?

S3: Eu entrei no PSF em 2001. Então, a gente teve treinamentos sobre os ciclos de vida, a gente foi capacitado pra ser, como se fala? Assim, eu sou enfermeira, e tem o médico, e nós somos generalistas, e a gente atende todo o ciclo de vida - criança, gestante, hipertenso, diabético, idoso e adolescente - a gente, com o nosso treinamento, vinha fazendo o normal, quando teve o 'Janelas de Oportunidades', que foi um projeto que a gente se envolveu bastante, e assim, além de se envolver bastante, a gente aprendeu muita coisa, que é aquela questão da atenção direcionada para aquela faixa de vida, aquele período de vida onde está formando as sinapses! Então isso, não só para mim, mas quando eu multipliquei, eu senti que isso despertou muito nos profissionais [também]. Então, para mim acrescentou - eu acho que a pergunta é essa: o que acrescentou - pra mim acrescentou enquanto informação, enquanto prática, enquanto valorização de uma situação de uma criança que a mãe, ou outras pessoas, julgam que ela está sendo mal educada, mas a gente sempre fala assim, que ela não é mal educada, que ela mexe em tudo porque está explorando o mundo. Isso é uma coisa que ficou muito pra gente, para o profissional multiplicador, e ficou também pras pessoas pra quem nós passamos. Hoje, pra você ter uma idéia, eu falo ainda nas consultas e eu tenho agentes comunitários que até hoje distribuem cartilhas. Eu ainda tenho a cartilha! Tenho! Tenho a cartilha sim!

Angela: Você ainda tem cartilhas para distribuir paras as famílias ou apenas para trabalhar aqui dentro, com os grupos, por exemplo? (surpresa)

S3: Tenho pra distribuir e pra trabalhar! Nossa, eu guardo com muita [sentido de controle e parcimônia], tenho cartilhas e tenho cadernos também!

Angela: Então você vai me arrumar uma! (risos) Quantas cartilhas você tem ainda?

S3: Cartilha eu não tenho muita não, porque eu controlo, porque quando a família é muito necessitada ou a pessoa vem me pedir eu acabo fornecendo. Tenho também aqueles joguinhos que eu fui buscar no Monte Azul, que são aqueles livretos que vão de 1 a 17 [kit de folders da coleção 'Vencendo a Desnutrição' do CREN]. Hoje eu faço grupo de gestante toda terça feira e eu falo da importância do desenvolvimento, da questão do afeto, do vínculo, da resiliência, eu falo de tudo! 
Angela: Então, você está focalizando a informação, aquela questão do desenvolvimento do cérebro...

S3: O estímulo, o quanto o estímulo é importante!

Angela: O quanto é importante a família estar com a criança, e o que mais? O que mais você recebeu que você não tinha, enquanto conhecimento ou prática?

S3: O estímulo, que a criança aprende vendo, ela copia, imita o adulto, não é assim? Da responsabilidade que a gente tem enquanto formação, enquanto formador de opinião, não só dos profissionais, mas das mães também, dos cuidadores enfim. Eu acho que é isso.

Angela: E no seu jeito de...

S3: Falar?

Angela: de lidar com as pessoas, falar, você percebeu alguma mudança importante?

S3: Eu acho que teve uma mudança em toda a vida da gente, sabia? Eu me lembro muito bem de quando a gente foi multiplicar, inclusive o pessoal do Pólo de Capacitação que falava assim:_'Meu Deus, se eu tivesse que criar meus filhos hoje, olha o quanto eu estou aprendendo'. Quantas informações que até então não eram praticadas, não eram passadas, que elas estavam sabendo naquele momento, mas as filhas já estavam moças. Então a gente falava assim: _'Mas isso é bom porque vai servir para os seus netos, vai servir porque você é um educador, porque quem trabalha na saúde é um educador eterno, né? A gente é um educador e essas informações vão servir pra gente mesmo como experiência profissional. Eu acho que é muito bacana isso.

Angela: Conte-me um pouco mais sobre essas suas práticas, como educadora.

S3: Na prática é assim: no momento das consultas a gente tá sempre falando o quanto é importante [a estimulação], a gente avalia a questão daquela criança que é pouco estimulada - você consegue visualizar se a criança é pouco estimulada, se a criança não responde - depois que ela passa quinze, vinte minutos com você, com você estimulando e aí ela passa a responder, então você observa que essa criança não é tão estimulada quanto deveria. A gente percebe também que não são todos os profissionais que têm essas informações. 
Angela: Quer dizer que mudou a sua percepção sobre o desenvolvimento da criança?

S3: Muito!

Angela: Não é mais só medir e pesar!

S3: Não. Não é só medir e pesar. A mãe tem mania de chegar e sentar o filho no colo e querer segurar ele pra ele [não mexer em nada]. Eu falo: 'Mãe, vamos conversar, deixa ele que eu vou observando o que ele está fazendo enquanto estou conversando com você'. Então, a gente escreve no relatório 'criança explora o mundo com facilidade'. Aí ela fala: _'Filho, não mexe aí'. Eu digo pra deixar ele, que quando for para ele não mexer eu falo, que aqui quem estimula sou eu, porque eu quero ver como ele reage. Se o meu filho é mexelão, ele não pode mexer em tudo, aí vem a questão do limite, eu trabalho muito a questão do limite, mesmo quando você fala da questão da alimentação. A mãe chega para você e fala assim: _'Ah, meu filho come tão mal!' 'É mesmo? O que ele come? E a gente sempre fala do aleitamento, da importância da refeição. A mãe: _'Ele come muita bolacha, salgadinho' E a gente pergunta: _Quem é que vai ao supermercado?' (risos). Então a gente puxa pra aquela coisa da consciência da mãe. Outra coisa: _'Olha mãe, você vai escovar os dentes do seu filho, mostra pra ele fazendo, porque ele aprende imitando, ele imita o adulto'. Aquelas coisas que não apagaram da mente da gente.

Angela: Você incorporou na sua prática de atendimento.

S3: Totalmente! Foi um crescimento muito grande. Em compensação, eu vejo o despreparo das mães com relação a isso, não sei que futuro a gente vai ter com esses jovens. Eu vejo hoje que meus filhos, claro, eles têm dezoito anos, mas desde pequenos eles terminam de almoçar e vão escovar os dentes. A questão de ensinar, você não precisa ficar toda hora repetindo, você ensinou e ele aprendeu e ele pratica. Algumas coisinhas você vai só aparando as arestas, mas o ensinar está muito empobrecido, muito.

Angela: Tem muito trabalho pela frente.

S3: É, e a gente trabalha com uma população carente, eles são carentes de tudo. São carentes de informação, de educação, de espírito, de tudo que você possa imaginar. E você fala isso para mãe e ela fala: _'Ah, é mesmo?'. E a gente diz: 'A senhora deveria ficar preocupada se 0 seu filho fosse assim o tempo todo, estático!' [parado, passivo]. A questão da prevenção então, dependendo da idade, a gente fala de acidente doméstico, que ele vai explorar, ele não vai ter noção do que ele está fazendo. É muito bacana! 
Angela: O que mais você poderia me contar sobre suas práticas? Quais características já eram suas e quais você foi desenvolvendo a partir do 'Janelas'?

S3: Que eu fui desenvolvendo a partir do 'Janelas', características minhas?

Angela: De outros aprendizados também, que você vem incorporando nestes últimos quatro anos.

S3: Eu acho assim, que o 'Janelas' serviu para que eu multiplicasse, para que eu aplicasse e para que eu aprendesse também. Essa questão do incorporar, ele serve como ensinamento pra você mesmo, porque você muda o seu conceito de vida. Eu cheguei a ir naquele encontro sobre infância, que esteve até um pessoal do Japão, lembra que teve aquela apresentação? Acho que você chegou a ir. Teve uma fala muito legal sobre a união da educação com a saúde. Isso não acontece. Hoje em dia eu estou indo numa escola para fazer justamente essa prática de saúde e educação, porque a gente precisa unir [as duas]. Quando eu passo a informação relacionada à saúde ali dentro, eles aprendem muito mais; e quando é o professor, eles aprendem muito mais ainda. Assim, eu não sei se estou conseguindo responder exatamente o que você quer. Em termos dessas práticas, eu pratico dia a dia.

Angela: Na consulta, nos grupos...

S3: Na consulta, nos grupos, na minha vida pessoal, eu pratico. Você está entendendo?

Angela: Estou entendendo que houve uma grande ampliação da sua visão sobre o desenvolvimento da criança.

S3: Sim, muito e o quanto isso é importante. Tem gente que fala assim: 'Ah, ele vai crescer mesmo assim, então vai crescendo que nem um bichinho, né?'. Não é bem assim não. Nós temos características diferentes [dos animais], a gente precisa ser estimulada. Se ele cresce numa selva, ele vai agir como um bichinho da selva; se ele não é estimulado, não vai aprender, e o dano que ele tem... Outra coisa que a gente fala: se bem estimulado, a projeção lá na frente é muito importante. Tem estudos que falam que bebes que mamam no peito têm mais facilidade de passar em um concurso. Isso para uma mãe, nossa! [marca, impressiona].

Angela: Qual seria a reação dela?

S3: [ela diz] Nossa, eu não sabia que isso tinha tanta importância!

Eu falo: _'Gente, quando você troca afeto com seu filho, olha o que você está passando, segurança, amor, carinho, proteção, alimentação, conforto. Olha o que 
você está criando, olha a responsabilidade que você tem enquanto responsável pela procriação da espécie, né?'. Eu gosto tanto de falar isso, e isso tem uma repercussão muito boa para elas. Eu faço grupo de gestantes, de adolescentes. $E$ toda a oportunidade que a gente tem pra estar reforçando essa questão do 'Janelas', do estímulo...

Angela: Grupo de adolescentes grávidas?

S3: Não, no geral. Grupos com foco na prevenção de DSTs e AIDS e nas fases do desenvolvimento, a importância do cuidado, o processo de prevenção de acidentes, a responsabilidade. Outro dia eu estava lendo ' $O$ Nó do Afeto' [conteúdo da cartilha]. Eu estava lendo para uma agente comunitária que tava preocupada com o filho, com o tempo dela com o filho. Eu disse assim: _Você não fica preocupada com o tempo que você dá para ele, fique preocupada com a qualidade do tempo que você dá pra ele'. Aí ela achou maravilhoso e eu dei a cartilha pra ela. A gente tem aquela noção errada, que sai o dia inteiro, o filho fica doente e você se sente péssima, ai meu Deus, eu sou culpada, o que eu fiz de errado? E, na realidade, não é bem assim, se você entender a modernidade, que você tem que trabalhar, se você conseguir simplificar, não transformar isso em sofrimento. Então, pronto. Ou você vai ao psicólogo pra conseguir entender essas coisas (risos).

Angela: Encontrei com sua ex-gerente em uma oficina que eu estava fazendo para o UNICEF. Como se trata de outro material, mas com o mesmo foco, a mesma proposta, ela relacionou com o 'Janelas' e trouxe um pouco da dimensão da implantação aqui, nesta Unidade, de como ela apoiou você...

S3: Foi muito bacana! A gente só consegue tocar em frente quando a gente tem apoio. Graças a Deus foi assim, uma coisa envolvente, que envolveu todo mundo, foi muito bom.

Angela: Atualmente, o que existe aqui, além das tuas práticas nas consultas, nos grupos, nas conversas com os agentes?

S3: Olha, não é todo mundo que conhece o projeto. O projeto teve um tempo de vida, infelizmente. Entraram outros profissionais, naturalmente. Hoje a gente tem um grupo de aleitamento, muito bonito, que é feito todas as quintas feiras, onde a gente trabalha com o incentivo ao aleitamento materno exclusivo até seis meses de idade. Agora, a gente vai colocar para a criança. Nós temos um grupo de profissionais do NASF [Núcleo de Apoio à estratégia Saúde da Família], tem um educador físico que trabalha com crianças, para tirar da rua, ele tem aquela preocupação. Quando eu montei grupos fixos com os meus agentes comunitários, a gente discutiu a idéia e a idéia foi pra frente: tinha uma agente comunitária que toda semana tinha um encontro com crianças para contar histórias, pular corda, fazer alguma coisa nesse 
sentido. Assim, individualmente, alguma coisinha a gente sempre acaba fazendo, mantendo, mantendo práticas com os agentes.

Angela: Sim, e com as outras equipes também?

S3: Saíram quase todos que fizeram multiplicação aqui. Eu não sei se essa enfermeira que faz o aleitamento, eu acho que ela não conhece o 'Janelas' também. Não teve aquela retomada, não teve reciclagem; ah, a gente não fala reciclagem porque material que é reciclável, né? (risos).

Angela: Digamos que não houve aquela atualização, pronto! (risos)

S3: É, não houve atualização. Acho que por conta mesmo do projeto não ter tido continuidade, acho que se tivesse, com certeza teria tido uma atualização.

Angela: Seria uma injeção de ânimo, com certeza. Mais cartilhas, novos materiais...

\section{S3: Com certeza!}

Angela: De todas essas práticas, qual foi a mais importante, a mais significativa pra você, seja de formação de equipes, seja de atendimento de famílias.

S3: Eu acho que a coisa que mais ficou foi quando nós multiplicamos, foi uma coisa de acordar leões, sabe aquela coisa de leão adormecido?

Angela: Fale mais sobre isso, conte em detalhes.

S3: Então, não sei se você lembra, eu acho que ficou cada enfermeira de cada unidade responsável pela multiplicação dos profissionais internos, cada uma da sua unidade. As Supervisoras eram as cabeças, e são nossas supervisoras até hoje. O movimento interno, eu me envolvi muito com o projeto, compramos coisas, fomos buscar as cartilhas, montamos materiais, dividimos os profissionais, foi uma coisa tão forte que o pessoal do Pólo de Capacitação quis vir participar comigo, e eles vieram, e falavam assim: _Mas, peraí, que negócio é esse, que projeto é esse?'. Quem deveria multiplicar eram eles. Eu virei uma garota propaganda; aonde eu ia, eu falava do 'Janelas': _'Gente, é um projeto maravilhoso, eu passava assim pra eles'. E eu coloquei eles em um dos grupos.

Angela: Então, com um reforço da Supervisão foi feita a multiplicação para todas as equipes desta unidade? 
S3: Na verdade eu auxiliava, montava tudo. E elas, a gente vinha e dividia temas e aplicava os temas, fazia as dinâmicas, naquele esquema que você passou pra gente.

Angela: Isso eu queria lembrar. Não faz pouco tempo, faz quatro anos!

S3: Quatro anos, mas que se você não pratica, você perde, sabia? Não adianta você fazer uma coisa e deixar.

Angela: $O$ que você me diz é que tem praticado e está rememorando algo que foi muito marcante pra você, da própria multiplicação, ou seja, você estava junto com as duas. E o pessoal do Pólo de Capacitação?

S3: Eu acho que deve ter somado muito. A própria - vou lembrar no nome dela - ela falou: _'Meu Deus, se eu soubesse de tudo isso quando eu criei minhas filhas, eu não cometeria os erros que cometi!'. Porque a gente comete erros, por mais que a mãe não queira, eu falo pra mãe, não se penalize, você não sabia, porque a gente peca por ignorância. Agora, não procurar saber, aí é grave.

Angela: Quantas pessoas foram envolvidas na multiplicação? Vocês fizeram mais de uma oficina?

S3: Foram dois grupos, foram duas etapas. Olha, aqui na unidade nós temos quase cem funcionários.

Angela: E qual foi a carga horária?

S3: Eu fiz dois dias, dois dias e meio, uma coisa assim, deu vinte horas! Agora, não sei se vale a pena comentar, nós tivemos muitas dificuldades com aquele papel que a gente tinha...

Angela: A ficha de acompanhamento?

S3: Isso. Dá muito trabalho! Até hoje a gente tem muita dificuldade, porque o enfermeiro é preenchedor mesmo; agora, médico, porque ele tem um volume muito grande de consultas, e pra eles era muito difícil.

Angela: Acho que aquela ficha não foi bem trabalhada, na minha opinião...

S3: A ficha foi difícil. Eu acho que não é nem questão de ser bem trabalhada; eu acho que a questão é do volume de coisas de rotina. Hoje em dia eu vejo, pra você instituir um instrumento de avaliação, você tem que fazer uma coisa prática, ela não era prática. 
Angela: Você sabe por que eu acho que não foi bem trabalhada por nós? Pelo seguinte: ela é extensa sim, mas na verdade ela não é nem para avaliar, ela é para ajudar o profissional a olhar o que você tá me contando que olha; e que, se o que deve ser olhado for olhado, ela pode ser dispensada, ele não vai precisar mais dela. Hoje, eu acho que a gente deveria fazer uma revisão dessa ficha, no sentido de que ela entre de um outro jeito, porque ela entrou dum jeito complicado.

S3: Eu acho. Entrou de um jeito complicado, a gente tinha pouco tempo de programa, foi difícil.

Angela: Difícil, e suponho, muito pouco usada.

S3: É assim: a intenção do projeto, a idéia do projeto, ela ficou até hoje; a ficha, ela ficou muito pouco tempo, porque ela era trabalhosa.

Angela: E os manuais?

S3: Outro dia eu estava olhando o manual. Porque vira e mexe você precisa ir buscar, espera, deixa eu dar uma olhadinha [no manual de apoio].

Angela: Dos seus agentes, da sua equipe atual, quantos são daquela época?

S3: Dois agentes. Tem equipe que não tem mais ninguém. Da equipe 1 , não tem ninguém; da equipe 2, tem uma pessoa; da equipe 3 , que é a minha, tem duas; da equipe 4, não tem ninguém; da equipe 5 , não tem ninguém. Então, teria que começar tudo de novo para essas pessoas.

Angela: Mas dessas pessoas que estão aqui, quem utiliza de alguma forma esse material? Ou é só você que está usando?

S3: O agente comunitário, eu acho que usa, usa em termos do conhecimento, da passagem da informação; ele não usa a ficha, mas usa o crescimento: _Mãe, essa criança fica muito no chiqueirinho; Mãe, dá objetos quentes, frios, redondos, quadrados'. Você entendeu? Isso ficou, mas os instrumentos não. Ficou aqui dentro. Nós tivemos uma janela preenchida... (risos).

Angela: ...pela conversa (risos). Isso que você está me falando confirma o que a gente discute muito lá na escola [EEUSP]: a incorporação na própria prática, na própria percepção e concepção do trabalho...

S3: Do valor, da importância... 
Angela: E aí é como você diz, não precisa de instrumento, não precisa de ficha.

S3: Não precisa de instrumento. Não precisa da ficha. Tinha uma agente comunitária, até o mês retrasado, que ela ainda saía com as cartilhinhas, e as meninas me falavam: _'Até hoje ela fala do 'Janelas'. Quem vivenciou, quem incorporou, fala e vai continuar falando. Tem uma auxiliar de enfermagem aqui que é maravilhada pelo 'Janelas', que fala dele até hoje. São coisas que vieram, que a gente passou, e eu acho que a gente passou de uma forma boa, porque senão não ficaria. Não sei qual a experiência que você tem de outros lugares, porque aqui foi muito legal, a gente vivenciou uma época de aprendizado, muito produtiva.

Angela: Foi um processo forte.

S3: Acho que a minha ex-gerente deve ter falado sobre isso, né?

Angela: E ela retomou. Quando eu estava trabalhando essa capacitação com o material do UNICEF, ela falou: _Nossa, tudo isso que você está falando me lembra o 'Janelas', eu vi no 'Janelas'! Foi assim que eu identifiquei que ela era a sua gerente.

S3: Legal, legal mesmo.

Angela: De quais outras experiências de formação, depois do 'Janelas', você participou? De lá pra cá, você participou de alguma outra capacitação, seja como educanda, seja como educadora?

S3: Olha, a gente participou de um treinamento voltado pra alimentação - eu acho que também está relacionado - em que a gente trabalha com a criança, principalmente a criança de periferia, com aquela questão da valorização da importância do alimento. Pra elas, 'danoninho que vale por um bifinho' é melhor do que aquela comidinha que ela faz para o filho dela. Pra ela! Porque pra gente não é. Você sabe que não é. Não é mesmo. Não teve mais cursos não, depois daquela época, deu uma parada.

Angela: Uma parada boa, então. Teve o 'Janelas'...

S3: E o curso de aleitamento. Foram duas situações relacionadas com alimentação. A de aleitamento, que foi muito boa, foi dada pela Camila, que trabalha para o Ministério da Saúde; e essa do CREN, as meninas que estão aqui agora, do CREN - Leste.

Angela: O CREN é um parceiro importante do 'Janelas'. 
S3: Quando o CREN era só na Vila Mariana, era muito longe. A gente tem as fitas também.

Angela: Tem aquela série de books 'Vencendo a Desnutrição', as fitas, e aqueles folders que você falou no começo.

Aos 31 minutos de entrevista, entra uma enfermeira que vem pedir ajuda técnica. Está ansiosa e precisa discutir um caso, urgente. Diagnóstico: Dermatite de inverno. [interrupção de 4 minutos]

Angela: Retomando pra gente concluir: você estava me falando de outros cursos, outras experiências de formação que você teria feito, como educanda ou como educadora, do 'Janelas' pra cá. Foram dois cursos, um de amamentação e outro de alimentação.

S3: Chamava 'Manejo clínico do aleitamento'.

Angela: O que, nesses cursos, foi interessante, te chamou a atenção?

S3: Sobre alimentação, a gente tem que praticar mesmo. Sobre aleitamento, a gente segue orientação do Ministério da Saúde e do UNICEF.

Angela: O CREN é uma referência aqui.

S3: Hoje é. Naquela época não era não. Hoje ele é e dá suporte. Se a gente precisar eles vem. Se a gente precisar, a gente encaminha, eles acolhem. Tranqüilo.

Angela: Além dos conteúdos dessas capacitações, teria alguma qualidade ou dificuldade que você poderia ressaltar?

S3: Dificuldade? Seria você falar que tem que enfrentar a realidade, não adianta falar... Uma coisa é falar pra uma mãe sobre a valorização dos alimentos, o reaproveitamento alimentar, o estado das coisas que são jogadas fora, que ela vai entender; e pra uma mãe pobre que diz: _'Mas, é muita humilhação utilizar o que os outros jogaram fora'. Além de tudo isso tem o convencimento, a coisa da auto-estima. Eu não jogo o talo, mas é outra história.

Angela: Mas esses conteúdos foram trabalhados de alguma outra forma especial? 
S3: Não. Esses conteúdos a gente já tem, mas eu falo como dificuldade, porque a mãe fala assim: _'Eu não tenho como dar verdura para o meu filho'.

'Mas, mãe, vai lá, aquela folhas que eles jogam da couve, aqueles talos, ali é que estão os verdadeiros alimentos'. É mais uma coisa de formação mesmo, de valorização. É delicado. Tem mãe que fala assim: _'Eu não dei peito para os meus cinco filhos e eu não vou dar pra esse também!'. Tem muita coisa da educação mesmo, da formação do povo mesmo, daquilo que vem do berço, né?

Angela: E por que teve tão pouca capacitação nesse período?

S3: Porque não depende da gente, depende de verba. O nosso parceiro, apesar de ser bom parceiro, deu uma parada. A gente não se atualizou até hoje, depois daquela época, dos ciclos, dos momentos. A gente teve Momento I, Momento II.

Angela: E os agentes novos, como ficam? Não tem mais o Introdutório?

S3: Tem o Introdutório dentro do Momento I. Tem. Mas não dá pra abordar tanta coisa! Eu acho que não. E aí vai aprendendo no dia a dia, ouvindo falar. Quando a gente identifica alguma dificuldade - infelizmente a gente é mais voltada para as doenças mesmo, que tem as doenças sazonais, é dengue, é leptospirose, é gripe - e a gente trabalha em cima disso. A gente estava falando da questão da importância da alimentação, isso é discutido, por exemplo, no caso da obesidade, eu atendi uma menina de doze anos com oitenta quilos. Marcaram uma consulta comigo. _'Ah, vamos lá, o que você come quando levanta? Nada. E você acorda e não come nada e vai pra onde? Eu vou pra escola'. Como que uma pessoa, depois a gente aborda na parte final, como você vai aprender, se não está alimentada adequadamente? Uma coisa depende da outra. _'E aí chega o recreio e o que você come? Nada. Que horas que você vai comer? Uma, duas horas da tarde. E o que você vai comer? Salgadinho, bolacha, biscoito'. Ela come comida à noite; então ela passa o dia inteiro com o que a gente chama de besterol, infelizmente. Eu até marquei uma consulta pra ela no CREN. Então, é isso.

Angela: Então é isso, eu acho que a gente terminou! Obrigada! 
Entrevista no 4 realizada em 25.06.2009 (duração: 31 minutos) Local: na Coordenação do PSF

Angela: no campo das suas práticas educativas, o que mudou em você do 'Janelas' pra cá, e o que não mudou, porque você já tinha, porque você já fazia?

S4: No PSF, eu tinha começado há pouco tempo; então, a gente tinha algumas experiências do PSF, mas a sensibilização, acho que o importante do 'Janelas' é que ele foi um projeto de sensibilização, que eu aprendi tanto para a carreira profissional como para a vida pessoal, porque tem coisas do 'Janelas' que eu guardei pra minha vida pessoal por causa da criança. Lembra que falava do tempo? Eu não esqueço da cartilha, da história do 'Nó do Afeto'. Então, eu tentei passar pros agentes comunitários, para a equipe, a importância do cuidar, de estar ali junto com a criança, desde a gravidez até a idade de seis anos. E o nosso trabalho de multiplicação também foi muito bom, lembra? Nós fizemos junto com a Supervisora. Eu, ela, o enfermeiro V. e a enfermeira V. Fizemos numa carga horária menor, mas nós conseguimos fazer com os médicos, enfermeiros, agentes comunitários, nós conseguimos multiplicar.

Angela: Sim, você estava falando que o 'Janelas' funcionou muito como sensibilização pra tua vida e pro teu trabalho. Sensibilização especialmente em relação a que? A criança, esses cuidados, o tempo da atenção?

S4: Aquela cartilha é maravilhosa! Eu sempre tentei mostrar para o agente comunitário, sensibilizá-lo pra cuidar da família, [porque] aí é que a gente tem dificuldade, [pois] são seres humanos, cada um age de uma maneira, não tem como você mudar as pessoas, e por isso que foi sensibilização, [quer dizer] você tenta mudar, de alguma forma, a forma como ele trabalha. Então, a dificuldade maior que nós tivemos foi com as folhas, lembra das fichas? Então, a ficha não deu! Não deu certo porque a gente tinha muitos impressos, e eu tive problema com os médicos; nos atendimentos, a gente até tentava - existem ainda fichas dentro dos prontuários. É, tem fichas dentro dos prontuários! Eram preenchidas pelos médicos e pelos enfermeiros nas consultas.

Angela: Entendo que com dificuldade. Você conseguiu fazer com que isso andasse de alguma forma?

S4: Em algumas consultas sim! Aí nós tínhamos problema com a falta do impresso, e conseguimos colocar em algumas - não foram todas as crianças - nós priorizamos algumas famílias e aí fomos colocando. Tem prontuários de família que eu pego e tem o impresso lá.

Angela: Tá parado, mas tem um registro.

S4: Sim, tem um registro, que [prova que] nós trabalhamos com o projeto. Então, pra vida pessoal, profissional, a parte da vacinação que é importante, a parte do pré-natal mesmo - trabalhava-se aquela mulher desde o pré-natal, da criança que está chegando, aí a vacinação, depois os cuidados, os acidentes na infância. Hoje 
eu ainda falo, eu acho que aquele instrumento [a cartilha] é muito bom para o agente comunitário. Quando entra um agente comunitário novo, eu apresento a cartilha, dou uma cartilha pra ele - porque eu ainda tenho cartilhas guardadas peço para ler, para conhecer um pouco as fases da criança.

Angela: Então, de uma forma ou de outra, você continua tocando esse trabalho, não como foi inicialmente, mas continua...

S4: Sim. Isso, eu não me esqueci, tá vendo?

Angela: Eu queria entender melhor o que mudou pra você. Entendi que mudou nesse sentido de sensibilizar você para esses cuidados todos os quais a criança necessita, tanto com seus filhos quanto lá na unidade de saúde. Além desses conhecimentos, alguma outra coisa do 'Janelas' mexeu com você, marcou você? Esses cuidados são conhecimentos?

S4: Sim, são conhecimentos.

Angela: São informações importantes. Além disso, algum outro aspecto, você achou marcante pra sua vida pessoal/profissional?

S4: Ah, o que me marcou e fez parte da [minha] sensibilização pessoal, que foi a história do 'Nó do Afeto', tinha aquela parte do tempo, da família, de qual é a sua rede social: _Ah, faltou a sua farinha, e você vai pedir a sua farinha pra quem?'. Eu achei muito importante, interessante para a vida pessoal, porque você vai, realmente, rever isso na sua vida. Eu tinha, na época, só uma filha. Aí, eu me lembro que o que marcou muito foi o tempo. Eu chego, não tenho tempo, não tenho tempo pra isso, pra aquilo. $E$ a partir do 'Janelas', a vida pessoal que eu falei pra você que mudou, que me marcou, que me sensibilizou, é isso. Você pára pra refletir, eu ficava pensando: _Eu faço isso? Não, agora eu vou fazer isso'. E a partir do 'Janelas' eu aprendi que eu precisava parar um pouco pra minha filha; é um pouco da empatia, de você se por no lugar do outro. Eu comecei a fazer em casa: ela me chamava e eu parava e dava atenção, pra depois fazer [as outras coisas], ela queria brincar, porque antes eu não fazia isso. Então, eu acho que o 'Janelas', pra minha vida pessoal, marcou isso, Angela! Com certeza neste ponto!

Angela: E no trabalho foi nesse ponto também?

S4: Esse ponto também!

Angela: Então, como isso apareceu com os seus clientes, pacientes, com as familias?

S4: Nas consultas, aí que eu faço as perguntas, a entrevista, pra ver quem cuida, quem fica junto, quem brinca, qual é o vínculo mesmo. A gente tem muitos problemas na região, com os pais. Agora, eu estou com um problema, um caso sério de um bebê, que falta cuidado, ele foi pro hospital, tá com o conselho tutelar. Nisso é que eu tenho que transmitir pra família o cuidado que ela tem que ter com 
a criança. Que ser humano, que adulto ele vai ser? Depois, lembra da fita, da pedra, do cara jogando a pedra? Nossa, foi muito importante!

Angela: Fita? Pedra? Não me lembro...

S4: Era uma fita de vídeo que nós assistimos. Tinha um cara que [se tornou um] adulto, uma pessoa super revoltada, e aparece ele jogando pedras no lago; e a cada pedra que ele jogava no lago era um problema que ele tava tirando dele! Nossa, Angela, se eu conseguisse esse meu vídeo! Eu tenho lá na unidade...

Angela: Era um vídeo da Pastoral sobre violência contra a criança? Eu tenho uma cópia.

S4: Você tem??? Nossa aí você deixa aqui, pra copiar. Nós deixamos fitas aqui [Coordenação do PSF] pra copiar, só que essa saiu super mal. Nós usamos essa fita na multiplicação. Eu queria levar essa fita pra Unidade, mas não tinha vídeo, aí eu não consegui.

Angela: Eu arrumo uma cópia pra você, em DVD e tudo.

S4: Ah, Angela, não acredito! Nossa aquela fita é formidável! Então, quando nós usamos na multiplicação, nossa, o povo ficou assim [expressão de 'queixo caído', surpresa, forte impacto emocional].

Angela: Eu não sabia disso...

S4: Você viu como eu guardei?

Angela: Parece que é uma história de uma criança...

S4: De uma criança...

Angela: Aí aparece ele adulto, tem a ver com maus tratos...

S4: Você lembra? Ele comendo, o pai brigava, a mãe mentia que ia buscar ele na escola e deixava ele esperando. Depois, quando [a mãe] chegava em casa, ela falava: _É que esse moleque tava fazendo a lição e eu tenho que ficar esperando até tarde!'. E ela ficava passeando pela rua. E ele cresce um adulto revoltado. Aí é que hoje eu penso nas crianças que tem lá, vivem numa situação de miséria.

Angela: Me conta como é que vocês trabalharam esse vídeo na multiplicação.

S4: Na multiplicação, só. Eu queria trabalhar na unidade; se tiver, eu ainda vou usar, porque eu achei demais! Ela é muito tocante, né?

Angela: Você chegou a usar com a população?

S4: Não, só na multiplicação! Eu queria levar pra população. 
Angela: E como você pensa em fazer esse trabalho?

S4: Agora, nós estamos com o NASF [Núcleo de Apoio à estratégia Saúde da Família], que tem uma equipe com psicóloga, nutricionista, fisioterapeuta, e nós estamos trabalhando com grupos. Nós fizemos grupos de hiperatividade, grupo com as mães - às vezes, quem tem que mudar não é a criança, a criança tá aprendendo. Aprendendo como? Imitando, copiando! É assim que eu falo pras mães. Outro dia, em um grupo, [estávamos] eu e a psicóloga, [a mãe] falando de um menino de 12 anos - ela fala do menino, aquele [xingamento?], nossa, ela fala cada nome, do moleque! Aí nós falamos assim: 'Quem é o problema? É ela quem tem que mudar!'. A psicóloga diz que quem tem que mudar é ela, é o adulto, não adianta querer que a criança seja de uma maneira, se não trabalhar o adulto.

Angela: Você está pensando em usar esse material para trabalhar com as famílias sensibilizando-as para mudar o seu comportamento com as crianças.

S4: Então, por isso que eu te falei da importância dessa sensibilização. Nós temos problemas com drogas, com jovens e crianças que são envolvidos com drogas.

Angela: O que mudou muito você, que te marcou, que você lembra até hoje e trabalha com isso de alguma forma são esses cuidados todos que você...

S4: Pra formação, pra vida dele, da criança. O cuidado dessa criança agora, de que maneira essa sensibilização, pensando no futuro dessa criança, no adulto.

Angela: Então, você passa para as famílias sensibilizando-as através desse material, é isso?

S4: É. Nossa!

Angela: $E$ o que não mudou em você, que você já tinha, era o que você estava aprendendo com o PSF?

S4: Mas nós entramos crus, sem nenhuma experiência. O PSF tinha acabado de começar. Depois do 'Janelas', cursos assim nós não tivemos.

Angela: O que ficou do 'Janelas' permeia muito as suas práticas até hoje. E de outras práticas educativas nesse período, você teria alguma coisa para me contar?

[silêncio]

Angela: Não exatamente do 'Janelas', outras práticas de educação em saúde, especialmente com crianças, pequenas, gestantes...

S4: Ah, gestantes, nós temos grupos de gestantes, mensal, agora com data fixa, o que antes não tínhamos. No grupo, como é 'Mãe Paulistana, a gente tem que falar do programa, e aproveita pra falar sobre a gestação. A C. sabe fazer 'fuxico' e ela vai ensinar as gestantes no grupo. Então, são coisas assim que mudaram na prática: os grupos aumentaram [e agora têm local fixo], mas não tinham local fixo - 
melhorou muito daquele período pra cá, eu e o médico nos dividíamos, cada hora um tava num lugar e o outro em outro lugar, a gente não se encontrava - agora nós conseguimos ficar fixos numa Unidade, temos visto evolução mesmo de estrutura física, as condições melhoraram muito. Era muita consulta e a gente não conseguia fazer os grupos; a gente tem conseguido fazer planejamento familiar e tem visto funcionar mesmo.

Angela: Quer dizer que as suas práticas educativas aumentaram?

S4: Sim, aumentaram. A gente fazia bem menos.

Angela: E acaba usando um pouco do 'Janelas' em tudo...

S4: É, a gente acaba usando ele em todas as fases da vida; dá pra aproveitar mesmo com o adulto, o idoso que se torna uma criança novamente - tem como resgatar a auto-estima daquele idoso. Na campanha do idoso, nós tivemos como agradar a população naquele dia, ser diferente: nós conseguimos pente, lixa, uma escovinha de cabelo e fizemos um kit pro idoso; uma agente comunitária vestida de Minnie entregou o kit para eles e eles ficaram alucinados. Você tem que ver nas fotos, eles abraçados na Minnie, pareciam crianças. Deve ter sido muito importante pra eles. Então, em todas as fases tem como você fazer trabalho educativo.

Angela: De todas essas práticas, qual é a mais significativa pra você?

S4: Com as crianças mesmo.

Angela: Diretamente com as crianças ou diretamente com as mães?

S4: Diretamente com as mães. Com a família foi a mais significativa.

Angela: Seria a que mais mexe com você? A que você mais gosta de fazer?

S4: É que eu acho importante. Porque trabalhar com a criança é trabalhar com o futuro dela. Então, nós temos o grupo de verminose, de pediculose, e a gente poderia aproveitar esses grupos pra fazer as sensibilizações, porque elas vão e a gente brinca que é o dia da feira, porque elas querem remédio de verme, remédio de piolho. Então, a felicidade delas é você dar remédio de verme e de piolho, e aí está uma oportunidade pra você trabalhar com as coisas.

Angela: Ampliar o foco...

S4: Isso!

Angela: Não só a verminose e o piolho, mas todos os cuidados.

S4: E a gente aproveita, nesse dia, que elas vão porque elas estão interessadas. 
Angela: Depois do 'Janelas', nestes últimos quatro anos, você teve outras experiências de formação? Cursos que você recebeu como educanda ou deu como educadora? Se sim, quais foram eles?

S4: Difícil... Lembra que eu te falei? Depois do 'Janelas', cursos nesse grau, assim, não teve. Teve alguns, mas igual ao 'Janelas' não.

Angela: Você participou de cursos mais pontuais? É isso? Como educanda, participante? Essa música que estamos ouvindo, de pano de fundo, é de um treinamento sobre feridas, bem pontual, né?

S4: Eles estão fazendo esse treinamento para os enfermeiros novos, que entraram nessa fase de expansão. São cursos mais pontuais - tuberculose, vacinas, etc. Antes eu era responsável pela imunização. Hoje, eu sou responsável pela vigilância epidemiológica. Então, eu vivo tuberculose, minha vida é tuberculose (risos), estar sempre em cima [disso], como vigilância mesmo. Agora, como o 'Janelas', não teve. Ah, o que eu fiz de importante e que foi durante o meu trabalho foi a minha especialização. Foi pelo Ministério, junto com Prefeitura.

Angela: E quando foi isso?

S4: Em 2005. Especialização em Saúde da Família. Ofereceram esse curso de um ano para os médicos e enfermeiros. O médico que trabalhava comigo na época também fez. Cada um foi pra um canto, foi muito importante.

Angela: E como educadora, você deu algum curso, deu algum treinamento nesse período?

S4: Não, a gente tem mais educação continuada na própria equipe.

Angela: Voltando à multiplicação do 'Janelas', você fez com o apoio da Supervisão, para toda a Unidade?

S4: Não, nós fizemos com a Supervisora para todo o Distrito. Fizemos numa escola, dividimos a carga horária, os dias, e nós que fizemos, nós quatro, passamos pra todo o mundo!

Angela: Você lembra quantos vocês formaram?

S4: Nossa! Foi um número grande! Acho que chegou a uns 60, porque tinha umas turmas de 20 ou 30, alguma coisa assim. Nós tivemos que fazer em 2 turmas, todas as Unidades participaram (quatro unidades e quatro anexos). Pegamos 0 pessoal da limpeza também, todos mesmo, servimos refeição.

Angela: Ouvindo você, eu fiquei com uma impressão muito forte de que faltou - $e$ falta - experiências de formação e de multiplicação significativas, importantes como foi o 'Janelas'. Me conta uma coisa: e o 'Mãe Paulistana', como foi a implantação? Teve treinamento? Como foi? 
S4: Não. Teve uma capacitação - eu não fui - o pessoal foi pra aprender a preencher a ficha. O que eu ouvi da pessoa que foi é que não teve nada daquilo, não teve uma coisa completa.

Angela: Veja se eu estou entendendo bem: não foi só conteúdo que o 'Janelas' trouxe, no sentido de uma informação de qualidade. Também pelo lado do vínculo, das relações que te transformaram, pra você poder passar isso pras outras pessoas.

S4: É, isso.

Angela: Suas práticas de educação em saúde aumentaram, hoje você tem melhores condições de trabalho.

S4: E poder continuar o trabalho educativo em saúde, que é o que a população precisa.

Angela: E você tinha tido alguma experiência antes do 'Janelas'?

S4: Não, em educação em saúde não. Novos horizontes se abriram com o 'Janelas', por isso ele foi bastante significativo.

Angela: $E$ com as famílias, o trabalho acontece mais nas consultas e nos grupos, mais agora do que antes, pela falta de condições que havia. Eram equipes avançadas, volantes...

S4: Isso, volantes.

Angela: Eu acho que a gente terminou! Só quero te agradecer muito pela tua atenção e disposição.

S4: Espero ter contribuído!

Angela: Contribuiu, com certeza! 
Entrevista ํo 5 realizada em 15.08.2009 (duração: 43 minutos)

Local: na residência

Angela: Vamos conversar sobre as suas práticas de educação em saúde, nesse tempo que transcorreu do Projeto 'Janelas' pra cá. Começando pelo seguinte: o que mudou em você do 'Janelas' pra cá? E o que não mudou, porque você já tinha, já trazia consigo, já fazia parte da sua bagagem?

S5: Eu posso dizer que como enfermeira sempre trabalhei na parte de educação. Desde 92, na Prefeitura, eu estava em Desenvolvimento de Recursos Humanos e fazia muitos treinamentos; montava treinamentos pras equipes de enfermagem, pra outros profissionais também, e a visão era sempre a visão clínica - vamos estudar uma doença, vamos estudar os conceitos e o tratamento, ou a esterilização, dependendo das técnicas da enfermagem. Em 2002, quando eu comecei a ter contato com o 'Janelas', aquilo lá foi assim uma mudança muito grande na minha vida, apesar de eu já ter uma vivência muito grande com cinco filhos, que faz ter um olhar pras crianças, mas, sem dúvida teve uma ampliação muito grande! Primeiro pra entender que a neurociência, que um bebê ou um feto já está recebendo todas essas emoções que a mãe vive, que passam a fazer parte dessa criança pro resto da vida também, isso foi um foco que me chamou muito a atenção. Porque nosso trabalho mesmo como enfermeira tem sido bastante clínico, atende o paciente, atende a gestante, vê suas condições de vida e tudo mais, segue pra uma próxima consulta, pra uma próxima gestante e assim com as crianças também. Então, o 'Janelas' abriu todo aquele horizonte de como é que são essas famílias, como é que são as redes sociais - eu nem sabia direito o que é rede, rede social também - como que essas pessoas vivem, interagem, como que elas sentem, vivenciam essa mudança toda de uma criança dentro da família. O que me chamou muito a atenção quando eu estava aplicando a cartilha do 'Janelas' na própria favela, na comunidade, a gente via que os agentes de saúde falavam de um determinado tema naquele mês com algumas famílias e, de repente, a comunidade toda tava falando daquele tema! Uma família tava chamando a atenção de outra família, assim: 'Olha, os seus vidrinhos de alvejante, de cândida, estão aqui embaixo e a tua criança pode, sem querer, tomar! Você não aprendeu, você não viu o que ela tava explicando?' Então, de certo modo até a população começou a se educar.

Angela: uns aos outros.

S5: uns aos outros. E com isso, a gente dava pra sentir que houve uma melhora significativa na qualidade desse atendimento, e o próprio envolvimento que se viu da família toda com as crianças. Eu observei, nos relatos das agentes de saúde, das mães, de todos, que as mães procuravam conversar mais com seus filhos, e isso graças [ao fato de] a gente começar a conversar [sobre] o que é uma criança, o que quer dizer quando uma criança de três anos fala um não, que esse 'não' não é porque ela está negando a mãe, muito pelo contrario, ela está querendo se afirmar como um ser já independente. Então, com isso começaram a acontecer muito menos discussões entre mãe e filho, começou a se ver que as famílias nem sempre são só mãe e filhinho - muitas vezes tinha o pai, e o que a gente mais queria era envolver a família toda - e os pais começaram a entender melhor seus 
filhos e a conversar mais com eles. Os avós, que são muito presentes na vida das crianças, muitas vezes [porque] os pais saem pra trabalhar, começaram a entender melhor essas crianças. Começaram a entender, e a própria equipe de saúde, o quanto é importante a historinha, conversar, cantar, brincar. Que o brincar não era uma brincadeira de passatempo, mas era o jeito que a criança tem de trazer pra fora o seu mundinho, [de mostrar] como é que ela estava vivendo esse mundo. Então, eu acho que essa visão a gente não perde nunca mais. Aí eu acabei trabalhando muito com gerenciar mesmo as equipes pra manter vivo todo esse trabalho de 'Janelas de Oportunidades' o máximo de tempo possível. E foi até 2007. De 2002 até 2007 nós conseguimos manter.

Angela: Olha que foi um bom tempo, heim?

S5: Foi, e eu tenho tudo isso registrado! (risos). Eu tenho até as planilhas.

Eu tenho todo esse registro porque uma coisa que me chama a atenção, eu sei que estou falando tudo isso junto, desculpa...

Angela: Diga o que the vier cabeça.

S5: É que eu estive em varias situações. A primeira, eu estava na própria comunidade quando eu entrei em contato com esse programa, quando teve alguma divulgação na mídia, fizemos os cadernos e aí foi quando realmente começamos a implantar. Daí nós tivemos também a capacitação dos multiplicadores, que eram outros profissionais de saúde, já não só da equipe de PSF, mas de todas as equipes que faziam parte da Supervisão do Distrito de Saúde. E foi aumentando. Nesse tempo acabei sendo transferida para o Programa Saúde da Família de outra UBS, em 2004, e assumi a continuidade desse programa lá até 2007 . Eu saí de lá em abril de 2008, pra terminar o doutorado. O que eu percebi, até 2006, é que nós tínhamos um coordenador na própria Supervisão de Saúde que solicitava uma resposta, isto é, os dados de produção das equipes. E enquanto ele solicitava, as pessoas respondiam e faziam todo um trabalho. Nós montamos uma planilha anual com itens da cartilha a serem estudados pra que todas as equipes falassem o mesmo assunto em toda aquela área da UBS.

Angela: Deixa eu entender um pouco. Foi você que fez a preparação de todos nessa UBS?

\section{S5: Eles não tiveram muito preparo lá}

Angela: Eles participaram da capacitação, mas a multiplicadora saiu de lá? Eu não me lembro quem era.

S5: Era a enfermeira G. que ficou grávida e acabou não continuando, não teve condições. Aí eu falei [que] isso não podia ficar assim. Conseguimos fazer no Dia da Criança, em outubro de 2006, o dia das 'Janelas de Oportunidades' com as nossas crianças também, e fizemos um pólo de desenvolvimento social [em que] participou o 'Janelas' pra mostrar o trabalho com as crianças. Eu tenho tudo 
registrado com fotos e relatórios também. Nós também elaboramos pra Unidade, uma planilha de como fazer as anotações, como proceder mensalmente...

Angela: Ela era separada ou entrava naquela ficha do PSF?

S5: Ela era separada. Conseguimos colocar na ficha da produção individual dos Agentes Comunitários de Saúde no finalzinho, e as pessoas começaram a aprender: _'Ah, eu atendi 'Janelas de Oportunidades' nessa família que tem tantas crianças, que tem gestante'. Conseguimos fazer todo o registro colocando em que mês, que micro áreas, que famílias, com crianças menores de dois anos, menores de seis anos, e gestantes, em uma planilha que a gente fechava todo mês e mandava pra coordenação. No ano de 2007 não tinha mais coordenação pra receber, mas eu continuei fazendo como se eu fosse da coordenação.

Angela: Ah, então até 2006 tinha uma coordenação.

S5: Sim. Em 2007 já não tinha coordenação, mas eu continuei pedindo e eles continuaram dando os dados pra mim, porque assim eu dava continuidade ao trabalho.

Angela: Quer dizer, mesmo sem o olhar da Supervisão de Saúde você tocou o seu trabalho dentro da Unidade.

S5: Sim. Eu vi que muitas pessoas têm essa consciência da importância de um trabalho desses, mas acabam não conseguindo levar adiante porque fica sendo um trabalho quase que sozinho, continuar com uma bandeira que é tão importante, com tanto investimento material, humano, que é tão atual, sei lá, pra sempre desde que existam crianças com essas características...

Angela: Deixa ver se eu entendi. Eu acho que você está me dizendo que, antes do 'Janelas', você tinha experiência em treinamentos na tua área de enfermagem, mas eram treinamentos bem objetivos, sobre a clínica, né? Aprender um procedimento, etc e etc. Você trouxe com você essa experiência de formadora, de um lado; de outro lado, a sua experiência de mãe de família, mãe de cinco meninas, enfim, com a sua maturidade como um aspecto importante que dá esse 'plus' ao trabalho da gente. Então, isso é o que você considera que você já tinha. $O$ que o 'Janelas' te trouxe, que você pontuou até agora pra mim, seria o seguinte: elementos conceituais importantes da neurociência, aqueles conteúdos sobre o desenvolvimento do cérebro, com ênfase nas relações, certo? Você está falando de todo um relacionamento de conversas, da ênfase em ouvir a criança, entender que a criança é mais do que...

[S5 foi confirmando com a cabeça, verbalizando que sim.]

S5: Não é um adulto em miniatura, ou um simples receptor, que essa criança tem muita coisa pra trocar, e a própria 'janela' que, como a gente viu, essa hora em que [a criança] está absorvendo tudo, não tem noção de conceitos, tudo está sendo absorvido como uma realidade, e aquilo vai ser a bagagenzinha dela que ela vai estar levando depois pra vida. 
Angela: Teria mais algum aspecto do 'Janelas' que chamou a tua atenção, que seria esse elemento novo que contribui pra tua formação, nessa perspectiva que você mesma diz, que a gente adquire e não perde jamais?

S5: Eu posso até dizer que, nas consultas individuais de enfermagem que eu faço no Programa de Saúde da Família, tanto de gestante, quanto de criança, de mãe ou de pais, eu faço questão absoluta de trazer o companheiro da gestante, quer dizer, a pessoa que é o pai. Faço questão de conversar sobre se essa criança é homem ou mulher, menino ou menina, qual vai ser o seu nome, e já começar a chamar essa criança pelo nome. Eu faço questão também de que o pai entenda a necessidade dessa gestante, de que ela precisa de calor e carinho pra poder gerar esse ser dentro dela, o quanto é importante ele estar junto dela e até preparar [antecipar] que quando o bebê nascer, a mãe vai ter um contato muito maior e que só aquele silêncio dele do lado dela já é muito importante para o aleitamento, para a paz da família, estando todos juntos. Agora, muitas vezes entra no consultório uma mãe com três crianças e eu acho bom. Antigamente era [pra ficar] lá fora; agora não, entram todos juntos - eu já tenho os meus lápis de cera, enquanto isso eles brincam, conversam - e eu vou vendo a integração dessa família. Então, não é mais aquele olhar focado nos problemas, nas doenças, mas amplia para a saúde, para como é que eles estão interagindo entre eles.

Angela: E você se sente bem recebida pelas famílias, de uma forma geral?

S5: Com certeza, o vínculo fica impressionante! Até hoje, eu mesma sinto muitas saudades das pessoas, mas as pessoas também me procuram até hoje, porque 0 vínculo fica muito verdadeiro, muito mais completo, mais integral. É assim que eu sinto. E é uma troca, eu não vejo mais como uma imposição, eu como técnica falando como tem que ser feito. Muito pelo contrário, aprende-se a ouvir muito mais, e essa interação toda das crianças com a família.

Angela: A gente está percorrendo esse período todo, de 2004 até aqui, e eu queria que você me falasse das suas práticas para além do 'Janelas', entendeu? Talvez, outros cursos que você tenha dado, ou recebido, outras experiências de educação em saúde, promoção da saúde, com foco na criança, ou não... Enfim, para ampliar um pouquinho o nosso olhar para além do 'Janelas'.

S5: Eu acho que essa experiência vai se ampliando, inclusive quando se faz uma educação continuada com os profissionais - com os auxiliares, com os enfermeiros. Porque essa visão de conversar, essa visão de abrir caminho acaba aumentando até para as outras idades; dá uma proximidade maior com um auxiliar [de enfermagem] que tem algum problema com seu filho, ou que está gestante, ou que pode encontrar algum paciente que vai lá fazer inalação, e o seu olhar fica mais ampliado e fica mais humanizado, mais sério, mais integral.

Angela: E você incorpora mesmo, né? É um aprendizado verdadeiro.

S5: Incorpora, é verdade. E isso acaba refletindo em tudo o que eu for fazer. Se eu for lembrar um pouquinho dos cursos que eu fiz... Eu acabei entrando no 
doutorado e terminei no final de 2007; ele mudou muito a minha vida porque, na hora de escolher o tema, eu escolhi um tema que pudesse ampliar. Neste caso, eu fui estudar a enfermagem pelo lado da antroposofia, no sentido de que não se vê apenas o corpo físico, mas todo o corpo energético, o emocional, a identidade do ser humano, desde quando está sendo gerado, até o seu último dia de vida aqui.

Angela: Você é antroposófica desde quando?

S5: Olha, só desde 98, é uma coisa nova! (risos).

Angela: Veja bem. Isto é uma coisa que você já traz para o 'Janelas', não é? Você já tem uma formação cujo olhar é ampliado.

S5: Tem um pouco sim. Porque em 2000 eu terminei a formação antroposófica de poder ver o ser humano de um modo um pouco mais ampliado. E não era fechado pras crianças; do jeito que a gente trabalha na saúde coletiva ou na saúde pública, no programa saúde da família, isso fez um ganho sim. Pelo protocolo, a gente tem esquematizado o que é importante fazer pra que essa criança tenha saúde, mas não vai mais a fundo no por que está acontecendo, quais são os problemas reais. Então, a gente tem que trabalhar na parte dos determinantes.

Angela: Sim, mas eu estou entendendo que a sua formação já é um facilitador, não é?

\section{S5: Com certeza.}

Angela: Por conta da sua formação em Antroposofia. E aí faz sentido a gente parar e conversar um pouquinho sobre isso. O que seria essa ampliação na Antroposofia? Ampliar o olhar pela Antroposofia abre pra muita coisa, não é?

S5: Sim. Eu acho que tem muitos valores, tanto na religião como em outros setores da vida da gente, que a Antroposofia conseguiu trazer, mais didaticamente, alguns aspectos que não tem volta. Se você começa a enxergar o ser humano integral, um ser humano que não é só físico, mas tem seu emocional, é uma identidade espiritual, você começa a ver que o que acontece no físico é uma manifestação última do que vem como problema desde o seu lado espiritual, ou de relacionamentos emocionais que ele está passando. Então, o olhar antroposófico mostra que o ser humano é também participante da sua realidade, daí a importância de trabalhar com um pai e uma mãe que estão gerando um filho, porque eles estão ajudando na formação espiritual, mental, emocional e física desse ser. Então, [fica claro] o quanto é importante a gente começar a atuar desde a gestação. E essa visão, a gente não tem, a gente não tem na faculdade, não tem em outros lugares, e é quando a gente está começando a olhar o ser.

Angela: Aí você vê como vai...

S5: Indo e vindo... 
Angela: Vai interligando tudo. Você estava falando de determinantes sociais, quando eu te perguntei sobre o que você trazia da Antroposofia. Vamos retomar o determinante social. E a dimensão social, como é que você coloca em tudo isso?

S5: Fatores sócio-econômicos, culturais, todos esses fatores acabam influenciando. Então, um ser, uma criança, não importa se vem de uma comunidade muito carente ou com todos os benefícios, ela é um ser característico que precisa de um cuidado pelo fato de ser um feto ou uma criança de até três anos ou seis anos. Agora, sabemos que esses determinantes sociais podem agravar ou dificultar o desenvolvimento dessa criança. Ao mesmo tempo, sabemos que tem crianças que conseguem muito bem sobreviver em situações muito difíceis - a resiliência que a gente aprendeu no 'Janelas' - crianças e gestantes que conseguem superar tão bem uma situação tão difícil. Então, todos esses aspectos são muito estudados. E nas visitas [domiciliares] do Programa Saúde da Família, por exemplo, isso é muito importante pra saber como é esse ninho que eles estão formando para a criança que vai chegar; se eles precisam de ajuda pra entender isso, pra receber bem a criança e ela desenvolver bem todas as suas capacidades.

Angela: Em que pese as situações desfavoráveis, de carências materiais, etc.

S5: Sim, exatamente. Porque a gente vê famílias que tem muita pobreza, muita dificuldade, mas tem esse calor humano, de formar, de receber um ser e dar chance pra essa criança desenvolver essa resiliência, com mais equilíbrio, e depois ser um adolescente que também consiga passar melhor por essas fases de drogas e de violência e tudo mais.

Angela: Pensando numa situação socialmente bem desfavorável, numa família com carências desse tipo, como seria lidar com esse fator social desfavorável? Como seria isso pra você? Como é que você pega esse elemento como elemento diagnóstico e de orientação para a sua intervenção?

S5: Um exemplo da nossa realidade: tem lá uma família, acho que ela tem sete filhos, todos pequenos, o marido está preso porque vendia drogas e a mulher com as crianças vira e mexe aparecem lá no posto de saúde. Então, esse 'vira e mexe no posto de saúde' a gente começa a entender diferente. Essas crianças e essa mãe estão buscando alguma coisa que encontraram no posto, alguma coisa que encontraram com esses profissionais de saúde. Então, numa situação dessas, é ouvir, entender um pouquinho o que essa mãe está trazendo; onde está, nas entrelinhas, o que ela realmente está precisando, e que não é aquele paracetamol para aquela dor de cabeça. Tem algo muito maior por trás, que a gente pode estar levantando, e aí entram os determinantes, isto é, a rede, quem vai poder ajudar, porque são tantos problemas que aí você começa a contatar a assistente social, o conselho tutelar, outros aspectos que podem estar ajudando a fortificar essa família, pra que essa criança possa viver com um pouco mais de equilíbrio e ter um futuro melhor.

Angela: Quer dizer, é aquela percepção de que nem você nem a família estão sós, né? A idéia de uma rede de apoio para a família. 
S5: Exato. Isso mesmo. Exatamente. Tivemos um caso de uma mãezinha de 18 anos que não queria ficar grávida, muito jovem, ela batia na própria barriga, não queria o bebê. Infelizmente esse bebê nasceu e depois de três meses o bebê morreu. Aí, veio a Vigilância toda em cima [perguntar] por que esse bebê morreu? Quer dizer, e essa mãe foi trabalhada, quer dizer, você vê que, às vezes, tem casos que você não consegue atuar. Hoje, essa mãe morre de remorsos, mas já é tarde. Quem sabe numa próxima gestação ela vai pensar diferente.

Angela: Algum ganho, algum aproveitamento há de ter... Pensando de novo no 'Janelas', na multiplicação que você fez, na formação das pessoas, elas incorporaram essas coisas de uma forma verdadeira? Eu penso em processo verdadeiro quando a gente aprende e fica, né? (risos) Fica integrado na nossa prática do cotidiano. Como é a tua percepção disso? Porque você falou de famílias em que você realmente viu surgir um processo de apoiar mais a criança, aceitar melhor a criança, estimular a criança. E os colegas, heim?

S5: Boa pergunta! Eu vejo assim: têm uns que se envolveram, outros que não. $E$ quando a gente quer que alguma coisa dê certo, a gente puxa por aqueles que se envolveram! $\mathrm{E}$ eu sou muito assim (risos). Eu tenho muita paixão por esse programa todo, então, eu só vejo aquelas pessoas que se envolveram. Nessa Unidade nova em que eu estou trabalhando há quatro meses, eu tenho uma cartilha comigo e, às vezes, eu pergunto: _Você já viu isso alguma vez?'. As pessoas mais antigas já viram; as outras não, porque não teve mais divulgação, apesar da gente saber que está na internet. Só que precisa estar trazendo de novo.

Angela: Você está tentando resgatar lá?

S5: Estou tentando, porque eu acho que a gente vê uma verdade, tem que estar buscando passar...

Angela: Teve 'Janelas’ lá né?

S5: Teve sim e acho que foi um dos primeiros.

Angela: Qual é mesmo a Unidade?

S5: A USF VA. Acho que foi em 2001, muito cedo. Viram a necessidade.

Angela: Eu estive lá, eles participaram da linha de base...

S5: E o que acontece? De certo modo, a gente tem uma rotatividade de funcionários, tanto agentes de saúde, médicos, enfermeiros, auxiliares. Então, se a rotatividade fosse entre as próprias Unidades já capacitadas seria mais fácil manter. Se não, teria que estar fazendo uma capacitação, nem que fosse a cada dois anos. Dá pra bolar uma educação continuada permanente, escolhendo e falando de um aspecto da cartilha, que seja mensalmente. Porque, de algum jeito, 
nas pessoas que realmente sentiram e vivenciaram isso, está dentro delas. Basta esquentar um pouquinho que o negócio começa de novo.

Angela: Sim, claro, você não vai puxar por quem não se envolveu com a proposta, vai cuidar de quem se envolveu. E por onde é que eles se envolvem? Como é que você percebe isso?

S5: Olha, uma coisa que eu acho muito interessante é o depoimento dos próprios agentes de saúde, eles que vão todos os dias nas casas das pessoas. Eles falavam assim: _'Era muito legal ter o programa das janelas, porque a gente tinha um tema pra falar com aquelas famílias e todo mundo falava aquele mesmo tema. Então, a gente não ia só perguntar como é que está a vacina, se está em ordem, e tudo o mais, mas podia falar dos agravos, dos riscos, ou [de] como a criança aprende'. Então, eram temas assim pequeninhos, mas que despertavam um pouco mais esse olhar ampliado pras crianças.

Angela: E era feito nas casas?

S5: E era feito nas casas. A princípio, não só nas casas, como nas consultas, nos grupos. Agora existe um grupo chamado GEARA, que as pessoas todas vão lá, onde também dá pra conversar. Porque quando a gente quer... Eu sempre falo: onde há vontade há caminho (risos). E daí as coisas podem acontecer mesmo. Eu tive a oportunidade de levar essa experiência pra Botucatu. Eles tinham chamado pra falar um pouco como é que...

Angela: Espera aí. Conta isso!

S5: (risos) Foi muito legal, foi em 2004.

Angela: Você foi levar a sua experiência de trabalho, mesmo sem o 'Janelas'?

S5: Eles pediram pra eu levar meu trabalho de PSF, pra dar uma palestra lá em Botucatu. Aí, eu aproveitei pra falar do 'Janelas' também e eles gostaram muito. Recebi e-mails de médicos de outras unidades pedindo pra gente levar essa programação pra lá. Só que, como a gente acaba se envolvendo muito no dia a dia, não foi dado continuidade. Mas eu sempre penso: existem sementezinhas que a gente vai plantar e nem sabe onde e nem quem vai colher; importante é plantar porque a gente quer o bem e o melhor pras crianças e pra nós mesmos.

Angela: É um pessoal da Antroposofia lá em Botucatu?

S5: Não, foi da própria faculdade de Botucatu, da UNIFESP. Que eu lembre, foi para os residentes de PSF.

Angela: Qual foi a sua prática de educação mais significativa?

S5: Por incrível que pareça, acho que foi justamente receber esse material e poder multiplicar. Ver que dá pra você passar pras outras equipes e depois ampliar para os outros profissionais; que numa rede você consegue trazer tudo isso; e que é tão 
simples e ao mesmo tempo é possível abranger tanta mudança. Eu acho que esse foi o mais bonito, porque os outros são muito pontuais - você vai fazendo o treinamento, tá, tchau e benção - você não tem mais muita ligação com aquilo lá, mas nesse não, você está envolvida e envolve mais pessoas, formando uma rede.

Angela: E é uma prática de formação dos colegas, das equipes.

S5: Sim.

Angela: E a gente também pode pensar que você faz a formação das famílias?

S5: Sim

Angela: A formação das famílias você também colocaria nesse mesmo patamar, ou não?

S5: Com as famílias... Deixa eu ver se entendi direito. Quando eu faço algum grupo, de mães ou de crianças ou de gestantes, a gente aborda o tema, [e a discussão] fica muito entre elas, a gente fica meio como mediadora e fica pra entre elas estarem conversando, como elas fazem, e você vai colocando o tema da cartilha. Já fizemos muitos grupos [assim]. Lembrei agora: cada mãe tinha a cartilha e a gente lia um determinado assunto, por exemplo, o 'Nó do Afeto', que fala sobre o pouco tempo pra se encontrar [estar com a criança], como é que faz em casa, as dicas que dão e como é a vivência de cada um. Então, é um pouco diferente nesse tipo [de grupo] em que as pessoas estão trazendo as suas vivências e a gente está ajudando a transformar. Quando a gente faz pra formador, pra capacitador, vai muito mais conteúdo, teórico e prático; são conteúdos que têm que ser passados para a própria pessoa, estando ou não presente o seu formador, ter esses conteúdos dentro dela e estar transmitindo.

Angela: Então, tem uma diferença aí, quer dizer que tem um elemento informativo para os profissionais de saúde, além das vivências, e com as famílias é uma coisa muito de construir a partir...

S5: Da realidade dela. Sim, é isso mesmo.

Angela: Sim, e o que estava perguntando é se dá pra colocar em patamares diferentes de importância...

S5: Acho que tudo é importante, muito importante! (risos)

Angela: Sim, claro... [concordando]. Mas é que às vezes você poderia pensar assim: dá pra avançar na formação dos profissionais de saúde, mas temos dificuldades com as famílias, alguém poderia me responder isso... Não é assim que você está enxergando, né?

S5: Não, não. É lógico que você vai encontrar problemas muito sérios nessas famílias, e vai precisar da rede de outros profissionais e da rede da própria família para ajudar a solucionar; então, você vai ter esse tipo de ampliação. E com os 
profissionais, também vai ter outros tipos de ampliação pra eles poderem estar atuando com as famílias.

Angela: É uma experiência significativa de formação, dos teus colegas, das equipes, mas também de formação das famílias.

S5: Das famílias também, porque senão não valeria a pena, você ficaria muito no teórico, como antigamente.

Angela: E pra terminar, eu perguntaria se você teve, depois do 'Janelas', alguma outra experiência da qual você participou como educadora ou como educanda e que foi importante, significativa pra você?

S5: Depois do 'Janelas'... É que o 'Janelas' fez parte da minha vida de 2002 a 2007, concretamente, na atuação com as equipes de PSF. Deixa eu ver... Só lembrar um pouquinho da minha carreira (risos) que eu nem me lembro tanto assim... Deixa eu ver... Olha, eu participei de uma mesa redonda na USP sobre Educação e Saúde e, de certo modo, foi muito colocada essa metodologia de estar lidando com a ampliação.

Angela: Em que ano?

S5: Foi no ano passado.

Angela: E o seu mestrado?

S5: Foi em 2002.

Angela: Qual foi o seu tema?

S5: O meu mestrado foi sobre as terapias complementares e alternativas que os enfermeiros usam, ou não usam, em unidades básicas de saúde. Então, eu já tinha um pouquinho desse olhar ampliado por conta de vivências minhas mesmo.

Angela: Não foi concomitante com aquelas primeiras oficinas com o pessoal dos Distritos de Saúde que, pelo que eu entendi, você também participava? Era pra ajudar a preparar o material do projeto, a cartilha.

S5: Eu não estava ainda. Eu entrei em novembro de 2002, tanto que meu primeiro contato com o 'Janelas' foi nessa reunião de 9 de maio de 2003 [consultando anotações pessoais].

Angela: Qual foi?

S5: Foi o lançamento [lançamento oficial do projeto].

Angela: Nossa, formei uma impressão de que você tinha participado das oficinas anteriores a essa, que foi a terceira, e os materiais estavam prontos. 
S5: É, foi em 2002, quando eu entrei no PSF. E pelo dado que eu tenho aqui, foi em maio de 2003 que eu tive o primeiro contato.

Angela: Foi quando se estava propondo as capacitações... E você já estava fazendo o seu mestrado e já tinha essa linha de ampliação pela Antroposofia...

S5: No mestrado ainda não tinha a Antroposofia, nem tinha muita idéia.

Angela: Mas, não eram terapias complementares? Não era Antroposofia então!

S5: Não, não. Era um levantamento pra saber o que se estava usando de ampliação.

Angela: Homeopatia, acupuntura?

S5: Exatamente. As enfermeiras falavam que usavam florais, reiki, homeopatia, todas as outras coisas. A Antroposofia nem era um nome que saía.

Angela: Ela foi incorporada como terapia complementar muito mais recentemente, não é?

S5: Exato.

Angela: Foi uma das lutas da Iracema, que a levou a Brasília!

S5: Foi sim! Ah, esqueci de te falar que em alguns congressos eu tenho levado esses trabalhos todos, mais da enfermagem antroposófica, que traz essa visão mais ampliada.

Angela: Ah, então, esse seu interesse pela ampliação, olhando através das terapias alternativas, deve ter te conectado com a Antroposofia. É isso?

S5: Creio que sim, porque de algum jeito este é um caminho muito didático para entender essa ampliação, essa integralidade, que não se consegue ver nas outras.

Angela: E aí você começou a sua formação?

S5: Eu só fiz formação biográfica - não fiz a da medicina antroposófica - pra entender um pouco a evolução do ser humano, suas características em cada setênio, como trabalhar as terapias biográficas. Eu fiz [dei] um curso desses pros agentes de saúde da minha equipe, que também divulguei em Brasília, em 2004. E tudo isso realmente acabou ajudando, porque os agentes de saúde falavam que entender melhor cada fase da criança deixava-os mais à vontade e mais seguros pra cuidarem das famílias das suas [micro] áreas. Antes eles diziam: _'Mas eu nunca fui mãe, eu não sei como cuidar'. E assim eles tinham mais instrumentos pra poderem chegar um pouquinho mais perto...

Angela: E esse curso biográfico não é uma formação curta não, pelo contrário... 
S5: Foram dois anos e mais um pouco...

Angela: Que te coloca em contato, de fato, com todo o referencial da Antroposofia?

S5: Sim, sim. Foi de 1998 até 2000, quando eu estava trabalhando em uma clínica oncológica que tinha essa visão antroposófica, foi meu primeiro contato, que me fascinou por trabalhar o ser humano numa verdade bem profunda.

Angela: Você acha correto eu concluir que, de 2004 pra cá, no PSF do município de São Paulo não ocorreu nenhuma outra formação que chegasse perto do 'Janelas', nesse sentido da ampliação, de um olhar mais integral?

S5: Olha, com toda certeza, pode fechar.

Angela: Que pena né?

S5: Pode colocar assim. Mas, eu sempre tenho aquela esperança de que é como uma onda: vai um pouquinho, volta, daqui a pouco vem com mais força, quando é uma verdade. O que a gente sente muito é que sempre foi assim no serviço público: passa uma temporada - quatro anos, eleições - muda-se as equipes e as prioridades, mesmo aquelas que estão dando muito certo eles acabam trocando por outras. Com isso, tem uma perda muito grande pra população, pros profissionais de saúde que se sentem bastante desestimulados, porque eles têm aquele conhecimento, querem fazer porque sabem que dá resultado, e dizem que agora não é mais isso, que é outra coisa...

Angela: Pois é, e mesmo fazendo muitos cursos, eles são pontuais, não trazem esse elemento...

S5: De integração.

Angela: De integração do emocional, do social, enfim...

S5: Exato. Hoje eles tentam falar um pouco mais sobre a humanização e o acolhimento, mas quando se fala de humanização e acolhimento ainda se fala de elementos pontuais. Pra você entrar na humanização - que é um termo que tem que ser discutido - e no acolhimento, você tem que ter uma formação interna, porque isso daí você não vai aprender de fora pra dentro (grifo meu); quem não vivenciou isso na sua própria família, dificilmente vai conseguir estar vivenciando isso lá fora.

Angela: É que tem a nova política, o HumanizaSUS, não é?

S5: Sim

Angela: Como é que ela está chegando lá [na base] pra vocês? Seriam ações pontuais também? Como é que isso está chegando pras pessoas? 
S5: Dá pra ver claramente quando alguém entra para um posto de saúde: na humanização, ele tem que ser bem atendido e rápido, ter efetividade, que saia satisfeito, com a resposta que estava procurando. Então, mas isso aqui é uma coisa do BE A BA que tem que estar acontecendo em todo lugar de trabalho. Então, isso não está voltando ao olhar ampliado do 'Janelas'. Há um grande risco de cair, de novo, no atendimento clínico e só fazer a produção numérica e não de qualidade. $\mathrm{O}$ que um trabalho tão belíssimo e profundo como o 'Janelas' pede é qualidade. E qualidade exige tempo. Você sabe que pra ajudar a mudar uma realidade importantíssima você gasta três/quatro horas em uma visita domiciliar com determinada família e isso não vai contar na sua produção como várias produções; vai contar como uma única produção e você vai ter que explicar porque você não alcançou a sua meta. Então, essa conversa toda de produtividade, de qualidade versus quantidade, é uma conversa que tem que ser revista. A gente vê hoje exigirem muita qualidade no trabalho, que eu acho fundamental, mas com uma produtividade cada vez maior, e os profissionais, com isso, estão muito desgastados. Este é o meu olhar. Eu já vivenciei isso muitas vezes: [os profissionais] acabam não conseguindo se envolver por um tempo mais prolongado com uma determinada comunidade, e com isso...

Angela: Estão exauridos.

S5: Estão exauridos. Exato.

Angela: Valeu. A gente concluiu. Obrigada! 
Entrevista ํo 6 realizada em 09.10.2009 (duração: 74 minutos)

Local: na clínica particular

Angela: No campo das suas práticas de educação, o que mudou em você, do 'Janelas' pra cá? E o que não mudou, porque você já tinha, já trazia com você pra essa experiência?

S6: Bom, [em relação a] a primeira parte da pergunta, é especialmente o olhar sobre a criança, porque, muitas vezes, eu observava que as pessoas passavam pela criança sem sequer notá-la, talvez pelo tamanho menor que as crianças têm, menor estatura que as crianças possuem né? E, principalmente, depois do 'Janelas', nunca mais uma criança me escapou do campo de visão. Então, você amplia a sua visão de mundo para incluir a infância, em minha opinião. Essencialmente, eu diria que é o olhar para a criança, o olhar para a infância, principalmente para o período mais importante da formação da criança, desde o pré-natal ou até mesmo o período da concepção, da pré-concepção, passando pelo pré-natal e os três primeiros anos que duram para sempre.

Angela: Eu posso tomar o que você está dizendo em sentido literal? Assim: _eu não me interessava por criança, eu não enxergava, eu não via criança'. Aí, você passou a se interessar por ela, passou a enxergá-la? Porque antes ela não entrava no seu universo...

S6: Então, o meu universo de clínico geral, que é a minha formação mais básica, sempre viu a pediatria como outra especialidade, portanto, as crianças não eram destinadas a nós e nem nós a elas. Agora, no meu caso em particular, eu sempre tive oportunidade de conviver com crianças em estado de adoecimento, fosse na época do internato, fosse pela infectologia que eu escolhi depois, que avalia a atuação do agente hospedeiro, independente da idade. Dessa época em diante, eu passei a atender crianças, e depois também, com a formação de médico generalista. Eu acredito que o que houve foi uma ampliação do olhar sobre a criança, ampliação e também um aprofundamento. Amplia e aprofunda.

Angela: Conte-me mais sobre isso, sobre o que você passou a ver - ficou claro pra mim que a criança não estava fora do seu universo de médico, mas que você passou a enxergá-la de uma outra forma. Conta mais, especialmente sobre essa criança dentro da barriga da mãe, durante o pré-natal e durante os primeiros anos de vida.

S6: A primeira coisa que me veio é que a fecundação, a embriogênese sempre me despertou muita curiosidade, e o processo de tornar-se pessoa a partir de um substrato biológico sempre foi um tema bastante interessante, muito interessante. $\mathrm{E}$ eu acredito que, na hora em que a gente amplia e aprofunda, e nesse sentido o 'Janelas' traz essa oportunidade, o olhar da formação desse ser para além desses parâmetros biomédicos, incluindo aspectos espirituais e até mesmo sociais, ou principalmente sociais, porque quando a gente trabalha famílias e redes, isso é um aspecto que vem à tona, então a gente parece que começa a compreender como se dá o processo de formação em seu momento mais crucial, em seu momento 
mais importante. Uma vez que, do outro lado, atendendo adultos, a gente verifica seqüelas de todo esse processo de formação, seja na embriogênese, seja no período anterior à embriogênese, seja no período de desenvolvimento fetal, seja no período do periparto, seja no período da lactância, seja depois no período de 0 a 3 anos de idade e até os 6 ou 7 anos de idade - ou como no caso do projeto o recorte é até seis anos. Então, a gente vai vendo as seqüelas e, na verdade, a gente vai vendo um elo de ligação, né? Eu acho que, ao ampliar e aprofundar o olhar sobre a infância, fica um pouco mais clara a trajetória desses adultos, onde a criança se encontra menos visível, já que existem muitas modificações, não é?

Angela: É como se você estivesse falando de uma conversa do biológico - isso que você refere como um olhar sobre a criança baseado em aspectos biomédicos com os aspectos sociais e espirituais até. Esses aspectos espirituais têm muito a ver com a sua formação, que eu conheço um pouco... Nas oficinas de formação do projeto, você identificava esses aspectos do olhar que se constitui pelo social e pelo espiritual, nesse caminho de desenvolvimento da criança para o adulto?

S6: A questão espiritual é inclusive biológica, e uma das formas de espiritualidade, talvez numa linguagem mais próxima da vivência do bebê, é a alegria do evento, que é um momento de intensa atividade, que é bem visível na criança. Quando a criança está excitada, quando ela está feliz, quando ela está brincando, ela saltita, ela emite sons, dá pequenos gritos, riso fácil, e o corpo funciona de uma maneira harmônica, porque o impulso que é gerado no centro, no coração, rapidamente atinge as extremidades. Então, talvez não precisemos falar de uma espiritualidade transcendental; podemos falar de uma espiritualidade presente no próprio corpo. $\mathrm{E}$ também podemos falar de uma mente inteligente, de uma mente que interage, como uma forma de espiritualidade. Então, talvez esses sejam os aspectos espirituais a que eu possa me referir nesse momento, até pra ficar um pouco mais coerente com a abordagem que a gente está fazendo. Agora, os aspectos sociais são fato, porque, por exemplo, como a capacitação se dava com uma carga horária que permitia a dispersão, e imediatamente você podia verificar a aplicação dos conteúdos teóricos, bastava que você fosse a uma visita domiciliar, que se dava nos núcleos populacionais, geralmente na periferia; bastava que você adentrasse as vielas desses núcleos populacionais para, imediatamente, conseguir fazer associações entre os conteúdos da própria multiplicação, que estavam fresquinhos, e a realidade que se encontrava. Por exemplo, poder olhar uma situação familiar ou, melhor dizendo, poder olhar uma criança como ponto de partida pra entender, pra compreender os complexos laços sociais que estão determinando o seu presente e o seu futuro, torna-se muito possível. Olhar uma criança sem conseguir estabelecer conexões entre os seus cuidadores mais imediatos e a sua rede social é deixá-la tão sozinha quanto não enxergá-la, quanto ela não ser vista.

Angela: Você está enfatizando a rede social nesse aspecto relacional mesmo.

S6: Relacional, como suporte, mas também como uma rede que vivifica, uma rede que traz significados variados para a própria vida! Lembro de um dos conteúdos das oficinas que é um dos capítulos iniciais da cartilha, valorizando a vida, que orientava o cuidador a valorizar qualquer aspecto vital que encontrasse pela frente, 
fosse uma planta, fosse um pequeno animal. De certo modo, ao entrar na casa das pessoas, já havia pontos de contato pré-estabelecidos: nós vamos buscar a vida, mesmo que ela esteja adormecida - pode ser uma planta, meio sem água, um pouco desidratada, como pode ser uma criança desnutrida, fazendo um paralelo [com a planta]; ou um animal muito querido. Então, essa era uma forma muito interessante de entrar nas casas. Então, eu entendo sim os laços sociais como vitais, e mais vitais ainda para as crianças - que ainda não trabalham e dão trabalho - e precisam dos adultos para crescer.

Angela: Eu não queria perder, queria pontuar um aspecto que você abordou que me chamou muito a atenção e que tem a ver com esses momentos de concentração e dispersão da oficina. Você apontou como aspecto de valor nessa metodologia que ela possibilita esse contato para 'exercitar' o que você aprendeu, o que te pegou mais forte. Essa é uma questão importante...

S6: Sem dúvida. Eu fico até pensando que uma capacitação de 40 horas é excessiva. Mas, a partir dessa reflexão sobre a importância da dispersão, é o contrário, ela se torna mais eficiente.

Angela: Porque veja: é muito diferente você fazer uma capacitação de 40 horas seguidas, ficando cinco dias concentrado - é muita coisa, é muito cansativo - do que você fazer um dia inteiro por semana, com o restante de dispersão, pra depois voltar e continuar.

S6: Então, talvez, a natureza da experiência de formação com essa metodologia seja diferenciada mesmo, porque na hora em que você pode de imediato associar prática e teoria, eu acredito que isso se torna verdade, uma verdade provavelmente útil, porque ela vai interferir na qualidade da atenção que você presta ao seu paciente, ao usuário, a criança ou a família. E mais importante ainda, talvez, seja o nosso papel de nos prepararmos para multiplicar. Então, talvez, não havia duas tarefas implícitas: uma de checar na prática - eu não diria checar porque seria algo tarefeiro - mas constatar a teoria na prática, e a própria vivência, pois essa formação também teve muitos aspectos vivenciais. Então, não se tratava só de verificar a teoria, tratava-se também de compartilhar a experiência.

Angela: Lá, na concentração...

S6: Lá mesmo na concentração e depois na dispersão. $E$, com isto... [pausa] Retomando, talvez, a natureza da experiência seja diferente, porque não se trataria apenas de verificar conteúdos, mas de incorporá-los às práticas, e, ao mesmo tempo, preparar-se para ser um transmissor deste conhecimento. Eu diria que havia questões subliminares, implícitas, na proposta da oficina que era formar-se e, ao mesmo tempo, formar-se para formar. Formar-se a si mesmo e, imediatamente, formar-se para formar, já que no final da capacitação a gente teria que produzir um modelo de multiplicação. Então, eu diria que um processo de dispersão com uma proposta implícita como essa, no mínimo, deve ser tido como fundamental.

Angela: Vamos retomar a segunda parte da minha pergunta? 
S6: (risos) Pensei que você não ia se lembrar... O que eu já trazia e que não se modificou?

Angela: O que você percebe que você já tinha e que, talvez, ressoasse com essa proposta, com essa experiência [do projeto 'Janelas'].

S6: Ah, eu já tinha abertura para explorar novos campos do saber, do conhecer. Porque, se alguém te propõe ser multiplicador de um projeto que envolve crianças, necessariamente você não aceita de cara se não é uma coisa que está em paralelo com a sua prática diária né?

Angela: Ou com os seus interesses...

S6: Com o que você já cuidava...

Angela: Ou com a sua formação anterior...

S6: Eu acho que eu já trazia isso, eu trazia uma certa abertura, um desejo de explorar, até mesmo porque - olha, isso é um lado [meu] extremamente infantil (risos) - essa abertura pra explorar e pra buscar novas experiências. Mas esta é uma experiência marcante para mim porque ela integraliza a visão de ser humano que, talvez, na minha própria formação tivesse ficado um pouco a desejar, já que não me lembro dos conteúdos da faculdade, nem mesmo da Residência Médica, nenhum tipo de atenção que se voltasse para a ampliação do olhar biomédico, principalmente para a infância. Até mesmo porque o que se discute em relação a família e rede social não serve apenas para a infância, embora a criança fosse o nosso objeto de atenção. Na verdade, isso você leva para a vida inteira. Então, esse olhar sobre família, esse olhar sobre rede, você vai levar pra sempre. Aliás, eu acho que a multiplicação enfatizava isso. Até mesmo porque ela solicitava que, nos trabalhos de rede, nós buscássemos exemplos cotidianos nossos; nós éramos obrigados - obrigados em termos, levados ou solicitados - a buscar exemplos em nossa própria comunidade, aquela de onde nós nos originávamos: a quem pediríamos uma xícara de açúcar ou um pouco de café. Isso já colocava a experiência muito além do cuidado com a criança. Então, eu acredito que se torna marcante por isso. É uma experiência integrativa, porque você está olhando para a criança, olhando para si mesmo e olhando para o seu entorno - o seu próprio - no seu próprio processo de formação, para depois, ao se localizar, poder também olhar para o outro e para o entorno desse outro.

Angela: Você marcou um aspecto interessante, que não dá pra olhar a criança solta, sozinha. Você tem que, necessariamente, olhar o cuidador e, portanto, a si próprio nesse processo.

S6: Não teria como fazer uma pausa? [pausa de 20 minutos]

Angela: Fale um pouquinho mais dessa sua característica 'infantil' que tem a ver com a curiosidade, o desejo de explorar, de conhecer, de aprender... 
S6: Tudo vai depender primeiro da abertura. Fiquei pensando como que seria você formar pessoas, formar multiplicadores que estão fechados - fechados para a experimentação ou para aprender. Está aí uma boa questão: _Como é que se pode contribuir numa multiplicação - e aqui eu estou tentando recordar a multiplicação que foi feita no 'Janelas' - para promover a abertura. E aí me ocorreu de imediato que uma das coisas fundamentais é que haja empatia. Então, eu não saberei te dizer agora em que momento especificamente isso foi trabalhado, mas me lembro da organização [da oficina de capacitação]. Eu acredito que a organização da multiplicação talvez pudesse promover um pouco dessa empatia, que vai desde o cumprimento dos horários, o cumprimento do combinado, a tratar o outro como uma parte muito importante nesse relacionamento - neste caso, os formadores e os multiplicadores - passando pelo almoço, pela flexibilidade que era possível ter no planejamento das ações dentro da capacitação e, ao mesmo tempo, um grande contorno que era dado para aquele grande grupo pelas pessoas que coordenavam, que cuidavam né? Acho que cuidar é a palavra. Então, na verdade, uma das melhores formas de permitir essa abertura seja cuidar, e isso serve de reflexão até mesmo para as nossas práticas com crianças e, quem sabe, as [próprias] práticas educativas. Essa talvez seja uma grande lição que tenha ficado da capacitação. É a de que o cuidar abre portas. E esse cuidar pode, quem sabe, até ampliar a empatia ou iniciar a empatia por alguns temas. Talvez, algumas caras carrancudas não estivessem tão carrancudas depois de algum tempo. Então, eu penso um pouco nisso. Talvez algumas pessoas já se abram mais espontaneamente e outras não. Será que isso tem a ver com o sucesso ou insucesso das nossas modificações, o quanto as pessoas estão abertas para aquilo que se está propondo trabalhar?

Angela: Então, colocando essa ênfase especial na relação, na possibilidade de se vincular: cuidado e vínculo. Estamos falando o tempo todo de vínculo né?

S6: Eu estava pensando talvez numa coisa muito mais básica, sabe? Antes mesmo de a gente pensar em conquistar alguém, ou laço, pensar em como que a gente se apresenta e como que a gente se aproxima uns dos outros. Então, o modelo de capacitação parece ser fundamental, porque talvez o registro que tenha ficado tenha sido o de bem estar. E o bem estar nesse caso é uma variante muito importante.

Angela: E isso tem muito haver com o cuidado da criança, não?

S6: Sim. O bem estar como uma forma de criar raiz. E enraizar na memória o que fica dos encontros está muito associado a bem estar.

Angela: A associação que eu fiz foi com o bebê mesmo - a gente cuida de trocar fralda, dar de mamar, dar conforto - uma coisa de bem estar mesmo, de se sentir bem naquele ambiente. Avançando mais um pouquinho: já se passaram alguns anos desde quando nós fizemos o 'Janelas', em 2004. Sobre a sua experiência de educação e saúde, o que você desenvolveu de lá pra cá?

S6: Olha, logo depois da multiplicação, a gente começou a trabalhar com a viabilização da capacitação, que passava muito por sensibilizar os gestores sobre 
a sua importância. Então, mesmo que nós tivéssemos sido tocados pelo ideal do projeto, a primeira grande tarefa não era nem multiplicar, era obter condições para multiplicar. Havia uma série de questões político-administrativas difíceis de solucionar. Eu me lembro que havia alguns coordenadores de unidades de saúde que sequer admitiam as multiplicações em suas Unidades. Na verdade foram necessárias algumas batalhas para que houvesse liberação dos horários dos funcionários, disponibilização de espaço, etc. Era um grande desafio de saída, né? É como se, na verdade, você tivesse encontrado uma pérola ou um grande segredo - esse grande segredo de que os primeiros anos são para sempre - e tem a tarefa de disseminar esse segredo. Se fosse uma pérola teria que ser muito bem guardada e se fosse um segredo precisaria ser muito bem contado, né? Se é que poderíamos contar o segredo... Mas, logo depois dessa tarefa, nós fizemos a multiplicação para um número grande de agentes comunitários. Eu não vou saber ao certo, agora, o número exato, mas eu acredito que eram pelo menos uns 66 agentes comunitários.

\section{Angela: Só da Unidade onde você trabalhava?}

S6: Só da Unidade. Ao todo eram 120 pessoas. Eu me lembro que nós tínhamos condições de fazer as multiplicações para enfermeiros e médicos porque já havia uma reunião técnico-administrativa [que os reunia]. Os agentes comunitários, de certo modo, estavam mais disponíveis para encontros mais demorados. Eu me lembro de muitos momentos dessas multiplicações. A idéia era que nós contaminássemos as pessoas com a mesma energia que nós havíamos sido contaminados e que seria a [energia] de olhar as crianças em suas necessidades principais. Agora me ocorreu um dos momentos em que eu mais me surpreendi comigo mesmo! Quando a gente se interpelava, quando a gente avançava nas conversas, nas experimentações da multiplicação, geralmente os agentes comunitários nos devolviam situações muito dramáticas das crianças que viviam nos núcleos populacionais. Até aquele momento eu não havia sentido o gosto da desgraça da infância - brasileira e principalmente da periferia - que eles já começavam a anunciar. Então, eles contavam casos de abandono, violência, adoecimentos incabíveis, maus tratos, e tudo isso eclodia nas multiplicações. Eu me lembro que um dia... eu... eu... eu dei um grito, um grito no sentido de um berro mesmo. Foi um momento em que eu, olhando para todo aquele grupo, que era um grupo imenso, e extremamente impressionado com o que eu mesmo haveria de dizer, porque eu mesmo ainda não havia ouvido, eu pergunto: _'Mas, então, quem vai dizer às crianças que viver vale a pena?' $E$ ainda tem todo esse silêncio, porque, em situações muito hostis à vida, é muito difícil dizer a alguém que vale a pena a vida. Mas me lembro desse ponto de interrogação que eu carrego até hoje, vou carregar talvez pra sempre.

Angela: Esse vazio...

S6: Esse grito - Quem vai dizer às crianças que viver vale a pena?

Angela: Sim, mas houve um vazio na seqüência disto, pois que as pessoas não reagiram, não é? 
S6: Sim. Exatamente. Exatamente...

Angela: Como é que você entende isso?

S6: Eu entendo: _'Como eu vou apresentar o mundo à criança a partir de um lugar de tristeza, por exemplo, diante de condições inadequadas?

Angela: Condições daquelas pessoas todas?

S6: Eu acho que da realidade social. Eu acho que a gente vive tempos de muita violência, tempos de muita hostilidade, basta você ver as condições de moradia, as condições de emprego ou mesmo as condições de sobrevivência a que as pessoas estão submetidas nas periferias. Elas ainda [assim] conservam uma alegria que, na verdade para mim, é um grande instinto de sobrevivência. Mas, efetivamente, na hora em que a gente questiona se viver vale a pena, talvez a morte esteja muito presente nesse momento, a morte dos ideais, a morte da atenção social, a morte da igualdade, a morte da igualdade de oportunidades principalmente. Então, eu acredito que esse vazio, como você mesma colocou, permanece.

Angela: Uma experiência forte essa que você traz...

S6: Sim.

Angela: Você poderia falar mais dessa tua experiência de formação e, quem sabe, de outras que você tenha tido nesse período de 2004 pra cá?

S6: Talvez falar um pouquinho da continuidade do trabalho. Muitos agentes comunitários consideravam a idéia interessante, a grande maioria, mas tinham muitas dúvidas sobre como seriam recebidos e como seriam aceitos nas casas. Isso não foi uniforme: muitos fizeram meio que por obrigação, mas muitos compreenderam $o$ ideal do projeto e realmente se interessaram pelas crianças. $E$ tinham muitas, muitas devolutivas mesmo, do acompanhamento das crianças.

Angela: Você se lembra de alguma experiência muito significativa nesse sentido?

S6: Ah, sim, algumas, algumas. Eu me lembro, por exemplo, que a nossa própria equipe de saúde da família resolveu atender as crianças na própria comunidade. Havia um dia da semana em que nós nos deslocávamos diretamente para um salão cedido por uma das igrejas locais, porque isso facilitava o acesso de muitas mães ao atendimento. Nesse momento, nós fazíamos alguns itens da Puericultura, mas também criamos um espaço de brincadeira, e os agentes comunitários foram orientados a observarem como era esse brincar, como as crianças interagiam entre si. $E$, enquanto as crianças brincavam, os pais que compareciam ao local participavam de discussões sobre alguns capítulos da cartilha. Uma das coisas mais interessantes, mais dignas de nota nesse grupo de pais, foi a presença dos homens, a presença masculina, porque algumas mães trabalhavam fora e os pais traziam as crianças. E foram momentos muito, mas muito interessantes, porque pais e mães compartilhavam o momento do nascimento dos filhos, falavam de 
como foi o parto, falavam sobre alguma dificuldade na infância e, ao mesmo tempo, trocavam experiências. Nós, basicamente, conduzíamos, ah, coordenávamos o grupo. No começo eu mesmo fazia, mas depois passou a ser feito pelos próprios agentes comunitários. A idéia é que a gente treinasse a escuta pra fazer com que essa comunidade interagisse, pra que eles se conhecessem e, ao mesmo tempo, nós pudéssemos ver como as experiências eram ricas e as pessoas poderiam até se sensibilizar umas com as outras.

Angela: E isso ocorria? Freqüentemente?

S6: Sim. Sim!

Angela: Vê se eu entendi bem: no começo, os grupos de pais eram conduzidos pelo médico e enfermeiro - os agentes de saúde ficavam mais olhando, cuidando das crianças. Depois, eles aprenderam e bancaram facilitar o grupo de adultos, de cuidadores. É isso?

S6: Isso. Isso. É que, por uma questão do tempo que havia disponível, eu começava a atender as crianças, porque além das necessidades de Puericultura, elas também tinham necessidades médicas, clínicas. A partir de um dado momento do grupo, eu aproveitava para me retirar e passava para outra sala para iniciar esse atendimento. Neste momento específico é que existiram os momentos mais marcantes, na minha opinião, porque no primeiro momento a gente valoriza a queixa da mãe e corre o risco de ficar no modelo queixa e conduta mais uma vez, porém, o olhar sobre a criança parecia que começava a funcionar. Eu me lembro, por exemplo, de um garoto - não me lembro exatamente da idade dele - que entrou com a mãe e se agarrava nela e me olhava com um olhar muito distante. Durante a [minha] conversa com a mãe, eu olhava pra criança e percebia algo que não era ainda pra mim conhecido. Eu me lembro então que, como eu estava sentado de frente pra essa criança, eu apenas bati na minha perna e, pra minha surpresa, a criança pulou no meu colo!

Angela: É como se você a estivesse chamando com um gesto...

S6: Exato, como se eu a estivesse chamando e ela simplesmente pulou no meu colo!

Angela: E não era essa a sua intenção?

S6: Na verdade, era essa a intenção. Eu percebia algo que não sabia o que era, eu via aquele olhar distante, eu via aquela criança agarrada na mãe e de certo modo, instintivamente, eu pude chamá-la para o meu colo.

Angela: E ela respondeu!

S6: Ela respondeu. Mas, a história dessa criança é muito interessante para, talvez, poder compreender essa interação que houve. Ela havia presenciado, recentemente, o assassinato do pai, na sua porta, em uma das vielas, e ficado em estado de choque por muito tempo. Essa foi uma história que... 
Angela: Assassinato a tiro?

S6: Assassinato a tiro na frente dessa criança. Talvez eu tivesse compreendido o quanto essa criança precisava de suporte corporal, físico...

Angela: Você sabia desse fato?

S6: Não, não sabia.

Angela: Ah, não sabia quando chamou com o seu gesto?

S6: Não, eu fui saber depois. Esse é um dos quadros que mais me marcaram.

Angela: Você entende porque eu te perguntei isso? Se você chama pro seu colo uma criança que acabou de perder o pai dessa forma, e ela responde, deve estar sentindo uma falta imensa de pai, não é? E você não sabia disso...

S6: (risos) Não sabia. Depois eu fiquei sabendo. E aí, num segundo momento, eu me lembro que essa criança tinha a cabeça caída.

Angela: Como assim?

S6: A cabeça caía em direção ao peito, o queixo caído em direção ao peito, pescoço mole - e já era uma criança grande...

Angela: Grande como? Três ou quatro aninhos?

S6: Não, mais, cinco ou seis anos. E eu me lembro de ter massageado a nuca dessa criança enquanto ele estava sentado no [meu] colo, e eu continuava o atendimento normalmente conversando com a mãe. Mas, eu já tinha noção de que, quando ele se desse por satisfeito, ele mesmo sairia dali, daquele lugar. Eu também tinha o conhecimento de que tocar o pescoço [dele] seria voltar a empoderá-lo, dar-Ihe coluna, para que ele pudesse suportar qualquer sentimento que tivesse relação com as circunstâncias que eram muito deficientes. Eu vi essa criança outras vezes, mas não foi mais necessário ela pular no meu colo. Ele estava com a cabeça erguida e o pescoço no lugar, sendo capaz de interagir de outras formas.

Angela: Esta sua conduta clínica rompe um paradigma de atendimento médico...

S6: (risos)

Angela: É muito diferente ouvir a queixa da mãe, relacionando-se com a criança.

S6: Sim.

Angela: Neste caso de uma forma não verbal. Mas poderia ser verbal, uma situação em que você se relaciona com ambos - mãe e filho, pai e filho... 
S6: Sim. Aliás, observar essa interação passou a ser fundamental. Poder perguntar o que não está claro, poder perguntar mais: _'Por que a senhora se refere a ele deste jeito?'. Esclarecer, perguntar. Depois, no consultório, com a introdução da ficha, algumas perguntas passaram a fazer parte da consulta. E aí foi um sem número de informações que nós não teríamos como averiguar, salvo por acaso, a respeito da situação da criança. Descobrimos muitas crianças expostas às drogas, tanto nos bares quanto dentro de casa. Essa abordagem levava o nosso alerta em relação à saúde da criança; também fazia com que nós interagíssemos com os pais, numa tentativa de diálogo sobre os riscos que isso traria para a criança. $\mathrm{E}$, acredito que o relacionamento com essas crianças foi se modificando!

\section{Angela: Parece que não só com as crianças!}

S6: Ah, com toda a comunidade, né? Eu digo com as crianças porque, de um modo geral, as crianças apresentam um certo respeito ou mesmo medo da figura do médico. Mas, eu me lembro de inúmeros casos que, antes mesmo de eu pegar a espátula para examinar a garganta da criança, ela já oferecer a boca aberta, talvez, por ter um pouco mais de confiança no relacionamento; ou mesmo [as crianças] nos procurarem em horários improváveis de consulta, podendo ser atendidos porque já havia um vínculo estabelecido. Mas eu acredito que o mais marcante tenha sido mesmo esses grupos na comunidade e essas crianças atendidas. Você gostaria de conhecer outro caso?

Angela: Sim, claro! Mas antes, deixa eu entender uma coisinha: você falou daquela dinâmica de trabalho com a comunidade onde vocês faziam os grupos de pais e de crianças. Se eu entendi bem, quando você saía para fazer as consultas, os agentes faziam os grupos? É isso?

S6: Sim.

Angela: E depois você acompanhava e discutia o trabalho com eles?

S6: Sim!

Angela: Era uma experiência significativa?

S6: Sim.

\section{Angela: Por quê?}

S6: Era significativo porque estavam presentes todos os agentes comunitários e um auxiliar de enfermagem. E nós trocávamos informações que variavam desde o peso, a estatura, até se a mãe falta muito à consulta ou não, passando pelo contexto familiar e as necessidades médicas propriamente ditas. Então, cada um trazia o seu olhar e nós sempre conseguíamos observar as crianças que estavam com maior risco. Se a enfermeira não estava presente [em uma reunião como essa], depois ela também ficava sabendo qual era o foco da atenção. Então, era muito significativo... 
Angela: É, devia instrumentalizar muito todo o mundo, não é?

S6: Isso.

Angela: Porque, se cada um faz uma parte e depois troca, se você vai para a atividade clínica, mas o agente de saúde se sente competente e capaz de facilitar um grupo de pais para, depois, vocês discutirem, enfim, isso deve fortalecer muito, desenvolver as pessoas.

S6: Sim.

Angela: E o outro caso que você ia contar?

S6: Mais uma vez eu não me lembro da idade da criança, talvez ela tivesse mais de seis anos, eu não me lembro exatamente...

Angela: Mas era uma criança. (risos)

S6: (risos) Sim, era uma criança. O que mais me chamou a atenção é que esse caso foi atendido nesse grupo. Tratava-se de uma criança que era neta de uma senhora que eu havia atendido - essa avó teve uma complicação muito séria de uma doença muito comum e veio a falecer. Mas, o processo de morte dela foi muito lento. Na verdade, ela teve, primeiro, complicações agudas; nós, da unidade de saúde, fomos fundamentais para o diagnóstico, mesmo que ela estivesse internada. Ela saiu do hospital depois de complicações neurológicas, dermatológicas, circulatórias, saiu sem seqüelas. Na época, nós diagnosticamos uma depressão, começamos a tratar, mas muito pouco tempo depois ela desenvolveu uma leucemia aguda e grave e de rapidíssima evolução. Durante esse período, nós sabíamos que não havia muitas alternativas terapêuticas pra ela e nós nos lembramos de como as crianças estavam em relação a esse caso. Eu me lembro de ter feito algumas visitas nesse sentido, buscando atender a doente que se mostrava um doente terminal, mas sem perder de vista um olhar sobre as crianças, que eram duas - uma era pré-adolescente e a outra menor. A coisa que mais me chamou a atenção é que pouco tempo depois do falecimento dessa senhora, a criança menor foi ao grupo com enurese noturna, que ela não apresentava antes. Antes de atender essa criança, eu sugeri ao agente comunitário que fornecesse lápis e papel para ela e, então, a criança fez um desenho, um desenho dela com a avó. Quando a criança entrou na consulta, em que a gente avalia a parte clínica, ela me trouxe o tal desenho. Então, foi possível abordar a tristeza que ela estava sentindo. De qualquer modo, a enurese cessou e não havia indícios de que ela tivesse outros comprometimentos orgânicos.

Angela: Não poderia ser de causa neurológica...

S6: Não, nem mesmo de um quadro infeccioso. Ela e sua família foram ao grupo em busca de ajuda. Eu imagino que se não estivéssemos atentos ao luto que essa criança estava vivendo e se não pudéssemos externar a nossa preocupação em relação a esse luto, talvez ela não pudesse vivenciar a sua tristeza com a força 
que uma criança tem de se recuperar - com a sua resiliência - e se reconstituir. Em pouquíssimo tempo já não havia mais a queixa.

Angela: Esses dois casos que você relatou têm em comum uma experiência subjetiva, emocional forte. Além dessa qualidade psicológica, emocional, eu também estou interessada em identificar outras questões de natureza mais social. Você poderia falar de alguma experiência que te marcou, alguma coisa desse outro tipo, com esta outra qualidade?

S6: Olha, os aspectos psicológicos, emocionais, sociais, culturais, eles estão presentes no processo de saúde e doença. Porém, reconhecê-los, às vezes chega a ser terapêutico. A questão é: _'Que remédio eu dou para uma criança com enurese noturna? Ou, que medicamento eu dou para uma criança que está triste porque perdeu o pai assassinado?'. Só de não medicar uma criança, eu acho um avanço! (risos). É possível que alguém dissesse que precisasse de um antidepressivo para uma ou precisasse de uma medicação específica para enurese para a outra [criança], mas, efetivamente, o reconhecimento desses aspectos pode ser fundamental. Mas, voltando à questão dos aspectos sociais, eu me lembro de... (silêncio) Está me vindo à memória um caso de duas crianças muito pequenas - elas já engatinhavam - com idades bem aproximadas, eram irmãs, e mãe as deixava freqüentemente sozinhas em casa, e elas se alimentavam do que encontravam dentro da casa, inclusive de alimentos apodrecidos, como cascas de banana, cascas de frutas apodrecidas.

Angela: Elas apenas engatinhavam?

S6: Elas não andavam porque elas eram desnutridas. Eram crianças um pouco maiorzinhas, que eu tive a oportunidade de atender no grupo e constatar que elas estavam desnutridas mesmo.

Angela: Quer dizer que era um caso grave de desnutrição?

S6: Sim, desnutrição. E a mãe as abandonava em casa, costumava sair, se eu não me engano, para a região central de São Paulo para o consumo de drogas. E eu me lembro que uma das vizinhas chegou no nosso grupo dizendo: _'Olha, eu não agüento mais ver essas crianças desse jeito e eu trouxe as crianças!'. Naquele momento eu senti que o nosso papel era apoiar a atitude dela e fazer nossa a indignação dela. Como equipe, nós conseguimos fazer isso porque começamos imediatamente a ver quais recursos seriam possíveis para essa situação. E eu me lembro que a nossa primeira atitude foi dar suporte para essa vizinha. Então, nós fomos em busca de trabalho [para ela] porque ela já tinha filhos e o salário do marido não era suficiente para que ela acolhesse mais duas crianças - esse foi um dos primeiros movimentos que nós fizemos. Depois, acionamos o conselho tutelar. Lembro de ter visto as crianças no grupo mais uma vez e foi possível fazer desde a coleta de exames até o tratamento empírico para verminose, a introdução de complexos polivitamínicos. Elas eram crianças muito carentes, elas ficavam no meu colo aninhadas como... Acho que ninguém conseguiria tirá-las de lá! (risos) Só com muito esforço. 
Angela: Você lembra qual foi o final dessa história?

S6: Olha, eu me lembro que vi as crianças mais vezes e em melhor estado, que depois o agente comunitário continuou acompanhando o caso, mas eu não me lembro o que foi feito da mãe, nem qual foi a ação do conselho tutelar.

Angela: Elas teriam ficado com essa nova família?

S6: Eu fico com essa idéia...

Angela: É, é um caso onde essas questões sociais são determinantes da saúde física, mental, não é? Mas mudando o foco para a sua formação pós-janelas, você teve outras experiências, como educando ou como educador, para me contar?

S6: Qualquer curso ao longo desse tempo?

Angela: Sim, e que você considerou uma experiência marcante, uma experiência interessante, e por quê?

S6: Olha, eu acabei fazendo algumas coisas na área de gestão e trabalhos com cursos, às vezes com multiplicação, mas nada tão interessante. Na verdade, mais com conteúdos informativos. Trabalhar talvez com a área de práticas corporais integrativas tenha sido uma experiência um pouco mais interessante.

Angela: Você faz esse tipo de formação, não é?

S6: Sim. Eu me lembro de ter trabalhado um pouco com Liang Gong, a ponto de ter estabelecido um grupo na comunidade - era um grupo freqüentado por muitas pessoas da comunidade - e também um curso de Dao Yin Bao Xiang Gong.

Angela: O que é?

S6: É um tipo de ginástica oriental.

Angela: Mas aí você recebeu formação para trabalhar com isso na comunidade?

S6: No caso do Liang Gong, sim; do Dao Yin não, [porque] eu ia mais como interessado.

Angela: E para multiplicar, formar outras pessoas?

S6: Não, não me lembro agora.

Angela: Então, dá pra dizer que você não teve uma experiência similar nesse período?

S6: Não, não tive.

Angela: Parece ser cada vez mais raro esse tipo de formação, não é? 
S6: O que mais se aproxima é uma formação específica para psicoterapeutas corporais, mas aí é porque o conteúdo é mais vivencial.

Angela: E por iniciativa tua, particular, não no âmbito das políticas públicas?

S6: Não no âmbito das políticas, lamentavelmente podemos dizer que aquele tempo era bom e a gente não sabia. (risos)

Angela: (risos) É... Valeu! Terminamos. Obrigada. 